
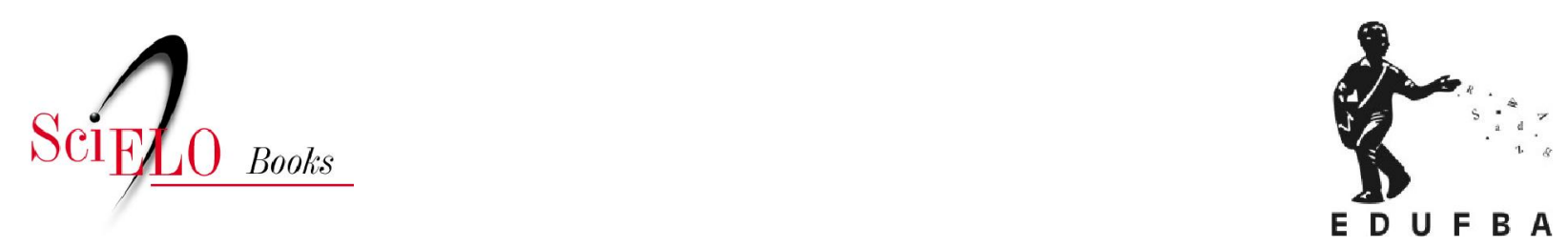

\title{
Infância afrodescendente
}

epistemologia crítica no ensino fundamental

Ana Katia Alves dos Santos

SciELO Books / SciELO Livros / SciELO Libros

SANTOS, AKA. Infância e afrodescendente: epistemologia crítica no ensino fundamental [online]. Salvador : Editora EDUFBA, 2006. 165 p. ISBN 978-85-232-0900-1. Available from SciELO Books $<$ http://books.scielo.org $>$.

\section{(c)}

All the contents of this chapter, except where otherwise noted, is licensed under a Creative Commons Attribution-Non Commercial-ShareAlike 3.0 Unported.

Todo o conteúdo deste capítulo, exceto quando houver ressalva, é publicado sob a licença Creative Commons Atribuição - Uso Não Comercial - Partilha nos Mesmos Termos 3.0 Não adaptada.

Todo el contenido de este capítulo, excepto donde se indique lo contrario, está bajo licencia de la licencia Creative Commons Reconocimento-NoComercial-Compartirlgual 3.0 Unported. 
InfÂnCIA Afrodescendente:

EPISTEMologia CRítica no Ensino Fundamental 


\title{
果 \\ Universidade Federal da Bahia
}

\author{
Reitor \\ Naomar de Almeida Filho \\ Vice Reitor \\ Francisco José Gomes Mesquita
}

\section{Editora da Universidade Federal da Bahia}

\section{Diretora}

Flávia M. Garcia Rosa

Conselho Editorial

Angelo Szaniecki Perret Serpa

Carmen Fontes Teixeira

Dante Eustachio Lucchesi Ramacciotti

Fernando da Rocha Peres

Maria Vidal de Negreiros Camargo

Sérgio Coelho Borges Farias

\section{Suplentes}

Bouzid Izerrougene

Cleise Furtado Mendes

José Fernandes Silva Andrade

Nancy Elizabeth Odonne

Olival Freire Júnior

Sílvia Lúcia Ferreira 


\title{
Ana Katia Alves dos Santos
}

\section{INFÂNCIA AFrodESCENDENTE: EPistemologia Crítica no Ensino Fundamental}

\author{
Salvador - Bahia


Copyright (C) 2006 by Ana Katia Alves dos Santos

\author{
Projeto Gráfico, Capa e Editoração Eletrônica \\ Carlos Henrique de Jesus
}

Digitaç̃̃o

Ana Katia Alves dos Santos

REVISÃo E NoRMaLIZAÇão

Maria José Bacelar Guimarães

Biblioteca Central Reitor Macêdo Costa - UFBA

S237 Santos, Ana Katia Alves dos.

Infância e afrodescendente : epistemologia crítica no ensino fundamental/

Ana Kátia Alves dos Santos. - Salvador : EDUFBA, 2006.

$165 \mathrm{p}$.

Inclui anexos.

Inclui bibliografia.

ISBN 85-232-0385-0

1. Crianças negras - Educação - Bahia. 2. Negros - Educação - Bahia.

3. Educação de crianças - Bahia. 4. Epistemologia. 5. Ensino fundamental-

Bahia. I. Título.

$$
\begin{aligned}
& \text { CDU - } 373.3(813.8) \\
& \text { CDD - 372.98142 }
\end{aligned}
$$

EDUFBA

Rua Barão de Geremoabo, s/n

Campus de Ondina

40170-115 Salvador Bahia

telefax (71) 32636160

www.edufba.ufba.br

www.edufba@ufba.br 


\section{$A$}

Antonio Osvaldo (in memoria) e Antonieta, pais queridos, por me ensinarem o respeito e o amor pela vida.

Minhas irmãs, membros do Ilê Axé Oxumarê: Osvaldina (in memoria), Ana Rita (ambas Ebômin) e Josenilda (Ekédi), além de Ana Lúcia (Abiã) do Ilê Axé Iyá Nassô Oká (Casa Branca), pelos diálogos e ensinamentos pautados na tradição religiosa de descendência africana.

Crianças, ex-educandos(as), sobrinhos(as) e afilhados (Benedict Antonio e Irlan), sem os quais não compreenderia o quão importante é o processo educativo.

Educadores e educadoras do ensino fundamental, alunos(as) e exalunos(as) do ensino superior, pelos momentos singulares de troca e re-significação permanente de conhecimento. 



\section{AgradeCIMENTOS}

s agradecimentos traduzem-se aqui como reconhecimento de co-autoria desta obra, visto que, num sentido amplo, todas as pessoas citadas, de certa forma, deixaram "um pedaço de si" que foi incorporado ao meu discurso e elaboração de pensamento. Reconheço, assim, a dinâmica na produção de conhecimento e valorizo a participação "do outro", que me possibilitou olhares multiplicados.

Ao Professsor Dr. Dante Galeffi, orientador do doutorado, pelo belíssimo prefácio escrito para esta obra, bem como pelos ensinamentos e possibilidades infindas de diálogo.

À Professora Dra. Joseania Miranda Freitas, orientadora do mestrado, sempre muito tranqüila, portadora de uma atitude ética admirável, pela orientação presente e preocupada, e por acreditar nesta proposta de investigação.

À Professora Mestra Nilda Moreira Santos, professora da UCSAL, ex-professora da graduação, por ter me ensinado a natureza crítica do conhecimento em suas maravilhosas aulas na disciplina Currículo.

Ao professor Felippe Serpa (in memoria), por sua postura, forma de vida autêntica, desimpedida, ensinando na prática, pelas relações, a necessidade de nos tornarmos, como educandos/educado- 
res e pessoas, cada vez mais livres das dominações sócio-políticas e econômicas.

Aos amigos Wendel e Gilson, por se fazerem sempre presentes no meu processo de produção de conhecimento. Agradeço também a Gilca, Milton, Jeferson, Silvana, Albérico, Telma, Edméa e Valéria pelos incentivos e contribuições de potencial reflexivo. Vocês foram fundamentais neste processo.

Ao Ilê Axé Oxumarê (terreiro de Candomblé localizado na Avenida Vasco da Gama, Salvador/BA) e aos professores, diretora, secretário e crianças da escola do Lobato (Salvador/BA). A abertura, a receptividade e a colaboração de todos foram aspectos fundamentais para o caminhar desta reflexão. Consegui me sentir membro dessas comunidades, vocês souberam me acolher. Sou grata por isso! 


\section{PREFACIO}

nfância Afrodescendente: Epistemologia Crítica no Ensino Fundamental. Com este tema, Ana Katia reuniu as principais dimensões de sua investigação: Ciência da Educação na Bahia, Infância Afrodescendente, Epistemologia Crítica e Ensino Fundamental. Quero dizer, seu objeto investigativo é um campo de sentido e significação que congrega uma constelação compreensiva de comum-pertencimento entre Ciência, Infância, Afrodescendência e Ensino Fundamental.

O caminho percorrido é de uma felicidade incomum. Tudo nele fala do mesmo sentido do comum-pertencimento de ser-humano-mundo e natureza. Preciso, claro, compassivo, denunciador, consistente é o discurso construído por Ana Katia em sua saga poética e restauradora. De repente, a época do abandono e da carência se vê desfeita pela beleza e rigor de um gesto simples e direto, um acontecer outro que não é mais da época da desconstrução. Lançada em uma jorrância utópica, no sentido próprio do termo, Ana Katia realiza uma abertura inaugural com sua origem primeva, ofertando seu dom à transposição do estado de indigência do afrodescendente para o estado de plenitude de sua diferença. Crítica e solução se aliam na configuração de uma Ciência do Educar, uma Epistemologia Crítica, cujo ethos emana da compreensão integradora de ser-humano-natureza. O que ela chama de Epistemologia Crítica é um ato fundador de um fazer científico re- 
significado em sua ontologia. O horizonte compreensivo de Ana Katia se ramifica e se espalha na compreensão ontológica e préontológica dos fenômenos.

Ora, fenômeno é sempre o aparecer de algo para alguém. Fenômeno é acontecimento do ser-sendo. Quero dizer, ela não tomou a atitude fenomenológica como uma mera figura de linguagem e nem muito menos como um "método" imitativo das ciências ditas positivas ou objetivas. De forma pertinente e direta, ela seguiu o sentido próprio e apropriado de um exercício fenomenológico radical, articulando a atitude aí implicada com o universo afrodescendente em sua essencialidade de inteireza e plenitude livres de sujeições e exclusões ideológicas. De onde provém esta força compreensiva que a tudo une em sua passagem e morada?

Fico perguntando acerca do mistério do aparecer do sentido-sendo em sua plenitude, e re-descubro a origem comum de tudo. A comunidade de sentido pertence a conjuntura do simples. Assim, o jogo de exclusões e centralidades hegemônicas é um traço histórico da dominação planetária fundada na fragmentação e separatividade. Bem analisada, a dominação própria da racionalidade moderna européia não anula e nunca anulou o mistério do ser vivente em suas múltiplas florações.

De forma própria e apropriada, Ana Katia des-velou, em consonância com a sua ancestralidade, o princípio ontológico do comum-pertencimento de tudo, a partir de uma "procura ciente" transformada em "investigação" em que o "questionado" é "determinado de maneira libertadora", sem nunca abandonar o lócus espiritual de sua filo e ontogenia. Isto é a expressão de uma radical revolução compreensiva do ser-no-mundo-com, em que as forças arcaicas e ancestrais se renovam na florescência do que se doa na conjugação da temporalidade instante. Aí o cuidar é a palavra-vida. Um modo de ser para além dos territórios da racionalidade instituída e imperante, um modo de ser afrodescendente: uma diferença libertadora. 
Diferentemente da profecia em que o poeta dionisíaco Zaratustra anuncia a "morte de Deus", Ana Katia parece profetizar justamente o "renascimento da divindade" no coração ciente da humanidade. A virada epistemológica cumprida reconcilia o ato de origem com o sentido próprio do fazer ciência. Nesta medida, se o Zaratustra de Nietzsche configura o desespero do homem moderno diante de suas próprias armadilhas racionais, e nesta mesma direção, a hermenêutica fundamental de Heidegger denuncia o "esquecimento do ser", por razões históricas muito próprias do ciclo historial do Ocidente, ambos não podem profetizar senão a "morte de Deus" e a "morte da metafísica", pois permanecem encravados no emaranhado da racionalidade eurocênctrica, apesar de terem realizado uma saída ontológica que deu e dá a pensar no além homem monológico. Entretanto, eles mesmos não poderiam profetizar o "renascimento do divino".

Tudo isso para dizer: Ana Katia pode falar do renascimento do divino no coração da humanidade porque o seu fundamento ontológico é afrodescendente. Indiscutivelmente, isto é uma dádiva para todos os que para ele se abrirem. Por que devemos insistir na desolação e no niilismo da racionalidade imperante? Será que bebendo das fontes primevas seremos capazes de nos libertar do desamor avassalador? E por quê haveríamos de buscar nossa dignidade ontológica na tecnociência insana e maquínica, desumana e alienante?

A virada epistemológica apresentada por Ana Katia reúne a força necessária para configurar uma educação infantil afrodescendente fundada em princípios emanados da simbólica dos orixás. Os mesmos são extraordinariamente universais e organizadores de um ethos cosmocêntrico capaz de iluminar a saga de uma humanidade além do homem da razão instrumental e monológica.

O percurso epistemológico realizado por Ana Katia mostra, com apuro e rigor, uma alternativa que reúne os princípios 
da reconciliação, integração, novos padrões de convivência, compartilhamento, criação, co-responsabilidade, multiplicidade, diversidade da vida, rigor simples e delicado, força, inteligência, justiça, acolhimento e respeito à natureza. Tais princípios são suficientemente universais para comporem uma educação da infância dos afrodescendentes constituída a partir de uma atitude de absoluta unidade de corpo e mente. Isto, então, tem a dizer a todos nós, na medida em que somos todos responsáveis pelos desígnios do mundo globalizado.

Sei que o que estou dizendo se mostra extemporâneo, inatual, no sentido da temporalidade não domada pela racionalidade, e sei como a própria Ana Katia se sente diante de tamanha inflexão implicada. Assim é até melhor, porque se preserva o acontecimento de seu indevido desvio. Quero desejar para Ana Katia toda a proteção e axé dos orixás, de maneira que a sua simplicidade permaneça perfurando as barreiras do tempo psicológico da centralidade racial dos de cor branca. A simplicidade é a marca dos que pisam com firmeza e se lançam duráveis na passagem do tempo. A forma correta, abundante e atenciosa de seu texto é a expressão mais concreta de um ato co-criador que se conjuga à força do tempo dos ancestrais e se enfutura na agoridade do presente vivo como afirmação do fluir incessante que não conhece ocaso.

Agradeço a oportunidade de compartilhar da aventura de conceber e realizar uma educação fundamental que atente para os princípios antes citados, e que promova a constituição de seres humanos abertos ao aprendizado multifacetado e sempre "misterioso" do ser-mundo, na dinâmica existencial e simbólica da sabedoria afrodescendente.

Parabenizo, assim, Ana Katia, pelo singular trabalho apresentado, almejando que o que nele se encontra apenas esboçado como abertura para o modo de ser afrodescendente possa tornar-se caminho fecundo para uma revolução que possua a grandeza de poder 
congregar em um mesmo âmbito a potência humana multiplicada em suas mais diversas moradas e modos genuínos de ser-com.

Por fim devo dizer que não tenho nenhuma questão que comprometa a integridade da obra. Desejo, também, que a mesma possa ser amplamente divulgada, porque, além de teorizar diligentemente sobre o tema da infância afrodescendente, apresenta uma crítica apurada e consistente ao modo de ser do professor educado no regime monológico da razão instrumental, prospectando possibilidades curriculares ainda impensadas. Parabéns pelo trabalho e pela coerência com a vida-vivente.

\section{Dante Augusto Galeffi}

Dr. em Filosofia da Educação e Coordenador da linha de pesquisa Filosofia, Linguagem e Práxis Pedagógica, do

Programa de Pós-graduação em Educação da

Universidade Federal da Bahia 



\section{SUMÁRIO}

\section{INTRODUÇÃO}

O QUE É ISTO-A INFÂNCIA?.

1.1 CONCEPÇÃO NATURAL DE INFÂNCIA......................29

1.2 CONCEPÇÃO HISTÓRICA DE INFÂNCIA E O CONTEXTO BRASILEIRO

1.2.1 A infância de origem afrodescendente..............................39

1.2.1.1 Princípios fundadores da infância afrodescendente..............48

1.2.1.2 Infância afrodescendente: sujeito de direitos?

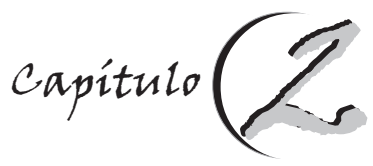

EPISTEMOLOGIA, EDUCAÇÃO E INFÂNCIA AFRODESCENDENTE NO HORIZONTE DA CONTEMPORANEIDADE.

2.1 BARREIRAS PARA A CONCRETIZAÇÃO DE

UMA EPISTEMOLOGIA CRÍTICA NO

ENSINO FUNDAMENTAL 


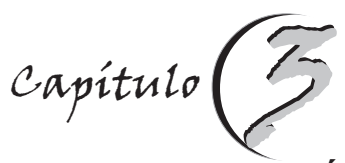

HISTÓRIA E CIENTIFICIDADE DO ENSINO

FUNDAMENTAL: HÁ LUGAR PARA A

DIFERENÇA NA ESCOLA QUE FAZEMOS?

3.1 ESCOLA DA PRESENÇA E

DA SOLIDARIEDADE

UMA PROPOSTA COMO CONCLUSÃO:

ENTRE EPISTEMOLOGIA E TRADIÇÃO

AFRODESCENDENTE

REFERÊNCIAS

BIBLIOGRAFIA RECOMENDADA.

GLOSSÁRIO

ANEXO A - MITOLOGIA

AFRO-BRASILEIRA/A ORIGEM DO MUNDO........159 


\section{INTRODUÇÃO}

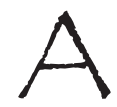

produção de conhecimento da criança de origem afrodescendente tem se constituído em objeto de preocupações fecundas, principalmente porque, neste milênio, emerge a necessidade urgente de revisar o projeto da racionalidade moderna, a fim de (des)construir alguns de seus imperativos. A razão cognitivo-instrumental, o homem da objetividade, a lógica das verdades absolutas e esmagadoras a favor do adulto branco-europeu, a separação homem-natureza são algumas dimensões que justificaram e legitimaram a modernidade e os seus processos de exclusão, negação e silenciamentos.

Tomando este contexto e considerando, principalmente, o processo de formação (colonização) do Brasil, em sua configuração moderno/ocidental, como eixo disparador da "racionalidade" brasileira atual, esta obra analisa, intencionalmente, o conhecimento produzido pela infância afrodescendente situada no ensino fundamental baiano. A discussão circundante é a Ciência da Educação e a conseqüente epistemologia do educador.

A construção do pensamento científico moderno traz significativas influências para a educação, principalmente a partir do pensamento cartesiano, ao instituir a separação sujeito/objeto. $\mathrm{O}$ projeto epistemológico da modernidade, formulado entre os séculos XV e XVIII, coincidente com a criação de raízes européias em terras 
brasileiras (a partir da metade do século XVI), põe o sujeito numa relação de superioridade frente ao objeto. Esta relação é repensada neste texto, visto que a inspiração de fundo, de natureza fenomenológica, é a ontologia "proposta" por Martim Heidegger (sem fechar nesta única possibilidade) e suas relações com os princípios organizadores das comunidades religiosas de tradição africana. Retomamos, então, a clássica questão, posta desde a teoria do conhecimento cartesiana: a relação sujeito/objeto; a separação homem/mundo.

A fenomenologia questiona esta dicotomia, afirmando que qualquer consciência é intencional e, portanto, não há pura consciência. A consciência visa o mundo e, deste modo, não há objeto em si, ou seja, não há objeto independente da consciência que o percebe. O objeto, como fenômeno, é algo que aparece para uma dada consciência. O conceito de intencionalidade é aqui pontual, pois indica essa singularidade da consciência, que tem consciência de alguma coisa. Por isso, não há fatos com a objetividade tão pretendida pelo positivismo, já que o mundo não é em si; ele é para mim. Ou seja, não percebemos o mundo como um dado puramente objetivo, porque o sentido atribuído e as significações que circundam este mundo já desmontam a objetividade pretendida. Enquanto método e filosofia, a fenomenologia tece críticas à filosofia tradicional que elabora um pensamento metafísico, no qual a idéia de ser é vazia e abstrata, voltada para a explicação. Ela busca encontrar o sentido do Ser na experiência humana, na situação concreta.

As reflexões iniciais que estruturaram esta obra partiram do posicionamento político/pedagógico impulsionado pela nossa experiência como docente de grupo infantil por mais de dez anos. A percepção de que as crianças que cultuam valores de tradição afrodescendente, quando chegam à escola, na maioria das vezes, acabam por "se enquadrar" a um processo de construção de subjetividade que se converte em ideologia, mobiliza-nos para tentar 
re-significar a ciência da educação, pondo em dúvida a compreensão de ciência que elaboramos como educadores, a partir da análise de seus principais fundamentos. A busca é, então, por uma resignificação dos modos de produção de ciência no contexto escolar baiano e brasileiro, de forma ampla.

O modo de pensamento elaborado pelas crianças afrodescendentes, no contexto escolar, configura-se em saber produzido a partir de certos interesses e fechado para amplos aspectos da realidade; ou seja, é instituída uma relação cindida entre elas e o mundo vivido fora da escola (tal qual o princípio cartesiano). Os aspectos étnicos e culturais participantes da vida dessas crianças são negados, silenciados ou negligenciados na escola. Lévi-Strauss (1976) corrobora esta idéia, quando afirma que se o sujeito está privado da realidade, ele se situa numa condição de "fantasma ou aparição social", já que todo ser humano precisa se sentir integrado ao seu contexto, ao seu mundo. Isto é o que não ocorre na escola, em relação às crianças afrodescendentes.

A escola ainda cultua uma racionalidade moderno-colonialista, portanto branco-ocidental e cartesiana, para pensar os sujeitos e o conhecimento que eles produzem. Infelizmente, não é possível falar dessa história como se ela pertencesse apenas a um passado extemporâneo, visto que ela ainda se faz firmemente presente. Mas, se é certo, como diz Santos (1996, p.23), citando Marx, que "Tudo que é sólido se desfaz no ar", é possível pensar e buscar mobilização para a construção de alternativas de ciência e de educação. Estas alternativas não devem partir de negações étnicas (seja ela negra, indígena, cigana...), sociais, religiosas, culturais, mas, ao contrário, devem tomar essas diferenças como riqueza e caminho facilitador na construção da "humanidade perdida" em educadores e educandos.

Superar a política da desvalorização étnica, impulsionada pelo corte realizado entre sujeito e experiência, buscando uma nova 
consciência em educação, é um dos desafios postos para a escola contemporânea na Bahia e no mundo. Esta desvalorização apresentase de várias formas: nas imagens selecionadas para "decoração", nas atividades e em alguns discursos etnocêntricos dos adultos (e de outras crianças). Cultuar valores diferentes dos valores hegemonicamente eleitos, neste caso os afrodescendentes, é marginal. Exemplos disto foram observados em sala de aula. A professora diz: "Nós somos filhos de Deus, e... [cita nome de criança iniciada no Candomblé] é filho de quem?" sala com um boneco de papel marrom é muito feio; alguns professores distribuíam o lápis rosa para pintar a pele de um bonequinho na atividade, porque cor de pele é rosa (geralmente a desvalorização étnica começa pela cor da pele).

Essas e outras situações nos mobilizam no sentido de considerarmos a urgência de discutirmos e propormos outras possibilidades de pensarmos o conhecimento que vem sendo valorizado na escola fundamental e as conseqüências dele para a formação infantil de origem afrodescendente.

Pensamos que uma Epistemologia ${ }^{2}$ Crítica, re-significada em seus fundamentos, precisa se efetivar no cenário escolar fundamental do Estado da Bahia e nos demais espaços/estados brasileiros abertos à diversidade e à realidade multifacetada. Uma epistemologia que valorize a afrodescendência como viés de pensamento, como acolhimento crítico, como angústia que educa e ensina a nos predispormos à possibilidade de sermos, talvez, o outro diferente do instituído.

A nossa implicação com essa epistemologia é dupla, na medida em que nos formamos nessa escola da desvalorização étnica e cultural e nela somos docentes. A reflexão sobre a Infância Afrodescendente: e a Epistemologia Crítica no Ensino Fundamental mobiliza-nos no sentido de definir esta obra como um ato não neutro, intencional, politicamente situado, integrado com o nosso contexto de vida e de 
atuação profissional, rebelde, porque não é conformado com o que está posto no cotidiano escolar.

Enfim, as indagações são cada vez mais freqüentes e inquietantes e nos impulsionam a continuar aprofundando estas reflexões, que não devem se esgotar com a escrita deste livro. Acreditamos que o enfrentamento desse desafio é também em favor de muitas crianças e educadores, alguns co-parceiros desta reflexão. Tornar público, coletivizar, colaborar com esses dois grupos sociais e perceber as mudanças se operando no cotidiano, a partir da escola, é um sonho possível.

Este texto tenciona ainda dirigir um outro olhar para as crianças, estes seres que, na modernidade, foram discriminados, negados, excluídos, sem vez nem voz, devido ao adultocentrismo radical que ignora o mundo idiossincrático da infância.

As crianças afrodescendentes precisam produzir conhecimento no qual se vejam refletidas, para que possam se expressar com mais autenticidade. As questões relacionadas com a vida e a cultura de sua etnia devem fazer parte de sua formação como seres humanos, para que possam compreender, crítica, interativa e conflitivamente, quem é o outro e de que forma esse outro também se constitui como ser humano. Isto, entretanto, não deve significar a negação de um deles. Nessa perspectiva, o conceito de alteridade será útil para a compreensão do que é ser culturalmente afrodescendente, num espaço que privilegia um "outro" diferente dele. A Escola deve repensar o que faz com essas crianças e que lugar lhes confere no processo social.

A exclusão e o silenciamento da cultura afrodescendente no cenário escolar apresenta-se de várias formas. Uma delas, como consideramos anteriormente, é a ausência de representação dos valores, crenças e conhecimentos da criança afrodescendente nos materiais e nas práticas escolares (textos escritos, orais...). O máximo que podemos perceber é o uso forçoso de imagens estereotipadas e 
discussões acerca dessa cultura como folclore, com pouca ou nenhuma leitura crítica, a fim de justificar a "pluralidade cultural" defendida pelos Parâmetros Curriculares Nacionais.

A política de sentido, implícita nos espaços escolares, fortalece o império da cultura moderno-colonialista, por isso brancoocidental, nas defesas e compreensão acerca do que é ser humano e de que produções devem ser valorizadas e/ou excluídas. Neste sentido, o que ocorre com a criança afrodescendente é a sua não promoção social, desvalorização da sua descendência africana e incorporação, como habitus $^{3}$, de um comportamento de ajustamento interior e subjetivo às condições objetivas determinadas na exterioridade. Ou seja, ao chegarem à Escola, as crianças afrodescendentes iniciam o processo de ajustamento ao universo de racionalidade branco-ocidental que ainda edifica o cotidiano contemporâneo das escolas de Ensino Fundamental.

A incorporação desse habitus vai colaborar com o conhecimento a ser produzido por essas crianças. Isso ocorre porque lhes é negada a possibilidade de vivenciarem as suas próprias experiências. Deste modo, como produtoras de habitus, elas não transcendem o posicionado. A essas crianças deve ser possibilitado, através da epistemologia valorizada pelo educador, transcender a ideologia revelada na instituição escolar, que obscurece as suas existências. Daí, neste texto, tornarem-se explícitas as diferenças entre representações sociais e ontologia afrodescendente (inspirada também na ontologia heideggeriana), a fim de possibilitar a reflexão sobre uma epistemologia re-significada (do projeto cartesiano à epistemologia crítica). Quais os fundamentos, ou princípios, de uma epistemologia crítica preocupada com a valorização étnica da criança afrodescendente? Esta é a principal questão que movimenta as reflexões aqui explicitadas.

Essa questão está também relacionada com as epistemologias já eleitas como orientadoras da produção de conhecimento do 
educando e das práticas pedagógicas do Ensino Fundamental na contemporaneidade. Entendemos que a epistemologia genética, atualmente interpretada por grande parte dos educadores, nos espaços educativos, como "verdade absoluta" colabora para uma compreensão acerca das crianças como seres "universais", biologicamente iguais, fechados para a multiplicidade da realidade do cotidiano. A idéia de "igualdade" humana, implicitamente colocada nessa interpretação, acaba sendo usada como defesa organizadora oculta para a não consideração das demais dimensões da formação do ser humano, dentre elas a étnica. Se somos todos biologicamente iguais, é secundário ou desnecessário valorizar a formação histórica, cultural, política, social, étnica, mítica. Há um silenciamento relativo a essas questões no âmbito do Ensino Fundamental. Quando essa discussão vem à tona, é no sentido de situar o afrodescendente, o negro (ou o índio, o cigano...) como componente de culturas folclóricas, "currículo turístico" nas palavras de Santomé (1995), que reproduz a marginalização e nega a existência de outras culturas distintas da hegemônica. É importante que não haja supervalorização da dimensão biológica, uma vez que o biologismo impossibilita a compreensão do racialismo forjado como força político-ideológica negadora das lutas dos grupos sociais que defendem a cultura afrodescendente.

O desafio é ampliar o "campo de possibilidades" epistemológicas da escola de Ensino Fundamental, a fim de assegurar uma abertura possível para uma outra compreensão do que é ser humano, que valorize tanto a dimensão biológica como a étnica e seus aspectos relacionais (religioso, histórico, social, político, econômico, mítico). A busca de uma fundamentação epistemológica de natureza crítica deve ser encarada como uma ação necessária em nosso cotidiano escolar, construída na diversidade de grupos étnicos distintos. Dessa forma, outra questão se coloca: Que escola e que formação pedagógica serão capazes de considerar a diversidade humana em suas interpretações? 
A partir dessas perguntas, assumimos o seguinte percurso argumentativo, apresentado em forma de capítulos. No primeiro momento, aprofundamos o conceito de infância articulado com o de criança, traçando um pouco da história do pensamento construído acerca dessa dimensão de humanidade, avançando da concepção natural de infância à concepção histórica e as suas relações com o contexto brasileiro. A partir daí, aprofundamos o conceito de infância afrodescendente, explicitando os elementos culturais que a constituem. Finalmente, neste primeiro momento, discutimos " $\mathrm{O}$ lugar" da criança afrodescendente enquanto sujeito de direitos, principalmente tomando os artigos do Estatuto da Criança e do Adolescente, já citados anteriormente, bem como a análise de Maria Luiza Marcílio (1998) acerca da temática.

No segundo momento argumentativo, consideramos a articulação entre afrodescendência e Ciência da Educação. O foco da discussão é a produção de conhecimento da criança de tradição africana e a epistemologia do educador. Como se dá essa relação na escola do Ensino Fundamental contemporâneo, visto que a mesma ainda perpetua uma racionalidade moderno-colonialista para pensar o sujeito? Neste sentido, discutimos os caminhos cientificamente trilhados pelo educador e as relações com o conhecimento produzido pelo educando (criança afrodescendente).

No terceiro e último momento, construímos o pensamento sobre a história e a cientificidade do Ensino Fundamental, fazendo uma crítica à Escola como cenário de representações e, em paralelo a essa discussão, definimos a Escola como espaço de presença e de solidariedade. Esta discussão se faz importante, a fim de apresentar maiores esclarecimentos sobre a forma como, historicamente, a Escola Fundamental vem se organizando para ampliar a compreensão acerca das justificativas da exclusão da cultura afrodescendente no nível escolar. Em contrapartida, no mesmo capítulo, analisamos a possibilidade de a Escola Fundamental 
assumir uma prática mais solidária e aberta à diversidade, em que a criança afrodescendente possa ser, de fato, um ser de presença, valorizada em sua experiência.

As discussões sugerem uma re-significação da Ciência da Educação que considere uma epistemologia crítica inspirada nos princípios da tradição afrodescendente, principalmente, e "abrace" a infância desse grupo social em sua cultura.

Consideramos importante, ainda, sistematizar um pequeno glossário, a fim de possibilitar maiores esclarecimentos sobre algumas palavras e conceitos apresentados nos capítulos.

Enfim, a presente obra sugere um horizonte compreensivo aberto e ao mesmo tempo consciente de sua demarcação momentânea, que articule Ciência da Educação, Infância e Afrodescendência. Isso implica a necessidade de dialogias com obras que complementam, de certa forma, as reflexões postas neste texto, principalmente no sentido da religiosidade e narrativa mítica de tradição africana ${ }^{4}$, citadas nas referências, com destaque para Lima (2003), Luz (2000), Prandi (2001), Rodrigué (2001), Siqueira (1998) e Verger (1981). Estas obras, decerto, contribuem sobremaneira com as discussões postas nesta obra, já que o objetivo principal não é construir exaustiva discussão, principalmente sobre religiosidade, tarefa, aliás, já realizada pelos autores citados. O que mobiliza esta obra e a torna original é a discussão, de natureza crítica, de alguns fundamentos da tradição afrodescendente na Bahia, visando colaborar para um repensar dos modos de produção da ciência da educação no ensino fundamental. 



\section{capitulo (9 \\ O QUE É ISTO - A INFÂNCLA?}

A procura ciente pode transformar-se em "investigação" se o que se questiona for determinado de maneira libertadora.

Heidegger (1996, p. 19)

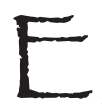

studar a infância é o desafio posto na contemporaneidade, pois, decerto, ainda não é bem compreendida. Em pleno século XXI, ainda se faz presente o alerta de Rousseau (1999, p. 4) em Emílio ou Da Educação, no século XVIII: "Não se conhece a infância; no caminho das falsas idéias que se têm, quanto mais se anda, mais se fica perdido [...]"

Considerando que a busca de sentido sobre a infância é atitude necessária, façamo-nos então a seguinte pergunta: O que é isto - A infância? De natureza filosófica, esta pergunta é formulada no sentido de considerarmos a atitude de nos lançarmos para fora, afastarmo-nos num primeiro momento e reconhecermos que é um conceito ainda incompreensível, em certa medida enigmático, para logo voltarmos e penetrarmos em seu sentido ou em suas várias possibilidades de sentido.

A pergunta "O que é isto - A infância?" nos remete à necessidade de conceituação, ou seja, Isto é... no sentido de investigarmos o modo, a essência ou o sentido de ser dos entes, sejam eles naturais, físicos, artificiais, humanos. Investigar o sentido 
dos entes em sua dimensão humana envolve, para Heidegger (2002), tudo que falamos, tudo o que entendemos, como nos comportamos. Ente é tudo o que e como nós mesmos somos. Já Chauí (1997) considera que entes são as coisas reais materiais ou naturais (fruta, árvore, sol, pedras...), as coisas materiais artificiais (mesa, casa, roupas...), os entes ideais (idéias concebidas pelo pensamento idealidades). Entes podem ser ainda valores (beleza, feiúra, bom, mal, verdadeiro, falso...) e entes metafísicos (divindade ou absoluto, infinito, nada, morte, imortalidade, identidade, alteridade...). Investigar, então, o ser do ente infância, perguntando o que é isto, não no sentido de fechar o sentido num isto é enquanto verdade absoluta, definida, acabada, mas enquanto "possibilidade" de ser é o desafio que nos impomos.

A questão "O que é isto - A infância?" nos coloca frente a um horizonte de sentidos possíveis construídos pela potência histórica que marca o pensamento elaborado até então. Compreender o que a infância é, abre a necessidade de esclarecimento sobre o que um conceito é. Segundo Agea (2002), o ato de conceituar tem geralmente uma potencialidade redutora do objeto a ser conceituado e pode despertar discordâncias. Em sua perspectiva, todo conceito tende a não permitir boa visualização do entorno. No entanto, se considerarmos o que sugerem Deleuse e Guattari (1992, p.13), abriremos outra vertente de entendimento:

Todo conceito é uma multiplicidade, apesar de não pretender possuir todos os componentes [...] Todo conceito é um contorno irregular, é articulação, corte, superposição [...] Todo conceito totaliza seus componentes, mas é um todo fragmentário [...] Apesar de datados, assinados e batizados, os conceitos têm sua maneira de não morrer, e, todavia são submetidos a exigências de renovação, de substituição, de mutação.

Nesse sentido, o conceito de infância, em sua complexidade, assume colorações distintas, porque é historicamente datado, assinado e batizado segundo concepções e visões de mundo. 
Tomando essa perspectiva, cabe um esclarecimento inicial sobre a diferença fundamental entre os conceitos de infância e criança. Segundo Pilotti (1995), do Instituto Interamericano Del Niño, o sentido dado à palavra criança remete à dinâmica do desenvolvimento individual, numa dimensão mais psicológica. Já o sentido atribuído à palavra infância localiza-se na dinâmica social, histórica e cultural em que esta criança se encontre efetivamente. Por isso, criança e infância são palavras complementares e interdependentes. No contexto brasileiro, criança é legalmente definida e apresentada pelo Estatuto da Criança e do Adolescente (ECA) como a pessoa que possui idade entre 0 e 12 anos incompletos (DARLAN, 1998). Portanto, nesta obra, faremos referência a ambos os termos, dependendo do contexto argumentativo.

\subsection{CONCEPÇÃO NATURAL DE INFÂNCIA}

Voltemos então à nossa busca de sentido: "O que é isto A infância?" Esta pergunta não se revelou como "fonte de inquietações" dos homens antigos e medievais (e em alguns discursos modernos), porque não havia lugar para a infância em seus mundos. Significa dizer que se não há lugar para a pergunta intencionalmente colocada, é porque não há visibilidade política, social e histórica para essa situação de humanidade. A própria etimologia da palavra confirma essa idéia: Enfante, derivado do latim infans, é criança e significa ser destituído de fala, sem lugar no discurso (FREITAS, 2001). Foi a partir desse entendimento que alguns outros conceitos foram construídos no decorrer da história. O percebido é que, para se chegar a uma explicação de infância, sempre se tomava o adulto como referência. $\mathrm{O}$ adulto era o centro, enquanto as crianças eram sua extensão.

Em Aristóteles, por exemplo, a infância é vista a partir da visão "machista". Ela deve incorporar as características do pai, porque ele é ativo, soberano e, por isso, bem diferente da mulher. $\mathrm{Na}$ 
mulher falta algo. Ela é um homem incompleto, é passiva e receptora na reprodução. As características femininas são negativas na construção da infância. Se a infância é construção a partir de características já dadas pelo pai, significa dizer que ela não tem direito à manifestação própria, não participa do discurso enquanto presença efetiva. Aristóteles responde à nossa pergunta da seguinte forma: infância é o prolongamento individual e natural do pai.

Já Platão apresenta uma visão mais "positiva" de infância, porque também a sua visão sobre a mulher era positiva. A infância, igualmente, assume as características femininas. Em seu diálogo O Banquete, é uma mulher (Diotima) que abre a Sócrates as portas da filosofia. Platão foi o primeiro filósofo a defender a criação dos jardins de infância e semi-internatos públicos. Para ele, a Educação Infantil era muito importante para ser de responsabilidade individual ou privada. Os cuidados com a infância deveriam ser de responsabilidade do Estado. Nesse sentido, para Platão, infância é prolongamento natural do pai e da mãe e de responsabilidade do Estado.

Santo Agostinho, assim como a etimologia da palavra sugere, via a infância também como destituída de linguagem, de logos. Era desprovida da razão, que se constituía como a condição divina dos adultos, bem como estava imersa no pecado, na corrupção e na mentira, características que a afastavam do divino. A criança não possuía a divindade natural necessária ao ser humano. Neste sentido, sua condição de humanidade foi negada. A infância era uma etapa de vida a ser vencida o quanto antes. Santo Agostinho, segundo a teologia cristã, responde a nossa pergunta da seguinte forma: a infância é naturalmente pecadora, inocente e destituída de logos.

De maneira aproximada pensava Descartes ${ }^{5}$. Ghiraldelli Jr (2003) afirma que Descartes, ao discutir as dificuldades no uso da razão e os conseqüentes erros daí derivados, aponta negativamente para 
a infancia, já que nesta fase a imaginação, os sentidos, a emoção e as sensações sobre a razão são presenças marcantes e dimensões naturais da criança. Sua fala reafirma essa idéia:

[...] os sentidos e imaginação produzem pensamentos não confiáveis, dos quais se pode duvidar, que são, portanto, descartados metodologicamente; em vez deles, são acolhidos pelo juízo aqueles pensamentos claros, porque iluminados pela luz da razão, totalmente expostos aos olhos atentos da mente pura, isto é, desvinculada dos sentidos. (GHIRALDELLI JR, 2003, p.19).

Por isso, sob o seu olhar, a infância é vista como maléfica para a formação do homem racional. Essa etapa, assim como pensava Santo Agostinho, deveria ser vencida com urgência. Para Descartes, a infância é naturalmente irracional e uma etapa dificultadora para a formação do homem de mente pura, iluminada pela razão.

Com Rousseau, há uma desconstrução dessas visões de infância. A infância é amiga da filosofia, já que as suas principais características são a verdade e o bem; a criança é moralmente correta. O erro, a mentira e a corrupção são características dos adultos porque estes não apresentam um coração puro e sincero como é próprio da infância. Para Rousseau (1999), só a razão ensina a conhecer o bem e o mal. Por isso, antes da idade da razãa só conhecemos o bem. Segundo ele:

Só a razão nos ensina a conhecer o bem e o mal. A consciência que nos faz amar a um e odiar ao outro, embora independentemente da razão, não se pode, pois, desenvolver-se sem ela. Antes da idade da razão, fazemos o bem e o mal sem sabêlo, e não há moralidade em nossas ações [...] (ROUSSEAU, 1999, p.53).

Essa bondade caracterizadora da infância, em Rousseau (1999), é natural. Mas Ghiraldelli Jr. (2003) avalia que Nabokov se contrapõe a Rousseau quando afirma que nada de inocente e bom há na infância; ao contrário, pode haver, também naturalmente, algo de 
bem perverso. Então, para Rousseau (1999), a infância é naturalmente verdadeira e boa, enquanto para Nabokov (1994) ela é naturalmente má. O esquema apresentado a seguir expõe uma síntese da concepção natural de infância na perspectiva desses autores.

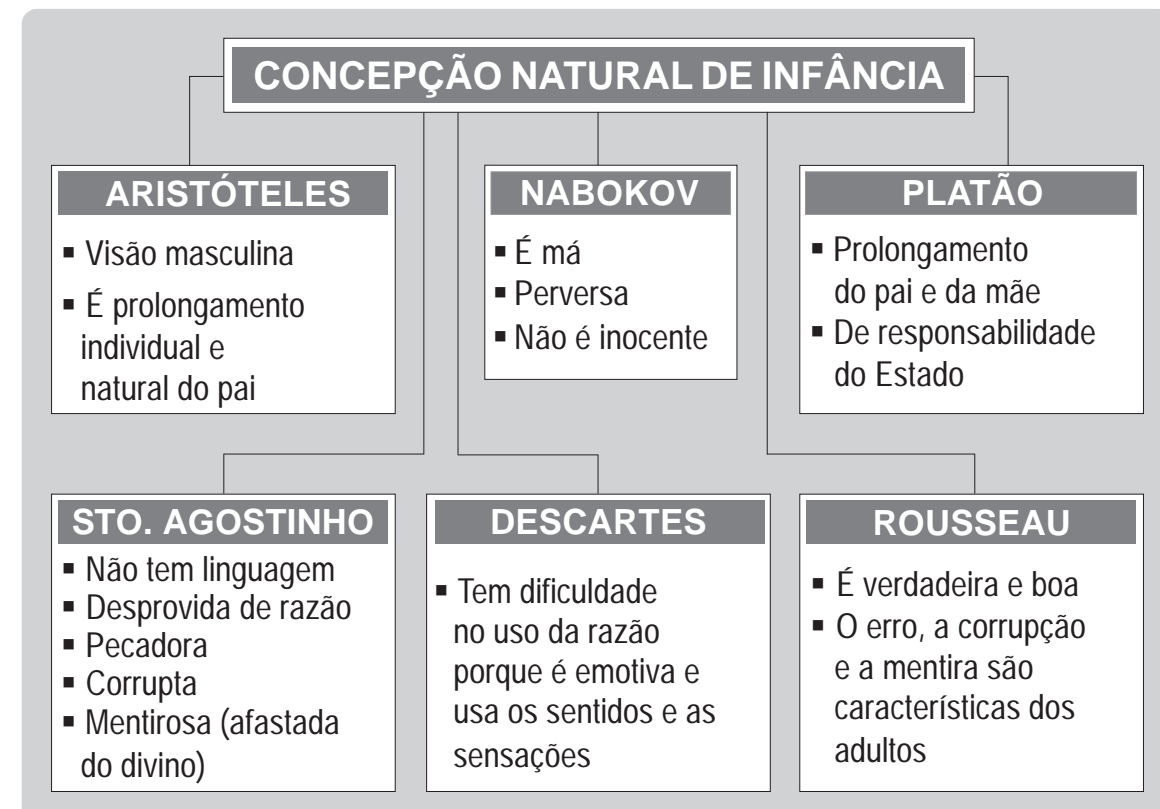

\author{
ESQUEMA 1 \\ Concepção NAtural de Infância
}

Nessa rápida incursão no pensamento construído sobre a infância, notamos que os conceitos, na sua diversidade reflexiva, respondem à pergunta "O que é isto - A infância?" de maneira aproximada: a infância é algo natural; ou naturalmente boa, má, irracional, pecadora, inocente, ou porque é naturalmente o prolongamento do pai e da mãe. 
A partir do pensamento estruturado por Hegel, entretanto, quando o mundo passa a não ser mais visto como algo puramente natural, a infância também será vista como historicamente construída.

\subsection{CONCEPÇÃO HISTÓRICA DE INFÂNCIA E O CONTEXTO BRASILEIRO}

No século XVIII, a infância deveria ser resguardada porque a sua mão-de-obra era útil. Sua preservação estava relacionada ao fato de se tornarem futuros adultos trabalhadores. Esta visão era favorável ao momento histórico moderno em sua configuração industrial. Neste sentido, o conceito de infância já compreende uma dimensão histórica e social, mas se limita a ser sujeito que trabalha.

No início do século XIX, se fortalece a idéia de que a infância é construção da Sociedade, da Cultura e da Escola. Na década de 60 do século XX, Ariès (1981) reafirma essa compreensão. A partir de Ariès, a infância é pensada enquanto construção social, mas essa construção é montada a partir das novas formas de falar, pensar e sentir dos adultos em relação ao que fazer com ela. A exposição infantil às situações reveladoras dos conflitos e problemas de natureza social, típicos da época Moderna, faz com que os adultos, em certa medida, iniciem um movimento de descoberta, valorização e proteção das crianças. Freitas (2001, p. 93), esclarece:

Até o advento da modernidade, da industrialização, a criança não se constituía como uma categoria importante para o mundo do adulto que nem sequer percebia a sua existência. Quando o trabalho deixou de ser no próprio lar, as famílias passaram a se deslocar, fazendo da existência das crianças um problema a ser resolvido. Com o advento da indústria, as mulheres e crianças foram também utilizadas.

Essa idéia organiza o seguinte conceito: a infância é um problema para o processo industrial. Notamos que a visibilidade social da criança se inicia a partir de interesses que dizem respeito à vida 
dos adultos, numa relação com a satisfação de suas necessidades. Essa visibilidade social, entretanto, não diz respeito à própria criança em sua existência.

Um outro conceito construído na modernidade, sobre a infância, diz respeito também ao processo de industrialização, quando sugere que a criança é um sujeito que consome. $\mathrm{O}$ aumento assustador da produção industrial de fraldas descartáveis e de todo um arsenal de produtos para bebês põe a criança sob o holofote industrial. A criança é vista como sujeito econômico e, portanto, é útil para a indústria.

$\mathrm{Na}$ época moderna brasileira, além das idéias sobre a infância citadas acima, articulam-se outras, sugeridas pelo processo de colonização. Para compreendê-las, é importante considerar o contexto que impulsionou esse processo.

Final do século XV e início do XVI. A bistória comesa ${ }^{6} \mathrm{com}$ a descoberta do Novo Mundo. A curiosidade Renascentista volta-se para as Américas, devido ao deslocamento das atenções, até então, sobre a Ásia e a África. Esse olhar curioso é lançado principalmente sobre a fauna e a flora, por entendê-las como exóticas. As Américas são definidas como paraíso, precisamente por causa da natureza. A outra dimensão do olhar curioso se deu sobre as gentes estranhas em costume e civilização. O olhar de estranheza impulsiona discussão sobre a Humanidade existente nas Américas. A idéia de humanidade que compõe as gentes das Américas se funda no canibalismo, na nudez e na poligamia. Esses componentes são o eixo que fortalecerá a dúvida sobre a condição de humanidade dos indígenas. Vejamos o comentário de Schwarcz (2000, p.14-15):

No tocante à humanidade [...] o canibalismo, a poligamia e a nudez desses homens escandalizava as elites pensantes européias que tinham dúvidas sobre a humanidade desses indígenas [...] Esse impasse toma uma forma mais delineada a partir do famoso embate que opôs Bartolomeu de Las Casas, ao jurista Sepúlveda, 
que partia de uma dúvida primordial: "seriam essas novas gentes homens ou bestas". Nesse caso, enquanto Las Casas defendia a inferioridade dos indígenas, assegurava, contudo, sua inquebrantável humanidade; Sepúlveda reconhecia encontrar nesses "primitivos" uma outra humanidade [...] Um bom termômetro dessa inquietação é, sem dúvida, o texto de Monteigne chamado "Os canibais" [...] o famoso filósofo francês [...] desabafa: "Tudo isso é em verdade interessante, mas, que diabo, essa gente não usa calças!".

A natureza da discussão revela as relações estabelecidas em terra firme. O etnocentrismo presente nos discursos e nas ações é o caminho pensado para o debate sobre a humanidade dos indígenas. Santomé (1995) considera que as práticas de natureza etnocêntricas consistem em julgar como certo ou errado, bonito ou feio, normal ou anormal comportamentos e visões de mundo de outros povos, tomando como referência os seus próprios padrões. Daí pode ser gerada uma desqualificação ou a própria negação da humanidade do outro. A crença moderna em progresso humano como único, linear e determinado, diz respeito também às questões raciais/ étnicas. Para o Ocidente branco, o único modelo (linear, determinado e inquebrantável) de humanidade é o experimentado por ele próprio.

Nesse sentido, a construção da idéia dos indígenas como seres incivilizados, sem humanidade ou de humanidade "distorcida" funda a compreensão da época. O "indiozinho" precisa aprender a ser civilizado (catequizado pelos jesuítas) na "casa dos muchachos". "A casa dos muchachos era o lugar onde os indiozinhos eram criados e catequizados pelos jesuítas, junto com órfãos portugueses, para que tivessem um modelo para aprender os modos considerados civilizados com outros da mesma faixa etária." (FREITAS, 2001, p.96). É bem verdade que, para os jesuítas, a tarefa de civilizar os índios não foi, em geral, bem sucedida, já que os indiożinhos tinham sua cultura enraizada e, por isso, difícil de abandonar completamente (FREITAS, 2001). Ainda assim, o conceito de infância suge- 
rido, a partir desse contexto, resume-se em: A infância indígena é destituída de humanidade, incivilizada, em oposição à branca, aquela que possibilitaria o modelo de civilidade. A infância branca é conceituada como a civilizada, portadora de humanidade, exemplo de beleza e nobreza.

No período colonial brasileiro, faz-se presente também outra idéia de infância, agora para os filhos dos escravos. Além de destituída de bumanidade, incivilizada, era também um problema, já que teria que ser alimentada e formada em um ofício, gerando prejuízos para o sistema escravista-latifundiário. Os brancos-europeus interessavam-se pelos escravos adultos, por gerarem lucro imediato, a partir da mãode-obra já pronta para a exploração pelo trabalho.

O sistema escravista-latifundiário brasileiro apresentou, como um dos principais fundamentos, a negação da liberdade dos negros trazidos do Continente Africano. Isto porque, a liberdade como direito que deve ser garantido a todos só "pode" ser negada aos não humanos, segundo discussão implícita nos discursos jurídicos. Sendo assim, o negro foi pensado como não humano e, portanto, não tinha direito à liberdade. Essa agressão à condição de humanidade do negro fez surgir, em nossa ótica, os fenômenos que mais tarde fundamentaram a cultura da maior parte dos brasileiros até a atualidade (negros, índios e mestiços): a invisibilidade e a anonimidade. Partindo desse pressuposto, parece claro que a definição da infância negra se reduz a sujeito que não possui humanidade e liberdade, incivilizada, inútil para o sistema latifundiário, anônima e invisível socialmente.

Além dos conceitos de infância forjados para os índios, brancos e negros, há a presença da infância mestiça, aquela se dá a partir do hibridismo que surge das relações inter-étnicas. As crianças mestiças eram vistas como o resultado da degeneração humana, visto que o resultado da mistura se dava a partir do apagamento das melhores qualidades dos brancos, dos negros e dos índios. Essa idéia, 
construída pelos europeus que aqui estiveram, mais precisamente no século XIX, é contada por Schwarcz (2000, p.23):

Aos olhos de fora, o Brasil há muito tempo era visto como uma espécie de laboratório racial, como um local onde a mistura de raças era mais interessante de ser observada do que a própria natureza. Agassiz, por exemplo, suíço que esteve no Brasil em 1865, assim concluía seu relato: "que qualquer um que duvide dos males da mistura de raças, e inclua por mal-entendida filantropia, a botar abaixo todas as barreiras que a separam, venha ao Brasil. Não poderá negar a deterioração decorrente de amálgama das raças mais geral aqui do que em qualquer outro país do mundo, e que vai apagando rapidamente as melhores qualidades do branco, do negro e do índio, deixando um tipo indefinido, híbrido, deficiente em energia e mental" [...] Gobineau, que permaneceu no Brasil durante quinze meses, como enviado francês, queixava-se: "Trata-se de uma população totalmente mulata, viciada no sangue e no espírito e assustadoramente feia" $[\ldots]$

Notamos que a mestiçagem é violentamente pensada de forma negativa pelos brancos-europeus do século XIX. Sua presença, nesse contexto, representava o atraso e a inviabilidade de se construir uma nação. Tomando essa defesa, tem início, na década de 20 do século XX, a política do embranquecimento, que vai adotar como principal via a imigração branco-européia. O pensamento produzido na Faculdade de Direito de Recife, que tinha como grandes modelos de análise as escolas darwinista social e evolucionista, defendia a imigração como única possibilidade de construção de futuro da nação, já que o embranquecimento da população seria o eixo fundamental, capaz de melhor qualificar as produções locais (SCHWARCZ, 2000). Enquanto Recife produzia conhecimento, a cidade de São Paulo iniciava a operacionalização da política do embranquecimento. Alemães, italianos, austríacos, holandeses, ingleses e espanhóis seriam incorporados à população, a partir das necessidades trabalbistas da época. O desejo era um futuro branco e sem conflitos. 
Nessa dinâmica, a idéia de infância mestiça foi construída como resultado de degeneração racial, deficiente em energia e construção mental, destituída de qualidades culturais, muito feia e sujeito inviabilizador do futuro e progresso da nação. Mas os contextos são dinâmicos e possibilitam outras vias de pensamento capazes de impulsionar e/ou revelar outras construções de infância.

Observe a síntese apresentada na figura a seguir:

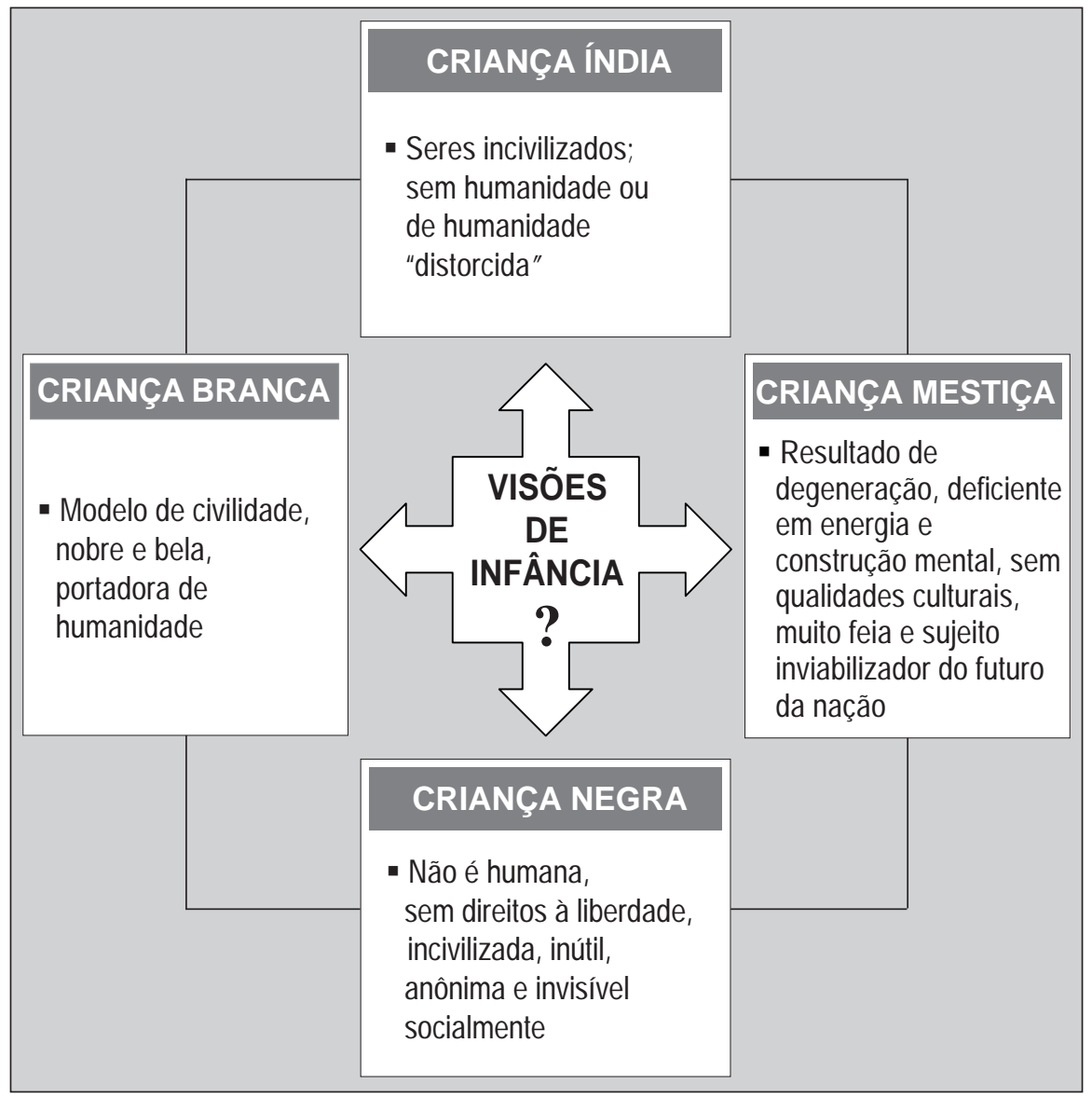




\subsubsection{A infância de origem afrodescendente}

Como reflete Galeffi (2002, p.69): “[...] em nenhum momento penso em soluções fáceis, porque reconheço o quanto seja preciso fazer para mudar os rumos destinais de um povo modernamente constituído e projetado em suas possibilidades instrumentais." Ainda assim, arriscamo-nos a pensar em outras perspectivas. Para isso, é tarefa necessária pôr em debate o processo de construção da afrodescendência na Bahia, a dinâmica de conservação e reelaboração dos valores culturais de matriz africana e o enfrentamento estratégico e criativo durante o processo de escravidão empreendido pelos portugueses no período moderno brasileiro (desde as suas origens nos séculos XVI-XVII até sua culminância no século XIX).

Nos parágrafos anteriores, discutimos os conceitos de infância negra, branca, índia e mestiça possibilitados por esse contexto, bem como revelamos um dos projetos políticos pensados para o Brasil: a política do embranquecimento. Esta política visava negar a existência e excluir os negros, índios e mestiços da nação brasileira. Em nossa perspectiva, foi essa política que produziu o convívio desses grupos étnicos com um tipo de negação e silenciamento de humanidade impostos e, ao mesmo tempo, com a tentativa de assegurar tradições culturais violentadas nesse percurso histórico. $\mathrm{O}$ conflito pessoal e coletivo foi experimentado por esses grupos, principalmente por índios e negros, no sentido de serem obrigados a negar e silenciar sua humanidade e, ao mesmo tempo, desejar manter suas tradições culturais.

Mesmo com o processo de descolonização marcado pela independência política de Portugal, dos conflitos e insurreições ocorridos a partir da segunda metade do século XIX, parece-nos claro que o Brasil, ainda hoje, vive a sua existência fundada na antiga ordem moderno/colonial/escravista, em conflito com os novos 
valores da sociedade de grupos emergentes. Isto se evidencia no cotidiano de profunda desigualdade, desrespeito e discriminação social, política e cultural, na tentativa dessas minorias ${ }^{7}$ étnicas de assumirem o seu lugar na história, não a partir do apagamento das demais, mas a partir do jogo tensivo possibilitado pela dimensão de alteridade que as constitui.

Nessa perspectiva, para pensar a infância de origem afrodescendente na contemporaneidade, faz-se necessário discutir historicamente a sua origem, a sua ancestralidade. Segundo crianças da escola São Roque do Lobato/Salvador-Bahia, podemos começar a defini-la da seguinte forma:

Afrodescendência é quando uma pessoa é depend... é parente de outra que morava na África. (Alexnaldo).

Afrodescendentes são pessoas negras e que podem ser filhos de pessoas que vieram da África e que veio pro Brasil muito tempo atrás. (Marcelo).

Esse pode ser o ponto de partida, mas conceituar a infância (ou criança) afrodescendente numa dimensão moderna de identidade parece um risco, já que estamos nos referindo a um grupo étnico constituído a partir de uma pluralidade cultural e biológico/racial que, por si, já desloca a fixidez identitária para o plano da alteridade. Ou seja, a identidade da criança afrodescendente se dá a partir de múltiplos elementos. Ela é multifacetada, complexa, no sentido de que possui elementos diversos oriundos de grupos étnicos africanos e racionalidades distintas que se articulam e formam um todo. Os africanos que chegaram à Bahia foram solidários entre si e “[...] terminaram por constituir uma cultura africana original [...] a partir das várias matrizes culturais de que eram portadores." (ARAÚJO et al., 1999, p.10). Para melhor compreendermos essa construção de identidade e conceituarmos a afrodescendência, faremos uma rápida incursão no tempo (história da chegada dos negros escravizados) e no espaço (do território africano ao território baiano). 
As análises históricas realizadas acerca da chegada dos vários grupos étnicos africanos à Bahia são imprecisas em alguns pontos, mas nos dão significativa idéia da diversidade étnica africana que vai estruturar a cultura afrodescendente em nosso território.

Três milhões e meio de escravos africanos (AGIER, 2000) entraram no Brasil entre a metade do século XVI e metade do século XIX, trazidos pela coroa portuguesa, a fim de possibilitar o desenvolvimento econômico. Esse povoamento foi feito essencialmente pelo porto de Salvador. Os escravos forneciam mão-de-obra para as plantações e usinas de açúcar ao redor da Bahia e também eram utilizados como empregados domésticos e prestadores de outros serviços no próprio porto.

Segundo Agier (2000), as populações africanas importadas pela rede do tráfico transatlântico de escravos foram inicialmente sudanesas (vieram das regiões setentrionais da África do Oeste), depois banto (ciclo do Congo e de Angola, a partir do século XVII), depois sudanesas novamente (a partir do século XVIII até metade do século XIX, vindo especialmente da área cultural FonYoruba, embarcadas na Costa de Mina e na Costa dos Escravos no Golfo de Benin).

$\mathrm{Na}$ análise de Reis e Gomes (1996), o tráfico de escravos africanos nas Américas envolveu grande número de homens e mulheres que foram violentamente arrancados de suas terras: cerca de 15 milhões. Na diáspora brasileira, essa "trágica aventura" foi imensa. A estimativa é de que aqui chegaram, em média, 40\% dos escravos africanos. Segundo Funari (1996, p.29): “Em 1570, já havia mais de cinqüenta engenhos na colônia e, em 1584, 15 mil escravos por aqui labutavam nas fazendas." Em meio a esse processo,

A capitania da Bahia foi por muito tempo importante terminal do tráfico de escravos, mas as mudanças na economia atlântica, especialmente com a revolução haitiana de 1792, criaram novas condições para a expansão da escravidão em terras baianas. No início do século XIX, cerca de 8 mil a 10 mil africanos chegavam 
anualmente ao porto de Salvador. Entre dois terços e três quartos desses africanos vinham do Golfo de Benim ou do que os portugueses chamavam de Costa da Mina. Em 1806, por exemplo, 8037 minas desembarcaram na Bahia, comparados com 2588 escravos de Angola e Benguela [...] Na primeira década do século XIX, a capitania como um todo tinha uma população de mais de 400 mil pessoas, das quais um terço era de escravos. Salvador tinha uma população de mais de 400 mil pessoas, cerca da metade formada por negros, $22 \%$ por pardos e apenas cerca de $25 \%$ por brancos. O que distinguia a população escrava de Salvador da do resto da capitania (e também daquela da maior parte do Brasil), e que sempre provocava comentários de viajantes estrangeiros, era a origem africana da maioria dos escravos. Na Bahia desse período os africanos provavelmente representavam $60 \%$ da população escrava. (SCHWARTZ, S., 1996, p. 374-376).

Para Cortes (2002), as primeiras notícias da chegada de africanos à Bahia datam de 1550. Os negros da Guiné, que aqui chegaram, pertenciam a diversas nações de uma abrangente região que vai da chamada Senegâmbia ao reino do Congo. No início de 1600, Angola foi o primeiro fornecedor de escravos, liderando a África Centro-Meridional por mais de três séculos. Até meados do século XVIII, predominaram africanos das nações de língua banto, aqui nomeados de formas diversas: Congos, Angolas, Cabindas e Benguelas. Ainda segundo a autora, até meados do século XVIII, a grande importação de escravos da Costa da Mina dava a impressão de que a cultura afrobaiana limitava-se às contribuições dos escravos trazidos desse local e, posteriormente, da baía de Benin (conhecidos como Minas, Jejes, Nagôs, Tapas, Hauças, Calabar, Galinhas e outros). Essas denominações, forjadas no circuito do tráfico negreiro, não correspondiam às formas de auto-identificação que os grupos utilizavam na África. Como exemplo, Cortes (2002, p.3) cita os Jeje e Nagô:

Jeje era um imenso "guarda-chuva" que abrigava os Fon, do Daomé; os Gun, de Porto Novo; os Xweda, de Ajuda; os Mina, de Anécho; os Mahi, de Savalu. O mesmo acontecia com Nagô, que se aplicava tanto à gente de Oyo, quanto de Ketu e de Ifé, aos Ijexá, aos Egba, aos Ijebu, etc. Quem os chamava de Nagô 
eram os "outros", e foi este o nome que aqui se fixou [...] $\mathrm{Na}$ Bahia, quando os próprios Nagôs eram chamados a declinar suas origens, valiam-se de expressões como Nagô-Ba (Egba), Nagô-Jebu (Ijebu), Nagô-Jexá (Ijexá) e outras. O interessante nesse processo era o fato de aceitarem a pretensa unidade expressa pelo termo Nagô, enquanto mantinham para "uso doméstico", se assim podemos dizer, os nomes que consideravam como suas verdadeiras marcas de origem.

Percebemos que a composição da identidade do afrodescendente na Bahia, tanto no sentido territorial quanto étnico, foi mediatizada pela diversidade de grupos africanos distintos, vindos também de regiões diversas da África; conseqüentemente, a organização cultural originária do afrodescendente na Bahia também se organizou tendo como eixo a diversidade étnica e cultural desses vários grupos.

Na citação de Cortes (2002) fica evidente sua inquietação frente à aceitação dos grupos étnicos citados em relação à denominação que confere unidade. Isto porque, os africanos reelaboraram seus critérios de auto-identificação e incorporaram novos elementos culturais aos originais, salvaguardados pela memória. Segundo Oliveira (2003), os valores e os princípios das culturas dos grupos étnicos africanos que chegaram ao Brasil e constituíram a identidade do povo negro (principalmente na Bahia) foram re-construídos, nunca abandonados, preservando, com isso, sua matriz africana. Quanto a esta recriação ou redefinição identitária, Oliveira (2003, p.83) esclarece:

[... esta redefinição identitária não se faz a partir do princípio de identidade, da afirmação do mesmo. É a partir da diferença que se constroem os referenciais identitários. A identidade se constrói com relação à alteridade. Com aquilo que não sou eu. É diante da diferença do outro que a minha identidade aparece.

Cortes (2002) afirma que identidade é o conceito fundante de toda etnia. A identidade é compreendida como a própria linguagem em que os grupos étnicos categorizam-se a si e aos outros com fins 
de interação em situações de contato interétnico. É um sistema de classificação e de relações sociais que une os indivíduos segundo a sua origem e formação.

Sendo assim, os africanos que aqui chegaram, refizeram seus referenciais identitários, buscando manter a matriz africana comum, através dos valores e princípios presentificados principalmente nas línguas intercomunicantes e nos sistemas míticos comuns. Para Lima (2003), foi inevitável a aceitação de mudanças em sua estrutura identitária, no entanto o "povo de santo" procurou manter firme e sofridamente a fidelidade às suas crenças ancestrais, mitos e valores africanos.

Aqui na Bahia, das antigas nações africanas que se fixaram nos séculos XVIII e XIX, Lima (2003) ressalta a dos iorubas-nagôs (jeje-nagô), como a que melhor conservou sua matriz africana original. Apesar do sistema mítico Jeje-Nagô, segundo Cortes (2002), ter dado origem ao culto afrobaiano de maior expressão ainda hoje na Bahia, é a identidade grupal, no entanto, a base de formação dos africanos e de seus descendentes em nosso território.

Essa identidade grupal foi claramente organizada nos terreiros de Candomblé. Esses espaços aqui organizados representavam uma possibilidade de manter os laços que uniam os africanos a seus parentes e ao território, visto que, com o processo de escravidão, os laços de familia foram rompidos. Isso resultou na forma criativa de reconstrução de vinculos parentais, agora não mais pautados no sangue e no nome de família, mas na capacidade de novos e complexos lacos, tendo o culto aos ancestrais como principal meio de reconciliação. Esse ato reconciliador foi a principal forma encontrada pelos negros africanos e seus descendentes na Bahia de validar a profunda relação desses sujeitos com a experiência vivida na África. O culto aos ancestrais era uma das práticas sociais mais importantes para os grupos étnicos africanos e caminho efetivo de reconciliação com a experiência e com os seus ancestrais. Na perspectiva de Oliveira (2003, p.155), o Candomblé é: 
Síntese de várias expressões religiosas africanas, nele reuniramse várias cosmovisões de etnias diferenciadas e acabou por se estruturar uma cosmovisão de matriz africana dos principais aspectos civilizatórios que existia na África tradicional. Esses elementos atravessaram o Atlântico e, apesar de estarem em novas terras e sob novas condições, preservaram os elementos estruturantes daquelas sociedades, mantendo sua tradição e afirmando sua identidade.

Os africanos e seus descendentes na Bahia se fizeram unidos aos seus parentes, ao território africano e à sua experiência, através dos laços de solidariedade e dos cultos (que envolve musicalidade, dança, contato com a natureza e tradição oral) praticados nos terreiros de Candomblé. Essa instituição religiosa permitiu a continuidade do legado dos valores africanos. Para Luz (2000, p. 32), a religião, desde a África, “[...] ocupa um lugar de irradiação de valores que sedimentam a coesão e a harmonia social, abrangendo, portanto, relações do homem com o mundo natural." As religiões africanas, portanto, permitiam ampla organização social. Hoje, na Bahia, segundo dados divulgados pelo Instituto Brasileiro de Geografia e Estatística (IBGE, 2003), há, em média, 21.733 pessoas que se declararam praticantes da religião, incluindo-se aí os praticantes de umbanda. Na Bahia, há cerca de 5.600 terreiros de Candomblé, dentre Casas de Umbanda e Centros de Caboclos (PAI ARI, 2004). Como prática religiosa, o Candomblé só foi liberado oficialmente, na Bahia, em 15 de janeiro de 1976, pelo governo de Roberto Santos (MACHADO, 1999).

$\mathrm{Na}$ Bahia, como já afirmado anteriormente, os jeje-nagô, com sua expressão cultural, seus princípios e valores, são a influência mais marcante nos terreiros de Candomblé. Com sistema mítico e línguas aparentadas, eles se reúnem nessas comunidades religiosas para cultuar divindades, sob a liderança de um sacerdote ou sacerdotiza de Ketu, cidade cujo orixá é Oxossi. Neste mesmo espaço, segundo Cortes (2002), cultua-se Xangô, orixá da gente de Oyo; Iemanjá, da gente de Egbá; Oxum, da gente de Ijexá; Ogum, da gente dos Ekiti; 
Oxalufan, dos Ifan; Oxalá, da gente de Ifé. Ao lado desses orixás nagôs são também cultuadas divindades de outras nações.

O culto a essas várias divindades representa não apenas a busca de conforto espiritual ou ligação com as forças superiores orientadoras das práticas humanas, como tradicionalmente é pensado, quando se fala de religião. Nas religiões de tradição africana, o culto a essas divindades (orixás), através de narrativas míticas e de uma Pedagogia negra iniciática, dá origem aos valores e princípios sociais que devem sustentar a prática cotidiana dos seres humanos que participam da comunidade (LUZ, 2000, p. 45). Esses princípios são, pois, de caráter sócio-cultural, fundados numa explicação de natureza mítica.

Nessa perspectiva, o mito, nas comunidades religiosas de tradição africana, é compreendido como narrativa que possibilita o contato com valores, sentimentos, emoções e imagens simbólicas que constituem a própria experiência humana dos sujeitos que o narram e o tomam como caminho de estruturação da vida individual e coletiva. A narração mítica mostra aos sujeitos a sua própria condição humana no mundo, favorecendo refletir e orientar as suas ações. O mito também sugere modos particulares de sustentação e produção do grupo social que o produz, pela "[...] diversidade de modos de tratar e expressar aspectos básicos da existência humana." (SILVA, 1995, p. 319).

O mito, nas comunidades de tradição africana na Bahia, assume centralidade e se organiza a partir da compreensão citada anteriormente. Segundo Silva (1995, p. 318): “[...] a maneira como a cultura ocidental construiu, através dos séculos, algumas idéias dominantes a respeito de si mesma e dos demais povos do mundo, estabeleceu uma oposição entre mito e ciência que tinha por critérios a racionalidade e a capacidade de atingir a verdade." Essa compreensão favoreceu a construção de conceituações do mito 
como "narração mentirosa", "fantasiosa", "ilusão" produzida por mentes pouco evoluídas de povos em estado primitivo. $\mathrm{O}$ mito deveria "cair por terra" para ser substituído pela verdade. Afinal é muito fácil de ser desmascarado como irreal. Em oposição a essa compreensão, nas comunidades de tradição africana, o mito é forma, método privilegiado de pensar e manifestar suas concepções de mundo. Essas comunidades entendem que as narrativas míticas também são formas "verdadeiras" de pensar o mundo.

Compreendido como um dos métodos de transmissão da tradição africana, o mito pode ser também assim definido: “[...] nível específico de linguagem, uma maneira especial de pensar e de expressar categorias, conceitos, imagens, noções articuladas em histórias cujos episódios se pode facilmente visualizar." (SILVA, 1995, p.324). Os mitos africanos sempre dizem algo importante e devem ser levados a sério. Eles participam da produção da existência dos povos que os aceitam como "verdade". Para Jesus e Brandão (2000, p.54): “[...] o mito é o patrimônio cultural de um povo, constituindo-se num elemento de coesão social, de agregação e, em conseqüência, preservando-lhe a identidade [...] está profundamente enraizado no seu tecido social [...]"

Um dos recursos básicos do mito é a metáfora. De acordo com Silva (1995, p. 324):

Com Levi-Strauss, firmou-se a convicção de que a matériaprima com que as histórias que os mitos contam são construídas, são signos retirados de outros sistemas de significação, como as palavras da própria língua que, no contexto particular constituído por cada mito, adquirem novos sentidos; como, também, os elementos muito concretos da natureza (os astros, as interpéries, os animais, as plantas, as montanhas, os rios, o céu, os cheiros, os sabores); e, ainda, como experiências muito palpáveis da vida em sociedade (o parto, a morte, o sexo, a troca, a roça, a caçada, os filhos, as mães, os parentes) e das relações entre as pessoas (o comportamento, a obediência, a traição, a generosidade, a mesquinhez, a inveja). 
O mito é uma forma de explicação da existência humana, através de caminhos trilhados diferentemente daqueles propostos pela ciência ocidental. Sua explicação é metafórica, é poética, carrega consigo estética e "verdades" próprias.

\subsubsection{Princípios fundadores da infância afrodescendente}

Alguns princípios revelados pela narração mítica, centrada na figura dos Orixás ${ }^{8}$, e que possibilitam uma significativa construção de ser humano - neste contexto, a criança afrodescendente - serão aqui considerados. Para isso, é importante a conceituação dessas divindades. Segundo Siqueira (1998, p.42):

[...] são ancestrais simbolicamente divinizados [...] Sua presença se manifesta sob diversas formas na vida cotidiana das pessoas e da cidade. Historicamente os orixás vêm da África negra. Ali se estabeleceu a diferença entre um antepassado e um orixá, de acordo com o culto exercido, seja ele particular ou público. O antepassado da família foi honrado pelos seus em seu próprio espaço. O orixá transcende o círculo da família. Pertence a um determinado povo, que o reconhece como ancestral. Os adeptos se reúnem ao seu redor, a fim de celebrar um culto público. Os orixás têm a função de intermediários entre o grupo que representa e o Deus supremo longínquo, no qual o referido grupo acredita.

Os orixás, através da linguagem mítica, sugerem a incorporação de alguns valores e princípios fundamentais à prática humana ${ }^{9}$, estruturantes dos grupos étnicos Jeje-nagô vindos da África. Mantêm viva a experiência vivida em África, reorganizando-a e recriando-a em território baiano. Essas divindades, segundo Machado (1999), são vistas como modelos de identidade para a vida pessoal dos indivíduos. Suas características fundamentais são comparadas às pessoas.

- O princípio da reconciliação

Este princípio (organizador inicial dos terreiros), fundante da tentativa do negro africano e de seus descendentes de manter 
o vínculo que une corpo e território enquanto cultura, mediados pela memória, revela a valorização permanente da experiência cultural vivida como organizadora do sujeito. A memória, enquanto atividade mental, é o vínculo que liga esse sujeito à experiência produzida na África e aos seus ancestrais, com abertura suficiente para recriações contextualizadoras (danças, musicalidade, tradição), considerando o novo espaço (Bahia) e as novas formas de relações sociais e culturais (grupos étnicos africanos distintos, relações interétnicas no novo território, condições de escravidão e exclusão social).

- O princípio da integração e dos novos padrões de convivência: Iansã ou Oyá

Oyá está relacionada ao vento, ao fogo, ao relâmpago, à floresta e à terra. É o orixá integrador desses vários elementos na dinâmica da vida. Vida que só é possível, quando se consideram os princípios da ancestralidade e da descendência. Por integrar estes elementos à vida, acaba por viabilizar novos padrões de convivência dos seres humanos com a natureza e com eles próprios. Oyá é também o orixá que possibilita reconciliação dos membros do terreiro com os espíritos, principalmente os da floresta (LUZ, 2000). Neste sentido, possibilita o vínculo entre os ancestrais e seus descendentes.

\section{- O compartilhar: Oxum}

Segundo Siqueira (1998, p. 70), este orixá exerce influência sobre a "[...] fertilidade, a riqueza, a abundância. Com bastante determinação e ao mesmo tempo com simplicidade, ela é capaz de intervir com a palavra de paz em áreas de conflito, relativizando situações aparentemente delicadas." Apesar de ser portadora da riqueza, da fertilidade e da abundância, ela é capaz de compartilhar, sem reservas, todos os bens que possui. Valoriza o princípio feminino da existência. Possui relações 
íntimas com as águas correntes. Está, ainda, relacionada à procriação e é patrona da gravidez. "É ela quem cuida do desenvolvimento do bebê até que ele adquira a linguagem." (LUZ, 2000, p.63).

- O princípio da criação e da co-responsabilidade: Nanã e Oxalá

Nanã é considerada progenitora dos orixás, de existência marcada pelos princípios masculino e feminino. $\mathrm{Na}$ Bahia, Nanã é colocada na mesma hierarquia que Oxalá e considerada sua mulher. Ambos representam o princípio da criação, visto que Nanã está vinculada às águas contidas na terra: terra e água são elementos básicos para a criação da vida e da força vital (SIQUEIRA, 1998). Já Oxalá (ou Obatalá), "o grande orixá", é aquele que está vinculado ao ar e é o responsável pela criação dos seres humanos e das árvores. $\mathrm{O}$ ritual para este orixá revela um ciclo que ritualiza a renovação, a expansão da existência e a recriação. "Oxalá é quem modela a lama da criação dos seres humanos, ele possui o título de Alamorere que quer dizer Senhor da boa argila." (LUZ, 2000, p. 76).

- A multiplicidade, a diversidade da vida, o rigor com simplicidade e delicadeza: Oxumaré e Nanã

Oxumaré é representado pelo arco-íris e pela serpente. É nobre, altivo e rigoroso, mas, por ser filho de Nanã, consegue manter essas características com delicadeza e simplicidade. Rege o princípio da multiplicidade da vida (múltiplos e variados destinos). "Carrega em seu corpo todas as matizes de cores, as múltiplas combinações do axé, variedades de existências." (LUZ, 2000, p. 73). 
- A força, a inteligência, a justiça e o rigor. Xangô e Oxossi

Xangô é o orixá da justiça. Tem fortes poderes sobre o fogo, sobre o raio e sobre o trovão. É poderoso e exuberante, solene, corajoso e perspicaz. Bom conselheiro e inteligente. Para Siqueira (1998, p. 61-62):

Os filhos de Xangô são, ao mesmo tempo, solenes, corajosos e perspicazes. Em geral, eles não se preocupam excessivamente com o futuro, cada dia tem seu brilho, seu esplendor e suas providências. Porém, eles sabem cuidar muito daqueles pelos quais se sintam responsáveis.

São portadores do dom de bons conselhos, estimulam a "ir adiante". Se alguém os consulta para saber que atitude deve ser tomada em face de problemas delicados, a palavra é enfrentamento.

São dotados de inteligência brilhante e de uma memória excepcional, o que lhes assegura o direito de serem notáveis em seus domínios. Têm predileção por beleza, brilho e perfeição, e são especialmente rigorosos no que se refere às práticas rituais.

A partir do momento em que defendem uma causa, tornam-se apaixonados, possuem um sentido agudo de suas responsabilidades com o terreiro e os Orixás. Não são convencionais. Por outro lado, são capazes de grandes gentilezas e generosidade.

Já Oxossi é muito estimado nos terreiros baianos. É conhecido pela nobreza do seu caráter, que articula seriedade intelectual, grande inteligência, competência, habilidade verbal e muito comprometimento com as causas que defende, sem perder, em nenhum momento, a alegria, que é sempre contagiante. É o orixá do crescimento e da pesquisa, capaz de sempre ampliar os limites do conhecimento (SIQUEIRA, 1998).

- O acolbimento: Ibeji

São os orixás gêmeos, populares na Bahia por suas festas com caruru. São extremamente acolhedores e incluem as crianças 
como muito bem-vindas às suas festas. Gostam de compartilhar o alimento.

\section{- O respeito à natureza: Ossanyin;}

É o patrono da vegetação, das folhas, das ervas e dos remédios e preparos rituais e medicinais (LUZ, 2000). Para a filosofia nagô, há íntima relação entre medicina e religião. É através da natureza que os remédios para os males serão encontrados. Por isso, o respeito e a boa convivência com a naturez̧a são premissas fundamentais na organização da vida das pessoas do terreiro. As folhas também exercem papel muito importante nos rituais sagrados. Segundo Luz (2000, p.58): “O poder das folhas interliga as funções do Babalawo com a do Babalossaiyyn, isto é, do sacerdócio dos mistérios do destino com o do mistério das folhas, que promovem restituição e reforço de axé."

Esses são alguns valores e princípios trabalhados cotidianamente nas comunidades religiosas de tradição africana, na tentativa de validá-los na prática de vida individual e coletiva dos afrodescendentes na Bahia.

Considerando a nossa questão "O que é isto - A criança afrodescendente?", podemos afirmar que essa criança possui multiplicidade cultural, visto que descende de negros vindos de várias regiões da África e de etnias diversas. Sua origem revela uma identidade multicultural. No caso baiano, entretanto, incorporou maiores influências do grupo étnico jeje-nagô. Essa criança, que vive a experiência dos terreiros de Candomblé, produz conhecimento que valoriza os princípios já citados em sua constituição de vida: a reconciliação, a multiplicidade, a diversidade, o acolhimento, a força, a inteligência, o rigor (com delicadeza), o respeito à natureza, a coresponsablidade nas ações e a integração. Esse conhecimento e experiência, no entanto, encontram barreiras para serem validados fora dos terreiros, principalmente na escola, visto que esse espaço ainda perpetua uma racionalidade moderno-ocidental que exclui as várias possibilidades culturais de existência. Neste sentido, a identidade acaba por ser negada e/ou silenciada e, conseqüentemente, nega-se o direito à manifestação cultural. 
1.2.1.2 Criança afrodescendente: sujeito de direitos?

Os afrodescendentes na Bahia, apesar de salvaguardarem e reelaborarem a sua cultura de matriz africana, principalmente nos terreiros de Candomblé, no sentido social mais amplo ainda são negados e discriminados em vários espaços e situações. No relato de Oliveira (2003, p.18) fica claro que:

[...] os afrodescendentes foram alijados de sua terra de origem, por um lado, e menosprezados em suas terras de ocupação, por outro. Negados ontologicamente em qualquer parte do mundo, suas culturas foram rotuladas como atrasadas, animistas, folclóricas, bárbaras, primitivas, o que evidencia o racismo a que foram historicamente submetidas a população africana e seus descendentes. No Brasil, a teoria do branqueamento, a defesa ideológica da democracia racial, o ocultamento da realidade desfavorável aos afrodescendentes, denotam a falácia da convivência harmoniosa entre as raças $[\ldots]$

Nessa perspectiva, os direitos à manifestação religiosa de tradição africana, bem como a valorização individual e social de sua identidade continuam sendo negadas ainda hoje, em pleno século XXI, mesmo quando se instituem esses direitos por leis e decretos.

A construção real da infância afrodescendente, que se dá no cotidiano da sociedade contemporânea, contradiz a retórica estruturada a seu favor, expressa no Estatuto da Criança e do Adolescente (ECA), se considerarmos o que observamos na prática, por exemplo, da maioria das escolas públicas baianas. O conhecimento escolar desconsidera, tanto no plano epistemológico quanto no plano político do direito, a cultura do afrodescendente.

A observação do cotidiano alerta-nos para o fato de que a infância pensada pelos adultos que formularam o ECA ainda não corresponde à infância presente no cotidiano; ou seja, pensar a criança afrodescendente enquanto sujeito de direitos é, na contramão, assumir que essa criança está destituída deles. Dispõe o art. 17, capítulo II, Do direito à liberdade, ao respeito e à dignidade: 
"O direito ao respeito consiste na inviolabilidade da integridade física, psíquica e moral da criança e do adolescente, abrangendo a preservação da imagem, da identidade, da autonomia, dos valores, idéias e crenças, dos espaços e objetos pessoais." (BRASIL, 2003, p.3, grifo nosso). E no art. 18: "É dever de todos velar pela dignidade da criança $e$ do adolescente, pondo-os a salvo de qualquer tratamento desumano, violento, aterrorizante, vexatório ou constrangedor." (BRASIL, 2003, p.3, grifo nosso). Ao lermos esses artigos, percebemos a distância que separa o acordo entre retórica e real.

Dessa maneira, é interessante colocar em perspectiva a conceituação presente no ECA, quando responde implicitamente à nossa pergunta "O que é isto - A infância Afrodescendente?" Para o ECA, a resposta é: Sujeito de Direitos. Direito a ter sua identidade preservada, seus cultos respeitados, sua origem, crenças e valores. $\mathrm{E}$, diferente da etimologia da palavra, ela já possui um lugar na retórica político/social/histórica. O ECA chegou a essa definição a partir de alguns acontecimentos que o precederam e possibilitaram trazer à luz a formulação desse conceito.

Assim, no contexto moderno, séculos XVII e XVIII, segundo análise de Marcílio (2004), com o movimento progressivo de emancipação do homem e da mulher, dá-se a formulação dos Direitos Naturais do Homem e do Cidadão. A partir dessa discussão, incorpora-se também a discussão sobre os direitos humanos, direitos de liberdade, direitos políticos e civis. Num segundo momento, direitos de igualdade ou, como hoje conhecemos, direitos econômicos, sociais e culturais. Discussões mais recentes (final do século XX e início do XXI) referem o direito ao desenvolvimento, ao meio ambiente, à paz, à democracia e o direito dos consumidores. O direito à democracia é condição fundamental para a concretização dos Direitos Humanos.

No dia 10 de dezembro de 1948, foi divulgada a Declaração Universal dos Direitos Humanos, que tinha como objetivo maior 
atingir o homem todo (numa visão integral) e todos os homens social e politicamente situados, no sentido da felicidade e do bemestar (MARCÍLIO, 2004). Nessa perspectiva, subordina o privado ao público, valoriza a família, a comunidade, interesses, aspirações e necessidades sociais. Põe em debate a ética da verdadeira condição de cidadão extensiva a todos os homens, incluindo a criança. Nesse horizonte, aprofunda-se o direito à cidadania, o qual se preocupa com as responsabilidades que possam garantir ao homem, à mulher e à criança sua participação integral na sociedade.

A infância, nesse percurso, é valorizada em suas especificidades. A formulação de direitos específicos (compreendidos como especiais) passa a ser tarefa necessária. Em 1923, os princípios dos direitos das crianças foram defendidos pela organização não-governamental International Union for Child Welfare. Em 1924, a Liga das Nações (reunida em Genebra) assumiu também esses princípios e apresentou-os na primeira Declaração dos Direitos da Criança. Marcílio (2004, p.2) cita esses princípios:

1. a criança tem o direito de se desenvolver de maneira normal, material e espiritual; 2 . a criança que tem fome deve ser alimentada; a criança doente deve ser tratada; a criança retartada deve ser encorajada; o órfão e o abandonado devem ser abrigados e protegidos; 3. a criança deve ser preparada para ganhar sua vida e deve ser protegida contra todo tipo de exploração; 4. a criança deve ser educada dentro do sentimento de que suas melhores qualidades devem ser postas a serviço de seus irmãos.

Nessa trajetória de defesa pelos direitos das crianças, surgiu, no dia 11 de outubro de 1946, o United Nations Internacional Child Emergency Fund (UNICEF), com a intenção de socorrer as crianças dos países devastados pela $2^{a}$ guerra. Recebeu o apoio do Fundo Internacional de Ajuda Emergencial à Infância Necessitada, organismo criado pela Organização das Nações Unidas (ONU).

Mas foi em 1959 que a infância ganhou, de fato, atenção especial com a Declaração Universal dos Direitos da Criança. Os prin- 
cípios que a fundamentam são três: Universalidade, Objetividade e Igualdade (MARCÍLIO, 2004). É com esta declaração que a criança é pensada (e definida) como sujeito de direito e prioridade absoluta. A partir desses princípios, a criança tem direito à sobrevivência, proteção, desenvolvimento e participação. A exploração e o abuso contra ela devem ser combatidos.

Em 1989, foi publicada a Convenção das Nações Unidas sobre os Direitos da Criança. São direitos consagrados nessa convenção: direito a um melhor padrão de saúde, sobrevivência e pleno desenvolvimento; é criança (ou adolescente) toda pessoa menor de 18 anos; direito à verificação de seus melhores interesses; toda criança pode expressar seu ponto de vista e pode receber informações; ser registrada após o nascimento, ter um nome e uma nacionalidade; tem direito de brincar e receber proteção contra exploração sexual e abuso sexual. Em 1990, foram incorporados a esses: atenção à criança ou adolescente em conflito com a lei; direito ao desenvolvimento integral; apoio à família; e esforço pela distribuição de recursos mais eqüitativos.

O debate sobre os direitos da Criança em nosso país ocorreu de maneira intensa desde 1987, com a criação da Frente Parlamentar Suprapartidária. Governo e sociedade garantiram, em 1988, em três artigos da Constituição - 227, 228 e 229 -, um "lugar" para a criança na história (ou no discurso?). Esses artigos impulsionaram a formulação do ECA, assinado em 1990, que revogou o Código de Menores, bem como a lei que criou a Fundação Nacional do Bem-Estar do Menor (FUNABEM). Em 12 de outubro de 1991, foi criado o Conselho Nacional dos Direitos da Criança e do Adolescente (CONANDA), responsável pela implementação do ECA. Em 1993, o Programa Nacional de Atenção Integral à Criança e Adolescente (PRONAICA) foi criado pelo Ministério da Educação. Esses órgãos são responsáveis pela viabilização do cumprimento do ECA (MARCÍLIO, 2004). 
Considerando esse percurso de valorização da infância e garantia de seus direitos, em 10 de maio de 2002, o UNICEF informou que a ONU havia finalizado sua Sessão Especial da Assembléia Geral das Nações Unidas sobre a Criança com um acordo unânime feito por representantes de 180 nações, que se comprometeram em assumir quatro prioridades básicas para a infância: promoção de vidas saudáveis; promoção de educação de qualidade; proteção contra abuso sexual, exploração e violência; e combate ao HIV/AIDS (UNICEF, 2004).

Como afirma Marcílio (2004), em termos legais, o Brasil

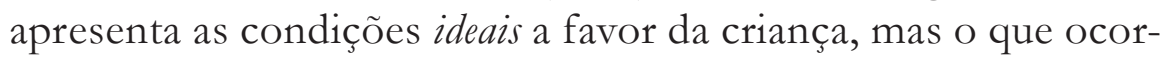
re na prática é a violação de seus direitos. Ainda assim, o que se tem na realidade brasileira, enquanto conceituação de infância, em sua abrangência, é a idéia de criança como sujeito de direitos. $\mathrm{O}$ que nos cabe, então, é validar, no cotidiano, o acordo entre retórica e ação e, mais importante ainda, discutir filosoficamente possibilidades de formação dos adultos (em especial dos educadores do ensino fundamental) que atuam junto a essas crianças, para que se tornem capazes de compreender, no caso da criança afrodescendente, a necessidade de valorizá-la em sua cultura, sua identidade, seus valores e cultos. 



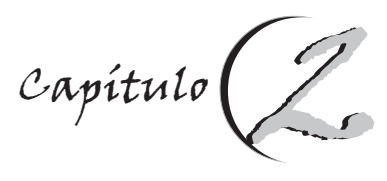

\section{EPISTEMOLOGLA, EDUCAÇÃO E INFÂNCLA AFRODESCENDENTE NO HORIZONTE DA CONTEMPORANEIDADE}

Não tendo me contentado com as ciências que nos eram ensinadas, percorri todos os livros que tratavam daquelas que são consideradas as mais curiosas e mais raras.

Descartes (2002, p.78)

\section{A}

rticular pensamento sobre Educação, Epistemologia e infância afrodescendente parte da intenção de dialogar com a construção do cenário escolar em sua cotidianidade, a partir do sistema de idéias que estruturam o conhecimento científico produzido nesse espaço. A inquietação de Descartes, destacada na epígrafe deste capítulo, em muito se assemelha às nossas motivações reflexivas; no entanto os caminhos percorridos divergem consideravelmente, já que a teorização deste filósofo é alvo de reflexão de natureza crítica nesta obra, que repensa o maior fundamento da ciência cartesiana. Nesse caminho, e paralelo a essa compreensão, não nos interessa sugerir um outro sistema fechado para a Ciência da Educação. O que nos agrada é a possibilidade de pôr em discussão aquilo que parece ser problemático.

Sendo assim, é importante abrir uma abordagem que possibilite uma leitura mais compreensiva do experienciar humano no cenário escolar contemporâneo, através de veredas discursivas validadas, principalmente, a partir do lugar da razão no projeto moderno 
que supervaloriza o cogito, especialmente a partir de Descartes. Essa "razão" moderna institui algumas separações, dentre as quais destacamos a separação entre sujeito cognoscente e objeto, fundamento da ciência positiva e funcionalista. Observe no Esquema 3, a seguir, a representação desta separação:

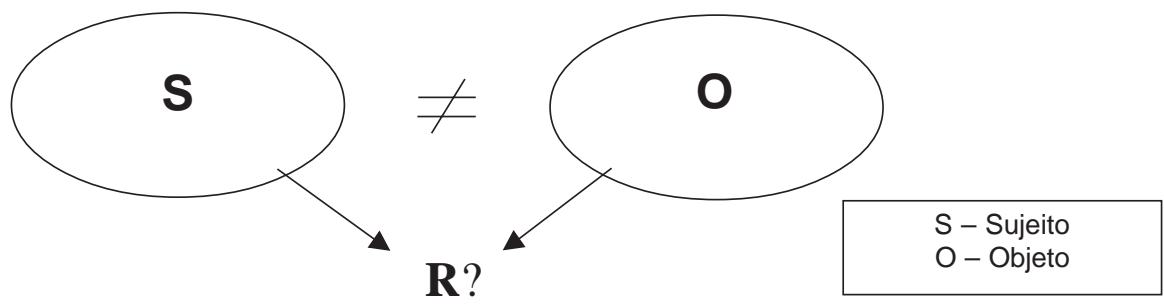

ESQUEMA 3

Relaç̃̃o Sujeito/OBjeto

A partir desse fundamento, as conseqüências para a formação do ser humano são muitas. Ele se separa da natureza, se separa de si mesmo, se objetiva, produzindo uma razão cognitivo/instrumental, supervaloriza a lógica das verdades absolutas e esmagadoras a favor de um discurso linear e ordenado ${ }^{10}$. Uma dessas verdades é a linearidade também no sentido da conceituação de humanidade: é humano o adulto/branco/europeu. Conseqüentemente, a Ciência é aquela elaborada a partir dessa ótica. O discurso linear não comporta as descontinuidades, por isso fortalece a exclusão de outras etnias e de suas produções culturais.

A humanidade, em sua construção ocidental, assumiu como referência a experiência do europeu, desde a antiguidade, como aquela que nos permitiria a evolução. Trata-se, portanto, de uma visão etnocêntrica, que produz julgamentos do que é belo e bom, considerando a sua produção cultural como qualitativa e quantitativamente 
melhor em detrimento de outras possibilidades que se apresentem. Esta postura acaba edificando sistemas de negação e desvalorização da própria condição de humanidade desses outros diferentes. Para Santomé (1995, p. 163):

O etnocentrismo consiste, pois, em julgar como "certo" ou "errado", "feio" ou "bonito" "normal" ou "anormal" os comportamentos e as formas de ver o mundo dos outros povos a partir dos próprios padrões culturais [...] pode consistir numa desqualificação de práticas alienígenas, mas também na própria negação da humanidade do outro.

Para Lévi-Strauss (1976), a diversidade das culturas, principalmente para o ocidente, revelou-se monstruosa ou escandalosa e por isso justificável para as posturas etnocêntricas. O autor considera que a atitude mais antiga do ocidente consistiu em repudiar as formas culturais, sejam elas religiosas, morais, estéticas, sociais, porque eram as formas com as quais o ocidente (branco, europeu, masculino e adulto) não se identificou, denominando-as de hábitos selvagens, sempre comparando com as suas próprias experiências. Expressões como $\mathrm{Na}$ minha terra é diferente, não se deveria admitir isso, eram agressivas, desqualificadoras e traduziam o calafrio de repulsa frente a outras formas de viver, pensar e crer que pareciam muito estranhas para o moderno ocidente.

A experiência do ser humano não deve ser reduzida a uma única possibilidade interpretativa e cultural, muito menos a modelos que sugerem ou aprofundam a dicotomia dele próprio com o mundo.

Considerar, então, a afrodescendência a partir da produção africana no contexto baiano, manifestada principalmente nos espacos sagrados ou terreiros de Candomblé, como uma das possibilidades interpretativas do conhecimento científico que é produzido no cenário escolar, é horizonte possível de enfrentamento da relação razão e experiência. É preciso uma abertura na explicação do humano, no contexto escolar, não como um ser já dado, forjado a 
partir de negações (étnico, culturais, sociais...), mas que o coloque em um caminho dinâmico que valorize a experiência humana no mundo, na sua completude e complexidade.

Desconstruir a idéia do conhecer separada do contexto da vida e da experiência em sua dimensão étnica é o desafio posto para a escola contemporânea e a ciência aí produzida. Esse cenário, por também estar edificado em bases modernas, apresenta uma gramática social, na qual as relações estabelecidas se fundam ainda num código dominante e, portanto, de poder, que sugere a reprodução de formas de pensamento que mantêm o status quo. Por isso, também exclui grupos que não apresentam as condições políticas, econômicas, religiosas e estético/culturais iguais às do grupo dominante.

A modernidade e suas elaborações no plano científico constituem nosso ponto de partida para entender a criança afrodescendente, explicada a partir de sua constituição étnica e de suas relações com a produção de conhecimento na dinâmica escolar contemporânea. Isto porque, como reflete Heidegger (2002, p.45): "[...] o tempo é o ponto de partida [...] o tempo como horizonte de toda compreensão e interpretação do ser."

Diante dessas reflexões, é necessário, inicialmente, aprofundar o pensamento no sentido de tentar compreender o processo de produção de conhecimento da criança afrodescendente no cenário escolar, especialmente no Ensino Fundamental. Para isso, considerando a dialética da relação educandos/educadores, é importante colocar em perspectiva a epistemologia que parece organizar a formação dos educadores desse nível de ensino. Nessa análise, na condição de educadora, estamos implicadas no processo que produz conhecimento nesta escola moderna. $\mathrm{O}$ valor da experiência vivida nos concede o direito de tentar articular um pensamento favorável também no sentido de possibilitar articulações e não as separações, no sentido cartesiano, já apontadas. 
O sistema de idéias que edifica a Ciência, valorizada pela maioria de nós, educadores do Ensino Fundamental, apresenta os mesmos elementos constituidores da Ciência moderna; ou seja, temos a certeza de que o educando vai à escola construir conhecimento, como se fora dela já não acontecesse esse processo, e que essa construção ocorre a partir do aspecto cognitivo/biológico. A crença na razão como fonte segura do conhecimento organiza essa produção. Sendo assim, objetivamos as crianças, enquadrando-as num modelo que permitirá, para usar a linguagem corriqueira contemporânea no cenário escolar, socializar saberes culturais, sociais, históricos, emocionais, enfim, o pano de fundo ainda é a preocupação com os conteúdos a serem racionalmente e linearmente transmitidos. A cisão entre pensamento e ação (vida), sujeito e objeto está posta e é hierarquizada. Note, no Esquema 4, a representação gráfica desta separação:
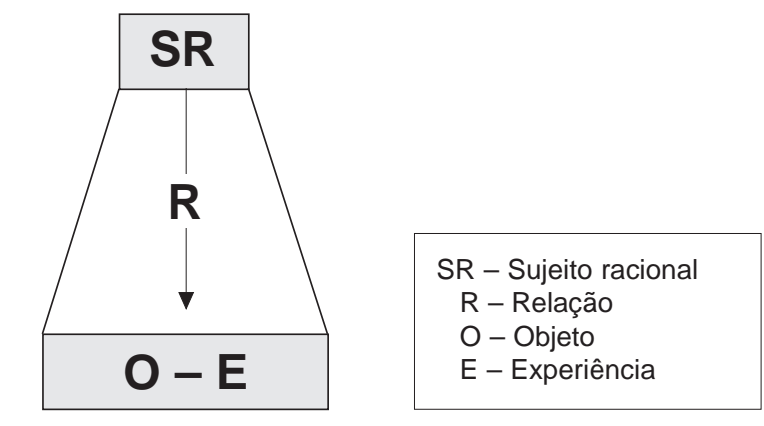

\author{
ESQUEMA 4 \\ Separação Sujeito Racional e Objeto/Experiência/ \\ Hierarquia na Relaç̧̃o
}

Essa supervalorização da razão apresenta-se principalmente a partir da interpretação acerca da Epistemologia Genética, tão difundida e banalizada no Ensino Fundamental, na qual a idéia organizadora é a de que produzimos conhecimento, tendo como aspecto fundante a cognição. Sendo o conhecimento um dado 
cognitivo, não há necessidade de preocupação com aspectos étnicos, políticos, econômicos e sociais para ele ocorrer. Isto porque a cognição é entendida como manifestação igual em todos os sujeitos. Daí a universalização. Forjamos, portanto, um contexto também universal que rompe com a vida dos educandos. Nesse sentido, a separação sujeito/objeto encontra na escola contemporânea seu cenário de validação, já que a cisão entre ser e mundo se aprofunda nesta escola de configuração moderna. Essa necessidade de universalização é um dos critérios da ciência moderna que homogeiniza o ser humano e a cultura. De forte tendência autoritária, essa universalização já não consegue contemplar a diversidade, a experiência dos vários sujeitos que participam e constroem o espaço escolar.

Articulada a esta visão, como a metafísica ocidental ainda é assumida como referência na escala evolutiva, progressiva (e por isso também assumimos como referência de humanidade o branco europeu como "maiores produtores" dessa Ciência), outras vias possíveis de produção de conhecimento não são consideradas. A tradição afrodescendente, nesse sentido, ocupa lugar marginal, porque está separada da constituição do ser criança no Ensino Fundamental, em razão das formas de pensar as relações entre sujeito e objeto por parte dos educadores, bem como devido às práticas etnocêntricas no sentido da valorização, ainda muito presente no cotidiano escolar, do branco-europeu como exemplo de evolução, desenvolvimento/progresso e beleza. Com esta afirmação, não abrimos aqui um discurso de negação da cultura branco-européia; o que colocamos em perspectiva é a necessidade de dialogia e valorização das várias culturas, fato muito negligenciado no contexto educativo.

Nesse sentido, a possibilidade de pensar um conhecimento de natureza científica, produzido a partir da situação étnica (na consideração de alteridade) dos sujeitos é idéia, na maioria das vezes, descartada. Na Escola Fundamental contemporânea, a ciência é universal e o conhecimento produzido a partir de sua via também. 
A universalidade dos sujeitos é fato complicador no caminho do pensamento que sugere uma epistemologia de natureza crítica e aberta às possibilidades. A separação instituída entre educando (o que conhece/sujeito) e o que será conhecido (objeto) é aspecto que revela a compreensão de ciência fundante do ensino fundamental.

Uma revelação dessa compreensão se explicita quando tomamos como referência para reflexão e problematização a produção de conhecimento das crianças que cultuam o Candomblé. Citamos como caminho de reflexão uma situação concreta. As relações estabelecidas entre a escola e o conhecimento dos sujeitos que praticam o Candomblé são reveladas por Josenilda (confirmada como Ekédi no terreiro Ilê Axé Oxumaré):

$\mathrm{Na}$ bora da obrigação tem que tirar o contra-egum para ir pra escola [bracelete de palha carregado de significado religioso e cultural]. Foi o que aconteceu com uma das crianças que pratica a religião. Ou tira o contra-egum ou não vai ou então só faz a obrigação na época das férias por causa da discriminação. Quando... [cita o nome da criança] foi à escola, a professora, de religião protestante, viu o contra-egum e já tinha perguntado o que tinha acontecido com o cabelo dela [raspado por causa da obrigação religiosa], logo a mesma inicia discurso desqualificador e ao final pergunta para a classe: Nós somos filhos de Deus e ... [diz o nome da criança] é filho de quem...?

Este relato desvela a incapacidade de a Escola considerar o ser humano em sua constituição efetiva de vida, enquanto presença. Essa criança se transforma em um ser abstrato na escola; é obrigada a se separar do conhecimento vital exercido fora do domínio escolar, silencia, se esconde e é forçada a se enquadrar num discurso universal e excludente.

É preciso, portanto, compreender a criança afrodescendente em sua cotidianidade, no mundo, no dinamismo que a vida sugere, a partir de sua situação étnica. Etnia que se faz enquanto aconte- 
cimento multifacetado, multiforme, complexo, plural. Afinal, concordamos com Castells (2002), quando afirma que a identidade é processo de construção de significados e experiências de um grupo com base em atributos culturais interrelacionados que prevalecem sobre outras fontes de significados, sem excluí-las. Esse grupo tem nome, idioma, cultura e, de alguma forma, se constrói a partir do jogo tensivo de distinção e relação entre eu e outro, nós e eles. Nesse sentido, identidade é autoconhecimento enquanto construção que está relacionada à necessidade de ser conhecido também pelos outros. Utilizamos a metáfora da casa de espelhos, referida por Ponczek (2003), na qual o autor explicita que o sujeito, quando olha para si, o faz com olhar multiplicado, considerando os outros olhares em sua elaboração.

Compreender a criança afrodescendente como presença, é entendê-la enquanto corporeidade viva no mundo, como Ser em busca de esclarecimento sobre si, em seu sentido ontológico, a partir das relações tensivas (e conflitivas) com o outro. Da relação ser-mundo, o ser-aí, o Dasein heideggeriano, brota uma outra de natureza triádica, ser-mundo-conhecimento. Conhecimento, que em francês significa connaissance, ou seja, nascimento do Ser, é entendido como erguer-se e mostrar-se ao pensamento. $\mathrm{O}$ pensamento faz com que o Ser se conheça e se presentifique. O conhecimento aqui é descrito não a partir da visão metafísica produtora do sujeito que conhece ou sujeito consciente. No sentido ontológico heideggeriano, o conceito de Ser no vazio e abstrato, resultado da lógica formal escolástica, deve ser repensado e, em seu lugar, a partir do método fenomenológico, o Ser deve se dar a conhecer imediatamente, na e pela experiência.

O Ser ontologicamente pensado, segundo defesa heideggeriana, coincide com presença, não com sujeito consciente. Do mesmo modo, o sentido de mundo difere do sentido de objeto. Essa relação cindida entre sujeito, objeto e conhecimento, posta pela 
metafísica, dificulta nossa compreensão do Ser criança afrodescendente. Para nós, não deve existir corte no processo de conhecimento. Heidegger (2002, p. 98) afirma:

Se o ser-no-mundo é uma constituição fundamental da presença em que ela se move não apenas em geral, mas, sobretudo, no modo da cotidianidade, então a presença já deve ter sido sempre experimentada onticamente. Incompreensível seria uma obnulação total, porque a presença dispõe de uma compreensão ontológica de si mesma, por mais indeterminada que seja, e logo que o 'fenômeno do conhecimento do mundo' se apreende em si mesmo, sempre recai numa interpretação formal e 'externa'. Um índice disso é a suposição, hoje tão corrente, do conhecimento como uma 'relação de sujeito e objeto', tão 'verdadeira' quando vã. Sujeito e objeto porém, não coincidem com presença e mundo.

Veja no Esquema 5, a seguir, a representação da relação sujeito-objeto tal como concebida por Heidegger:

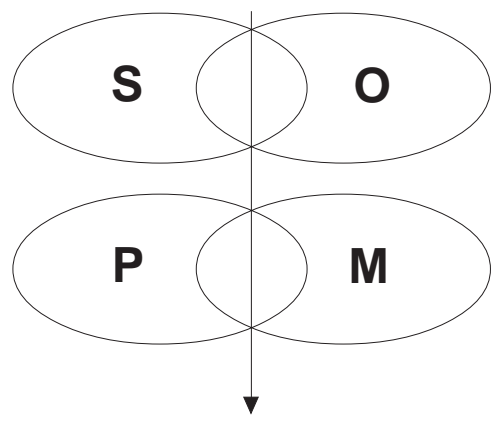

$\mathrm{S}-$ Sujeito

O - Objeto

$\mathrm{P}$ - Presença

$\mathrm{M}$ - Mundo

R - Relação

\author{
ESQUEMA 5 \\ RelaçÃo Sujeito/Objeto $=$ Presença $/$ Mundo
}

Afirmar que sujeito e objeto coincidem com presença e mundo seria o mesmo que afirmar que entre presença e mundo há um acordo solidário, a partir do qual a criança afrodescendente deveria se 
constituir também na escola. Ou seja, pensar a partir do seu próprio Ser situado na dinâmica do mundo. Para isso, a sua religiosidade, musicalidade e manifestação corpórea precisam ser considerados.

No entanto, percebemos que essa mesma criança, ao chegar na escola, deve se enquadrar em uma lógica de pensamento que se separa da vida, no sentido da mundanidade, e deverá levar para o campo da abstração os sentidos das coisas efetivamente vitais. A crença na possibilidade de que o mundo possa ser conhecido mediante projeções de construções de outrem fortalece a compreensão de que o mundo é separado da pessoa, do seu corpo contextualizado, tornando-se pura abstração. Nesse sentido, Descartes (2002, p.41) fortalece esse argumento: "Mesmo que este [o corpo] nada fosse, ela [a alma] não deixaria de ser tudo aquilo que é." Com essa afirmação, está postulado o corte entre o eu pensante e o corpo, fundamento principal da antropologia cartesiana. E é nessa perspectiva que a Epistemologia fundante da prática do educador, no contexto escolar, concebe a criança afrodescendente. $O$ sentido dado à criança afrodescendente na escola tem suas bases fincadas numa epistemologia de natureza metafísica. Para alcançarmos esta compreensão, precisamos nos lançar na tentativa de mapear algumas construções relativas a esse conceito. Galeffi (2003, p.192-193) nos apresenta significativa descrição semântica:

[...] o termo "epistemologia" foi originalmente proposto em língua inglesa ("epistemology”), em 1954, sendo usado em oposição à "ontology" (ontologia), ou seja, significando a "teoria do conhecimento" em oposição à metafísica clássica como "teoria do ser". Entretanto há registro de seu aparecimento em língua francesa desde 1901, quando da tradução do livro de Bertrand Russell "Ensaio sobre os fundamentos da Geometria" (1894). Aí o termo "epistemologie" significa uma "filosofia da ciência", entenda-se, dos "fundamentos" da ciência, o que em francês é "epistemologie" se diz "philosophy of science".

Esse sentido ambíguo do termo epistemologia permite falar de dois usos predominantes: um continental e outro anglo-saxônico. 
O dado é que tanto o alemão como o italiano, usam o termo segundo os franceses, o que caracteriza um uso continental. Epistemologia, portanto, é para a cultura continental o mesmo que "filosofia da ciência" e para a cultura anglo-saxônica é o mesmo que "teoria do conhecimento".

Desse modo, assumimos o uso continental para tratar do conhecimento de natureza científica produzido pelo educador no cotidiano escolar. Essa epistemologia parece não estar dissociada do sentido etimológico sugerido originariamente pelos gregos, formada pela união de dois vocábulos: epistéme + logos (GALEFFI, 2003). Considera Heidegger (1996) que Epistéme deriva do particípio epistámenos, e dessa forma se chama o homem que é competente e hábil. Significa saber, ser capaz, ser competente no fazer algo, ser versado em. Esta competência e este saber dizem respeito a um estado empírico, que é a reunião da experiência com a técnica, que resulta numa coisa prática, objetiva. É aquilo que resulta da técnica, da experiência. Uma atividade que passa de prática à teorética. Galeffi (2003) afirma ainda que desde a sua gênese, a filosofia relaciona epistéme com competência teorética, "pura abstração" e que essa compreensão está atrelada à visão grega de matemática (mathematokê), que para os gregos traduzia-se como técnica (technè). A síntese é a Ciência Matemática, que se traduz como o feminino de mathematikós, que é aquele que possui o conhecimento de ensinar grandezas, medidas, propriedades dos entes naturais aos humanos, o que resulta numa efetiva relação de transmissão: eu ensino. A autoridade do pensador acaba finalizando numa competência de objetivação e abstração dos fenômenos.

Por estar pautada nessa visão de conhecimento científico, a epistemologia do professor acaba por colaborar com a "objetivação", com o pensar o sujeito racionalmente constituído, empenhando-se em validar a tradição da ciência moderna, ainda que "inconscientemente" (para usar a linguagem da psicanálise). Mas é preciso saber, como diz Heidegger (1996, p.52), que "Nenhum modo de tratamento dos obje- 
tos supera os outros. Conhecimentos matemáticos não são mais importantes que os conhecimentos filológicos-históricos."

Como um dos resultados dessa postura, conquistamos o entendimento de que as idéias concebidas são os atores na maioria das situações escolares, enquanto os educandos incorporam essas idéias que irão produzir condutas e comportamentos universais. Deixamos, assim, de penetrar no "mundo vivo" propriamente dito. Essa idéia de razão pura acaba gerando aquilo que nomeamos como representações. O educando é, portanto, confundido com o ator que representa o mundo concebido como cenário, palco, onde as máscaras são postas. Ponczek (2003, p. 12), ao discutir essa separação instituída entre sujeito e mundo e as suas conseqüências, considera:

[...] entre o mundo e o homem, ergueu-se uma parede de vidro intransponível apartando-os, sendo oferecida ao homem apenas possibilidades de representações de um mundo que lhe é extrínseco e ontologicamente inferior e da qual apenas pode esboçar imagens representativas. É lhe vedada a porta de acesso ao mundo numênico, ou melhor, ao Ser, simplesmente porque o homem apartou-se do Ser.

A representação passa a ser o caminho assumido pelo sujeito, já que a ele é vedada a possibilidade de produzir a própria existência.

O vocábulo representação, em seu sentido originante medieval, indica imagem ou idéia, ou ambas as coisas. Seu uso foi sugerido aos escolásticos pelo conceito de conhecimento como "semelhança" do objeto. "Representar algo" - como dizia São Tomáz de Aquino - indica conter a semelhança da coisa. No entanto, foi no final da escolástica que esse vocábulo ganhou força e passou a ser mais utilizado, a partir dos seguintes sentidos: em primeiro lugar, designa aquilo "por meio do qual" se conhece alguma coisa. Em segundo lugar, representar é conhecer outra coisa após a efetivação de um conhecimento já dado, se, nesse sentido, a "imagem" representa o que deve ser conhecido, no ato de lembrar. Em terceiro 
lugar, o vocábulo é entendido como "causar o conhecimento" viabilizado objeto (ABBAGNANO, 2003).

Na primeira indicação, é a idéia no sentido mais geral; no segundo caso, é a imagem; no terceiro, é o próprio objeto. Estes são os possíveis significados do termo, que voltou a ter importância na modernidade, a partir da noção cartesiana de idéia como "quadro" e "imagem" da coisa. Foi difundido, sobretudo, por Leibniz. Já Kant estabeleceu seu significado muito geral, considerando-o gênero de todos os atos ou manifestações cognitivas, independentemente de sua natureza de quadro ou semelhança, e foi desse modo que o termo passou a ser usado em Filosofia.

Em Ciências Sociais (bem como na História e Psicologia), o uso do termo não diverge muito, visto que também indica certa ausência da existência humana em sua produção de conhecimento. A experiência do sujeito é invalidada, acovardando-o e favorecendo a alienação ideologicamente construída. O ser humano passa a viver por meio de idéias e sentimentos abstratos, acabados e inalteráveis, produzidos pela massa coletiva e pelas opressões sociais.

Segundo Moscovici (1978), representação social é um tipo de conhecimento muito particular, o qual apresenta como principal função a produção de comportamentos e também de comunicação entre os sujeitos, que resulta na elaboração de teorias sobre as coisas do mundo. Neste sentido, a representação social se autogere pelas teorias científicas, pela cultura, pelas ideologias formalizadas e das experiências cotidianas. Ela passa a se constituir num sistema interpretativo construído pelo indivíduo, sendo essa interpretação orientadora de condutas e comportamentos no meio social já, psicologicamente, interiorizados, conseqüência da experiência com os outros. O poder da representação acovarda o sujeito, que tem a sua liberdade de ser, sentir e pensar reduzida, em favor do que, de certa forma, já está instituído socialmente. 
Parece-nos que, ao deixar de perceber, no cotidiano escolar, que as idéias (racionalmente constituídas e representadas) passam a ser os "próprios sujeitos", o educador institui uma relação de enquadramento em leis, normas, verdades, regras ou determinações que acabam por afastar os educandos das possibilidades de produzir a própria existência.

Ao considerarmos essa situação, notamos que a criança afrodescendente deverá elaborar um caminho de integração a essa forma científica pensada no cotidiano escolar, porque, se é fato o que afirma Freire (1967), todo ser humano precisa se sentir integrado a um contexto. Ao entrar na esfera humana de integração, o ideal seria assumir as conotações de pluralidade, de transcendência, de criticidade, de conseqüência e de temporalidade, para não produzir situações hierarquizantes, dominadoras, reprodutoras. Enfim, Freire (1967) considera que as relações que os seres humanos estabelecem entre si e entre si e o mundo são intencionais e os tornam entes de relações. Ou seja, somos cultural e historicamente o fruto das relações objetivas e simbólicas que estabelecemos com os demais humanos e suas produções e também com a natureza. Então, como fruto da relação educador/educando pautada numa epistemologia de cunho metafísico, torna-se evidente que o educando produzirá o conhecimento projetado pelo educador.

Assim, pensar o que a criança afrodescendente é, como se forma, que conhecimento produz, é situá-la em relações objetivas e simbólicas nas quais está mergulhada. Na medida em que entendemos a escola como espaço que colabora com essa formação, seja revelada em suas práticas objetivadas, seja de maneira oculta, estamos paralelamente entendendo que é também na escola que a criança se situa, se integra e, a partir daí, passa a assumir implicação com o conhecimento valorizado e produzido nesse espaço. Significa dizer que, mesmo participando de um processo de formação humana anterior e/ou paralelo à escola, ao chegar a esse espaço, a criança participa de outro 
processo de enraizamento e integração que descaracteriza ou valoriza o anterior. Mas, enquanto espaço que conserva a racionalidade moderna, de fundamentos epistemológicos metafísicos, branco-ocidental, é também tutor do ajustamento. Segundo Freire (1967, p.42):

A integração ao seu contexto, resultante de estar não apenas nele, mas com ele, e não a simples adaptação, acomodação ou ajustamento, comportamento próprio da esfera dos contatos, ou sintoma de sua desumanização, implica em que, tanto a visão de si mesmo como a do mundo, não podem absolutizar-se, fazendo-o sentir-se um ser desgarrado e suspenso ou levando-o a julgar o seu mundo algo sobre o que apenas se acha. A integração o enraíza. Faz dele, na feliz expressão de Marcel, um ser "situado e datado". Daí que a massificação implique no desenraizamento do homem. Na sua “destemporalização”. Na sua acomodação. No seu ajustamento.

A partir dessa defesa, entendemos que a criança afrodescendente, quando chega à escola, inicia um processo de descaracterização ou desenraizamento étnico. Dessa forma, por precisar integrar-se e ajustar-se a esse mundo/escola, a criança assume os discursos e as práticas nela veiculados. Daí a importância de pensar a epistemologia do educador.

Insistir nos fundamentos da metafísica moderna favorece, por exemplo, aquilo que Bourdieu (2001) apresentou como caminho de elaboração do sujeito, no campo das representações sociais, ao discutir o conceito de habitus. Este é entendido como a "predisposição dos agentes sociais ao ajustamento" a partir da dialética interior/ exterior, objetivo/subjetivo, que os grupos realizam quando existe um princípio gerador e unificador do conjunto das práticas e ideologias características de um grupo de agente. Bourdieu (2001, p. 190) esclarece:

[...] habitus socialmente constituído, para que lhes ${ }^{11}$ tivesse sido possível ocupar as posições que lhes eram oferecidas por um determinado estado do campo intelectual e, ao mesmo tempo, adotar as tomadas de posição estéticas ou ideológicas objetivamente vinculadas a estas posições. 
Ou seja, se há hegemonia do conhecimento e dos modos de vida de um grupo sobre outros, aquele que está em posição de desvantagem ou desprestígio acaba se ajustando ou adquirindo o que antes era não-seu.

$\mathrm{O}$ que parece ocorrer no sentido da não consideração da criança afrodescendente em sua dinâmica de mundo, enquanto presença e relacionado à Epistemologia que constrói um sistema de idéias fechado em padrões modernamente constituídos, afeta aquela nossa defesa sobre alteridade. No cotidiano escolar, a alteridade é conceito ainda não percebido no corpo, nas ações, nas condutas, nos discursos. O que ocorre, ao contrário, são práticas e discursos a favor de um grupo humano dominante na história do Ocidente: o branco-europeu (e americano), mesmo que sutilmente percebidos.

Desde nossa moderna formação colonial brasileira, a linearidade a favor do branco quanto aos padrões de beleza, exemplo de inteligência e nobreza, se revela também na contemporaneidade. Os discursos, as condutas frente a atitudes de desqualificação étnica (seja no sentido físico, seja relativo às produções orais e escritas, tais como a exclusão dos mitos africanos e indígenas enquanto orientadores de pensamento a favor dos mitos greco-romanos como referencial de produção humana), os murais informativos e painéis decorativos com imagens de 90\% de crianças e jovens brancos, revelam ainda a nossa incapacidade de construir práticas fundadas na idéia de inclusão (e alteridade) dos outros diferentes daqueles hegemonicamente pensados.

É através desse habitus que a criança afrodescendente entra em sintonia com o educador metafísico. Incorpora pensamentos e padrões de conduta que reduzem a possibilidade de Ser e se revelar enquanto presença. Suas crenças, valores, cultura não estão contemplados na ciência da educação no Ensino Fundamental contemporâneo, nem mesmo quando se institui por decretos de lei que 
a História e cultura afro-brasileira na escola (Lei n 10.639, de 09/01/ 2003) deve ser ensinada. Mais uma vez, centramos no ensino racionalmente valorizado. Devemos ensinar, transmitir informações sobre esse tema, mas o discurso oculto, paradoxalmente, afirma que não devemos viver efetivamente esta experiência.

Enquanto produtora de habitus, a criança afrodescendente está impossibilitada de conhecer, visto que este verbo vincula o ser humano ao mundo. Afinal, se conhece algo ou alguém, porque o verbo conhecer precisa de um complemento. Conhecer está ligado a algo de que temos experiência direta ou pessoal. Conhecer indica uma convivência do falante com aquilo do qual ele fala (BOMBASSARO, 1992). O conhecimento, enquanto atividade intelectual, na qual o ser humano procura compreender e explicar o mundo que o constitui e o cerca, é resultado da ação conciliadora/interativa entre razão e experiência.

Se considerarmos o que aponta Heidegger (1996) sobre existência e vida cotidiana do ser humano, é possível compreendermos melhor o que ocorre com a criança afrodescendente quando realiza o babitus como atividade intelectual e prática na busca de fugir da opressão, silenciando e negando a própria existência. Segundo esse autor, a vida cotidiana se funda em três aspectos: a facticidade, a existencialidade e a ruina. Em sua dimensão de facticidade, o ser humano está jogado no mundo. Sua escolha não participa do contexto em que está inicialmente imerso. Sua vontade não interfere nas condições geográficas, históricas, sociais e econômicas, mas em seu processo de existencialidade (ou transcendência). O ser humano realiza atos de apropriação das coisas do mundo; ele existe à frente do próprio desejo e por isso pode se transformar naquilo que ainda não é. É um ser que se projeta para fora de si, mesmo sem sair das fronteiras do mundo em que está submerso. Projeção no mundo, do mundo e com o mundo. O eu e o mundo são inseparáveis. Mas o ser humano ainda pode entender-se como o Ser de ruína; ou seja, pode se desviar de seu projeto essencial em favor das preocupações e opressões cotidianas. Isto, entretanto, o destrói e o preocupa, 
confundindo-o com a massa coletiva e fazendo-o assumir a condição de aceitação passiva da realidade.

O eu individual é sacrificado pelo eles. O ser humano, em sua cotidianidade, é público e se reduz à vida com os outros e para os outros, alienando-se de sua principal tarefa: tornar-se si mesmo. As opressões sociais acovardam o ser humano - em nosso caso a criança afrodescendente - deixando-o cansado de si próprio, imerso na banalidade e no anonimato. Passa a viver por meio de idéias e sentimentos acabados e inalteráveis, exilado de si mesmo. Para encontrar o Ser, segundo Heidegger (1996), é preciso desvendar a existência autêntica. A criança afrodescendente precisa conquistar a sua autenticidade também na escola.

O habitus produzido pela criança afrodescendente compõe, na escola, sua dimensão de existencialidade. A essa criança é possível a ruína, mas também é possível a transcendência da condição dada. A dinâmica da vida escolar cotidiana é que vai possibilitar ou não a ruína. Nessa dinâmica, a epistemologia produzida pelo educador será também fator importante em seu processo existencial.

No processo, a criança enfrentará a angústia própria do ser para a morte heideggeriano. A angústia é o que pode reconduzir essa criança ao encontro de sua totalidade, já tão fragmentada e reduzida pela vida escolar pautada na racionalidade moderno/ocidental. A angústia possibilita a essa criança a superação da traição cometida contra si mesma (produção de habitus), que só favorece as opressões e as violências externas. A angústia, enquanto fenômeno de estranheza radical, tem sua fonte no próprio mundo e permite duas saídas: a primeira é fugir do novo e voltar para a vida cotidiana; a segunda é superar a angústia, manifestando poder de transcendência sobre o mundo e sobre si mesmo; é buscar as saídas. A partir dessa perspectiva, a criança afrodescendente pode encontrar as saídas, atribuindo um sentido a seu Ser. Ela está capacitada para isso. Deve se projetar sobre o mundo e mudá-lo. Na escola, entretanto, ela não está sozinha; ela está com o educador, o Ser é em-comum. 
Com essas reflexões, entendemos que é possível construir uma outra via de pensamento favorável a uma re-significação da epistemologia do educador, até então valorizada no cotidiano escolar, em favor de uma outra epistemologia, nomeada de Epistemologia Crítica, comprometida com o ser criança afrodescendente em sua constituição ontológica, em sua tarefa existencial. Essa epistemologia percorre caminhos diferentes daqueles trilhados pela metafísica ocidental. Trata-se de uma epistemologia re-significada, não linear e progressiva, capaz de considerar as descontinuidades, as subjetividades e os processos vitais humanos. Instaurar uma dimensão crítica na construção da epistemologia que funda a educação é uma das tarefas contemporâneas da escola.

Dessa forma, incorporamos ao discurso alguns princípios valorizados pela tradição africana, como possíveis elementos organizadores de uma Epistemologia Crítica. Diferente da construção Ocidental, que se revela nos caminhos da ciência em sua produção moderna, na qual o corte sujeito/objeto é um dos seus maiores fundamentos, a tradição africana na Bahia, através do princípio (ou fundamento) da reconciliação, valoriza a não dicotomia entre sujeito e experiência. Essa tarefa africana, de caráter muito criativo, rompe com a maneira cartesiana de pensar o sujeito. Observe o Esquema 6, a seguir, que representa graficamente o fundamento da reconciliação:

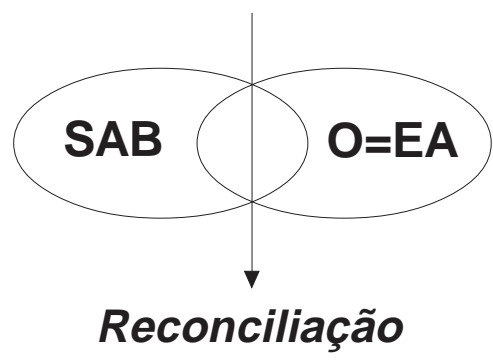

\begin{tabular}{|c|}
\hline SAB - \\
Sujeito \\
afrodescendente \\
na Bahia \\
O - Objeto \\
EA - Experiência \\
Africana
\end{tabular}

ESQUEMA 6

Sujeito Afrodescendente na Bahia - Reconciliação -

Objeto $=$ Experiência Africana (Cultural e Territorial) 
A necessidade de não se separar da experiência produzida na África, e ao mesmo tempo buscar novas formas de produção cultural, compreendendo o dinamismo dos contextos, no caso do território baiano, e a convivência com etnias diversas, é o contraponto da forma cartesiana de pensar o conhecimento e o ser humano.

A valorização dessa reconciliação, que podemos chamar de fundamento inicial da epistemologia crítica na formação do educador, seria muito significativa para todos os sujeitos que vivem o processo de educação formal, independente de serem ou não afrodescendentes. É a forma de compreensão e interpretação dessa relação repensada entre sujeito/objeto que poderia colaborar com a diminuição do autoritarismo, da desvalorização da experiência e do etnocentrismo presente nas práticas pedagógicas.

A forma de produzir conhecimento não fragmenta o Ser. O ser humano não se produz apenas a partir de sua dimensão cognitiva. Existem aspectos como a dança e a música que encaminham uma construção existencial de natureza complexa, no sentido de articular elementos definidores de uma vivência encarnada no mundo e que tem como pano de fundo uma história e uma cultura que busca não separar corpo e mente, cognição e vida produzida mediante os seus vários elementos (culturais, políticos, sociais, históricos). O respeito e a integração à natureza mostram que não deve existir uma autoridade do Ser frente ao mundo. As plantas e os animais têm grande valor material e simbólico e participam da existência de cada membro da comunidade afrodescendente. São elementos que compõem a existência, a vida dessa comunidade, ocasionando uma relação de interdependência. A natureza não é compreendida como objeto separado do sujeito, tal qual imaginou a ciência moderna. Essa compreensão acabou favorecendo grandes destruições no plano ambiental, devido ao afastamento, separação e poder de um sobre o outro.

Outros princípios, já citados no capítulo anterior, poderiam colaborar com a construção de uma Epistemologia Crítica. A consi- 
deração da diversidade, da multiplicidade e das descontinuidades numa relação de complementariedade rompe a defesa cartesiana estruturada pela crença de que é possível alcançar a verdade absoluta da realidade. Com essa posição, Descartes (2002) institui que a razão é universal e a priori. A tradição africana, em sua manifestação de religiosidade, assume implicitamente que os discursos não são falsos ou verdadeiros. Segundo essa visão, todos os discursos têm a sua validade e constroem a realidade. Por isso, a construção mítica também se funda na consideração de várias possibilidades discursivas. Vários orixás, cada um com um conhecimento válido, sem a preocupação moderna de construir um único saber universal, capaz de atingir a todos de maneira igual.

Cada orixá apresenta uma verdade que se articula a outras e compõem uma explicação para os fatos cotidianos. Por exemplo, se consideramos o orixá Nanã Buruku e os fundamentos de sua existência, notamos que ele se constitui a partir do princípio feminino (sincretizado com Mawu, ser supremo) e do princípio masculino (Lisa, ser supremo). A verdade não apresenta um único ponto ou oposições (masculino ou feminino, bom ou mal...). É sim, uma coisa e outra, é a possibilidade de não ser uno. Nanã tem em suas vestes grande quantidade de búzios que representam os duplos espíritos presentes nos seres humanos e nos ancestrais (LUZ, 2000). Oxumaré é também um exemplo significativo, já que é representado pelo arcoíris, que representa a própria diversidade de cores e caminhos. É ele que rege o princípio da multiplicidade da vida.

Estes princípios podem ajudar o educador a repensar o sistema de idéias pedagógicas, de natureza cartesiana, que conceituou o ser humano como um sujeito-sem-mundo, apartado da experiência, cercado pelos limites da razão. A evidência de que alguns princípios da tradição africana na Bahia colaboram com uma possibilidade de repensar os fundamentos da ciência da Educação que organizam as práticas de educadores e educandos no tempo contemporâneo é de 
grande significância, visto que existem outras humanidades capazes de ensinar o moderno ocidente a rever sua construção em vários aspectos.

Olhe com atenção os princípios da Epistemologia Crítica representados no Esquema 7, a seguir:

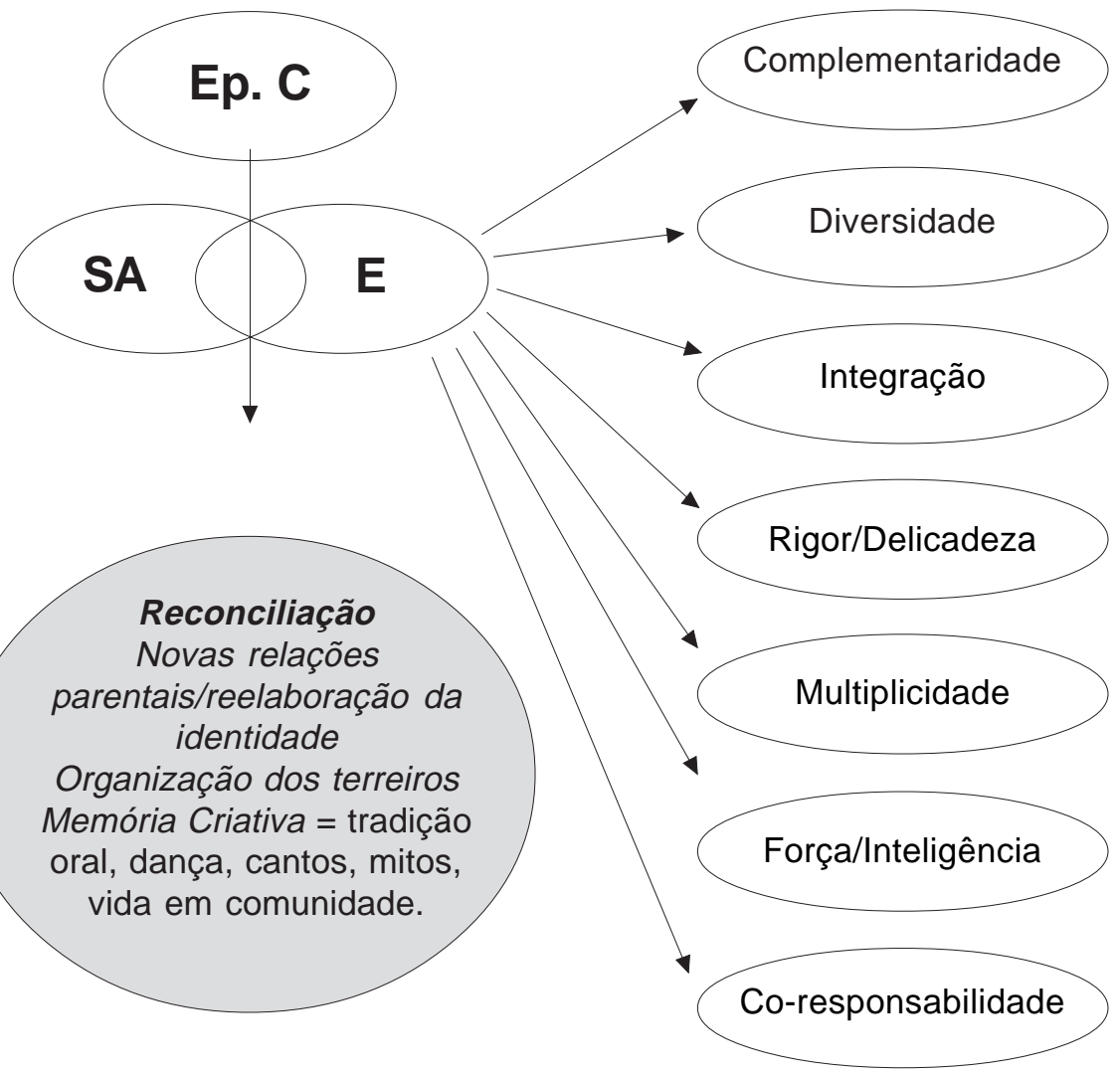

\section{ESQUEMA 7}

Fundamentos - Princípios da Epistemologia Crítica: Sujeito Afrodescendente; RECONCILIAÇÃo (FUNDAMENTO); EXPERIÊNCIA (PRINCÍPIOS, VALORES)

Para que uma Epistemologia Crítica edifique a formação do educador do Ensino Fundamental, é preciso compreender, para- 
fraseando Freire em sua linda forma de dizer o que pensa sobre o ensino em Pedagogia da Autonomia, que: ensinar Cientificamente requer possibilitar aos educandos uma forma de reconciliação permanente com a sua experiência; ensinar Cientificamente requer a consideração da diversidade e da multiplicidade da vida; ensinar Cientificamente requer incorporar à sua prática a visão de complementaridade; ensinar Cientificamente requer a valorização do rigor, mas... com delicadeza; ensinar Cientificamente requer a incorporação do sentimento de co-responsabilidade; ensinar Cientificamente requer inteligência; ensinar Cientificamente requer desenvolver o sentimento de necessidade de integração com a natureza e com os grupos humanos, mediada por uma leitura crítica da realidade.

\section{A - Ensinar Cientificamente requer possibilitar aos edu- candos uma forma de reconciliação permanente com a sua experiência}

$\mathrm{Na}$ escola de ensino fundamental, faz-se importante que seja realizada a seguinte tarefa: possibilitar que o sujeito se reconcilie permanentemente com a sua experiência. Isso não significa dizer que ele não irá reconstruir ou requalificar essa experiência a partir do diálogo, que deverá ocorrer. É importante não negar a ele essa condição de vincular-se cotidianamente com a experiência vivida fora dos muros escolares. Quando essa experiência é negada, produzse o ser abstrato, pura razão, já tão historicamente valorizado. Propor atividades nas quais a criança afrodescendente possa revelar sem medo, dialogar, não silenciar essa experiência deve fazer parte da prática contemporânea do educador no Estado da Bahia. Esperamos que essa prática seja capaz de dar vez e voz aos mitos africanos, nas "rodas de debates" e na seleção dos livros de literatura, para que possam ser livremente interpretados e contemplados. Esperamos também que ela possa permitir que o sujeito use os seus objetos definidores de uma identidade que lhe é peculiar, como por exemplo o contra-egum, permitindo a conversa livre sobre seus significados. 
Quando consideramos esse método, pautado na diferença e na valorização da experiência, não excluímos um trabalho "formalmente" reconhecido pelo contexto escolar: o trabalho com os conteúdos formais e universais. É possível considerar essa experiência no estudo da Língua Portuguesa: mitos e músicas podem ser escritos, analisados, reescritos e até, quem sabe, traduzidos para outras línguas - Yorubá e Banto - que exercem fortes influências na construção da identidade baiana. Além disso, os problemas cotidianos vividos por esses sujeitos, podem ser interpretados matematicamente, visto que a vida nos terreiros exige criação de estratégias numéricas, configurando-se como uma habilidade e competência universal do ser humano (o raciocínio lógico/matemático). A Matemática também está presente nos espaços sagrados, apesar de, em nenhum momento, a isto se fazer referência, como observado no cotidiano escolar. É possível, ainda, incluir e ampliar a compreensão geográfica a partir da organização territorial e política dos terreiros de Candomblé, sua história, sua gente. É possível considerar a experiência do sujeito de várias formas e, para isso, é importante compreender que método não deve ser um conjunto de regras mecânicas, certas e permanentes, como alertam Morin, Ciurana e Motta (2003). Afinal, a realidade é dinâmica e requer do educador a capacidade de reinventar e criar cotidianamente a sua prática. Método pode permitir a expressão individual e, deste modo, pode ser considerado como caminho, ensaio gradativo para e do pensamento. Pode ser também atividade do sujeito pensante, vivente, não abstrato, capaz de (re)inventar e (re)aprender durante o seu caminhar.

\section{B - Ensinar Cientificamente requer a consideração da diversidade e da multiplicidade da vida}

Os princípios da diversidade e da multiplicidade são fatos de vida. Entretanto ainda não são reconhecidos em nosso contexto social. Aprender esses princípios afrodescendentes colocaria a escola e a formação docente na condição de abertura para a diferença, já 
que os sujeitos que aí se situam carregam essas características, independentemente de serem ou não explicitadas e consideradas.

O ensino linear, ainda presente no cotidiano escolar, não contempla a diversidade e multiplicidade, seja no sentido das identidades dos sujeitos, seja no sentido dos fatos políticos, econômicos e sociais. Torna-se, portanto, excludente e autoritário, já que tenta homogeneizar a diferença.

É preciso que a metodologia do educador incorpore aos seus fundamentos esses princípios. A diversidade de ordem cultural, social ou econômica expõe as necessidades de valorizar a criança afrodescendente, indígena, cigana, suburbana, a que trabalha e de buscar, no processo e junto com elas, as metodologias que as contemplem. Decerto, o educador se perguntará: Como fazer? Como considerar essa diversidade, já que ao longo de nossa profissão aprendemos, ao contrário, a trabalhar didaticamente, tomando a homogeneidade, a linearidade como fundamento, abstraindo esses sujeitos do contexto de sua experiência? Nesse sentido, uma atitude pode ser inicialmente pensada: a atitude dialógica, já tão defendida por Freire e pouco percebida no cotidiano escolar. O diálogo abre as portas para pensarmos os caminhos possíveis, e é preciso estar disponível para dialogar e para escutar sensivelmente esses sujeitos.

Estar disponível ao diálogo e à escuta, com aqueles e aquelas que podem se apresentar diferentes de nós e das ideologias dominantes, é estar aberto à diversidade e à multiplicidade que a atividade docente carrega. Freire (1996, p. 136) considera que "O sujeito que se abre ao mundo e aos outros inaugura com seu gesto a relação dialógica que se confirma como inquietação e curiosidade, como inconclusão em permanente movimento na História." O educador que contempla a diversidade e a multiplicidade da vida abre-se ao diálogo profundo com os seus educandos e educandas e passa a inaugurar um movimento contrário àquele que produz o "educando abstrato", sem alma, apartado da experiência. 


\section{C - Ensinar Cientifica mente requer incorporar à prática a visão de complementaridade}

Ensinar é uma relação entre sujeitos e, por isso, não deve ser pensada a partir de um ponto: o professor. O ensino requer a compreensão de que só se efetiva quando aquele que aprende participa do ato. Ensinar é, portanto, uma ação de complementaridade entre aquele que ensina e aquele que aprende. Nesse processo, cada um dos sujeitos que participa da relação compartilha seus saberes, suas experiências. A partir daí novos saberes, conhecimentos e experiências são produzidos, além de resignificados os já existentes.

Verdades absolutas são prejudiciais nessa relação, visto que compartilhar o que cada um possui requer despir-se de autoridades pré-definidas e abrir-se à doação daquilo que se possui de significativo e que colaborará com o crescimento do outro. Compartilhar conhecimentos e experiências possibilita uma "virada" na relação pedagógica, já que a autoridade do educador é transformada em capacidade de doação e acolhimento de sentidos úteis ao processo educativo.

A Pedagogia moderna, em seus fundamentos, foi incapaz de perceber que a humanização, ou educação, dos sujeitos só se efetiva quando não há hierarquias e quando educador e educandos se percebem enquanto sujeitos que se complementam e trocam histórias e saberes, com vistas à produção de conhecimento que tenha, de fato, sentido e significado para ambos.

\section{D - Ensinar Cientifica mente requer a valorização do rigor, mas... com delica deza}

A Ciência da Educação Moderna perseguiu o rigor metodológico, buscou os métodos mais eficazes, as técnicas mais seguras para possibilitar a produção de conhecimento do educando. Caminhos importantes, mas não percorridos comumente no interior das escolas. A preocupação com o rigor (fazer de forma certa, usar 
o método certo e eficaz) foi responsável pela elaboração de uma Pedagogia, na maioria das vezes desumana, já que traduziu o rigor como a necessidade de ser imparcial. Para isso, universalizou os sujeitos e os métodos, a fim de atingir a todos de maneira igual. Ser rigoroso implicou na capacidade do educador de elaborar técnicas e métodos que atingissem, de maneira certa e segura, a quantidade de conhecimento produzido pela totalidade de sua "classe", resultando, mais tarde, na capacidade docente de traduzir esse conhecimento quantitativo em uma nota. Esta se traduziria em característica pessoal dos educandos: aluno nota 10 é excelente; tal aluno é bem fraquinho...

O rigor metodológico é importante na formação docente, mas é preciso qualificá-lo a partir de uma outra perspectiva. É possível ser rigoroso, mas com delicadeza, tal qual o Orixá Oxumaré ${ }^{12}$. O rigor não anula a possibilidade da doçura. Perceber que um método nem sempre será seguro e que ele pode ser construído junto com os educandos é atitude necessária. Ser rigoroso, neste sentido, implica estar comprometido com uma educação de qualidade, que ajude os educandos a tratar sem superficialidades as questões problemáticas que se apresentam no cotidiano da escola e da vida. Buscar aprofundamento de análise e compreensão, refletir criteriosamente, indo à "raiz" das questões investigadas, são características de uma Pedagogia rigorosa, que não deve, entretanto, violentar a condição de humanidade dos educandos e dos educadores. É preciso que o educador apresente rigor metodológico, mas que incorpore a isso a capacidade de dialogar delicadamente com seus educandos, tendo em vista uma educação mais justa, menos universal, menos classificatória e desumana.

\section{E - Ensinar Cientificamente requer a incorporação do sentimento de co-responsabilidade}

Nana e Oxalá são co-responsáveis pela criação. Educador e educandos devem ser co-responsáveis pelo processo educativo e pela criação/produção do conhecimento na escola. Esta afirmação 
atesta o fato de que o conhecimento não ocorre sem a participação responsável do outro. Educador e educandos têm as suas parcelas de responsabilidade no processo, pois o educando não produz conhecimento sozinho. A participação ativa e interessada do educador nesse processo é de fundamental importância, visto que ele deve colaborar com a permanente (re)significação do saber em conhecimento.

Desenvolver o senso de co-responsabilidade é perceber-se como sujeito histórico que, exatamente por ser histórico, não se constrói sozinho. A co-responsabilidade dos seres históricos no processo de produção de conhecimento possibilita a ampliação do compromisso da Pedagogia com a vida dos educandos. Se o educando produz conhecimento significativo ou não, o educador deve saber identificar a sua parcela de responsabilidade e junto com ele buscar (re)criar os caminhos. O educando precisa ser autor do seu próprio caminho de aprendizagem, mas, nesse processo, ele precisará do apoio e do "acompanhar dialógico" do educador.

O conhecimento se dá em comunhão. Ele é resultado de um co-pertencimento e implicação, tanto do educando quanto do educador, no processo educativo.

\section{F - Ensinar Cientifica mente requer inteligência}

Abre-se mão, neste texto, dos conceitos de inteligência puramente ligados às idéias psicologizantes e biológicas. Inteligência pode significar a relação dialética entre pensamento e ação, e ainda agir/pensar articuladamente sobre e com a realidade no seu dinamismo.

O educador "inteligente" realiza, ele próprio, e possibilita aos educandos o desenvolvimento da capacidade de problematizar e refletir crítica e politicamente a realidade. A inteligência esvaziada de natureza crítico/política só contribui com a manutenção das desigualdades e injustiças presentificadas em nosso cotidiano. 
Inteligência não deve ser pensada apenas como competência lógico/ formal e matemática, mas incorpora a competência de percepção e análise crítica e política da realidade, bem como é capaz de criar as estratégias para a superação dos obstáculos que a vida apresenta.

Nesse sentido, a coragem, o enfrentamento, a perspicácia, próprios dos filhos de Xangô, colaboram com a significação dessa inteligência; afinal, enfrentar os problemas cotidianos e tentar resolvê-los requer uma inteligência apaixonadamente crítica e política. Essa inteligência não é convencional em nosso cotidiano e, na verdade, é pouco desenvolvida nos espaços escolares.

\section{G - Ensinar Cientificamente requer desenvolver o sentimento de necessidade de integração com a natureza e com os grupos humanos, mediada por uma leitura crítica da realidade}

O moderno ocidente e sua ciência contribuíram com a construção de um pensamento de superioridade do ser humano sobre a natureza. A partir daí, as conseqüências são bem conhecidas: o super-consumo produtor de desmatamentos, poluições, extinções de animais etc., que violentam a natureza. Retira-se dela e a ela nada se devolve, muito menos se compreende seu sentido.

A Pedagogia moderna não foi capaz de discutir profundamente esta questão com os seus educandos, nem de desenvolver neles o sentimento de integração à natureza e de que o ser humano é mais uma parte dela. Este sentimento deverá ser desenvolvido mediante uma leitura crítica da realidade, pois a vida humana é dependente da natureza.

Se o ocidente tivesse sido capaz de dialogar com culturas, como a indígena e a afrodescendente, por exemplo, que ele próprio considerou historicamente primitivas, míticas, hoje, decerto, estaria estabelecendo uma outra relação com a natureza. A Ekédi Josenilda, ao discutir as relações de integração dos afrodescendentes com a natureza, nos ensina: 
Quem é de Axé ${ }^{13}[. .$.$] não deve tirar uma folha sem antes pedir a$ permissão a Ossanyin [guardador das matas] e a própria natureza. Pede-se licença a esse Orixá porque ele toma conta da natureza e nos ensina a respeitá-la. A natureza é coisa que devemos preservar. Tudo o que a gente tira deve levar de volta. Se a gente tira folhas e prepara um banho, as folhas machucadas vão ser colocadas no matinho que se integra à terra, adubando-a. As que não vão pro mato você faz incenso que também volta pra natureza, pro ar e se reintegra a ela novamente. As comidas (feijão, inhame, os animais...) que compõem o ritual são dedicados aos Orixás, mas a maioria alimenta as próprias pessoas da comunidade que participam do ritual. O corpo também deve ser alimentado [...] Então, tudo o que tiramos, devolvemos pra natureza de alguma forma. Então, tem todo um ritual também com relação ao respeito pela natureza. Agora, quem não leva a religião à sério faz diferente.

Esses princípios, que deveriam compor o ensino contemporâneo, se inspiram numa cultura historicamente discriminada pelos fatores já conhecidos. Ela nos ensina a ver o mundo a partir de uma outra possibilidade, diferente daquela construída pelo pensamento ocidental.

$\mathrm{Na}$ prática pedagógica, muito mais que ensinar história e cultura afro-brasileira - Lei 10.639, de 09 de janeiro de 2003 (BRASIL, 2004) - com aquele mesmo olhar matematizante, centrado na cognição e na reprodução, o educador deve compreender alguns princípios que edificam as produções afrodescendentes (e que hoje muitos de nós, baianos, assumimos como herança e manifestação de vida) e incorporá-los em sua conduta cotidiana e em sua didática.

Todos esses princípios devem ser assumidos como possibilidade, não como verdade a ser instituída no plano educacional. Cabe aos educadores, portanto, a abertura necessária para gerar a capacidade de reconhecimento de construções de humanidade (e de Ciência) diferentes daquelas já pensadas e que não conseguiram possibilitar ao ser humano uma existência para além do tempo linear e progressivo da razão ocidental. 


\subsection{BARREIRAS PARA A CONCRETIZAÇÃO DE UMA EPISTEMOLOGIA CRÍTICA NO ENSINO FUNDA- MENTAL}

No atual contexto, existem barreiras que impedem a concretização de uma epistemologia crítica no ensino fundamental. Estas, para serem vencidas, precisam de muito compromisso e vontade não apenas pedagógica, mas política de forma ampla. A barreira considerada mais presente é a que aponta a maneira como os educadores, e as próprias crianças, se percebem e percebem o outro na dimensão de produção da existência enquanto seres humanos. Na escola, um e outro não conseguem vincular experiência e razão, corpo e mente. Em favor do discurso abstrato (implícita e explicitamente percebido nas ações), não conseguem valorizar e validar na relação pedagógica a vinculação do sujeito com a sua experiência, tendo como facilitador o olhar distraído dos educadores frente à realidade.

As dificuldades relatadas pela comunidade escolar foram sistematizadas sob a forma de barreiras, conforme apresentado a seguir.

a) A separação sujeito/objeto, como fundamento da Ciência da Educação, gera o corte da criança afrodescendente com a sua experiência, bem como o olhar distraído dos educadores sobre a realidade

A epistemologia do educador, na atual conjuntura baiana, não contempla a experiência da criança afrodescendente. Neste sentido, o fundamento cartesiano apresentado neste estudo encontra-se validado. Destaca-se conversa em uma das escolas, onde esta situação é percebida com mais clareza. João Roque e sua mãe (ambos filhos de santo de um terreiro no próprio bairro em que moram), afirmam categoricamente o fato de a escola não contemplar a experiência dos afrodescendentes, bem como, de certa forma, fortalecer o 
silenciamento, o preconceito e a negação dessa cultura, fazendo com que essas crianças produzam conhecimento abstrato, distanciado das questões efetivamente vitais:

Ana Katia: Bom, então João, en queria que você falasse um pouco pra gente da sua experiência. Você disse que participa de uma casa de Candomblé aqui mesmo em seu bairro. Eu queria saber como é a sua vida lá. Sua família participa?

João: Participa. Minha mãe, meu pai...

Ana Katia: Eles são o que lá?

João: São filhos de santo. Minha avó e minba madrinha...

Ana Katia: E vocie?

João: Eu também sou filho.

Ana Katia: Qual é o orixá?

João: Ogum e Oxossi.

Ana Katia: Desde que idade?

João: Desde os sete anos.

Ana Katia: Hoje você tem quantos anos?

João: $D e そ !$

Ana Katia: Você tem três anos que participa ativamente e assim..., aqui na escola, naquela roda que nós fizemos com os seus colegas, você lembra que alguns meninos disseram que não queriam falar sobre o Candomblé, sobre macumba como eles falaram. O que você pensa disso?

João: Eu acho que primeiro o nome não é macumba, é Candomblé. E eles não querem falar sobre isso.

Ana Katia: E você acha o que sobre ofato de eles não quererem falar sobre esse assunto? 
João: Eles acham que alguma coisa de espirito maligno, coisa do mal. Só que na igreja universal eles ficam falando que é coisa do mal.

Ana Katia: Sei... Mas você sabe que não é isso, claro. Você está dižendo que não é! E o que é então? Como é a vida lá neste espaço?

João: Lá é bom!

Ana Katia: Por quê?

João: Lá não faz muito barulho e os outros faz̨em!

Ana Katia: Outros o quê?

João: Outros lugares!

Ana Katia: Então vocês respeitam o silêncio... O que mais?

João: Lá tem cantos, tem música pra nossa vida.

Ana Katia: Ah, e você gosta disso!

João: Muito! Tem o canto para os Erês!

Ana Katia: Hum! São alegres, divertidos, não é? O que mais é bom lá?

João: O bom lá também é que lá eles matam os bichos, fazem comida pra gente comer junto. Todo mundo junto. Eu só não gosto do sangue.

Ana Katia: E matam os bichos pra quê?

João: Pra rezar, comemorar alguma coisa junto.

Ana Katia: Como é a relação entre as pessoas lá? O relacionamento...?

João: A relação é que às vez̧es brigam. Do lado de fora da casa elas brigam.

Ana Katia: Do lado de fora? E quando elas estão lá na casa?

João: Não tem nada. Elas respeitam!

Ana Katia: E porque você acha que lá na casa se respeitam mais e fora não? 
João: Porque lá se uma pessoa briga, outra vai lá e diz que não está certo. Uma conversa com a outra e ajuda.

Ana Katia: Agora, voltando aqui para a escola, João, você pratica o Candomblé. Você diz que lá é bom por causa dessas coisas que você está falando. O silêncio, o respeito, a ajuda entre as pessoas, a música... E aqui na escola, em que momento vocês conversam sobre isso? Vocês conversam sobre essas coisas que vocês vivem no terreiro?

João: Não!!

Ana Katia: Hum... Nunca?

João: Nunca!!

Ana Katia: Nunca, nunca, nenbuma vez?

João: Nunca!!

Ana Katia: Por que você acha que isso acontece? Por que na escola não se conversa sobre a vida de vocês lá fora?

João: Acho que não tem tempo!

Ana Katia: Você acha que é a falta de tempo?

João: É.. e também o preconceito.

Ana Katia: Ah. Preconceito e falta de tempo. E o preconceito é como? Em que sentido você vê preconceito?

João: Me chamam de macumbeiro, filho do diabo...

Ana Katia: Filho do Diabo? Já te chamaram assim aqui na escola? João: Foi!

Ana Katia: E quando te chamaram assim, o que você sentiu?

João: Nada. Eu deixo pra lá. Entrego ao santo.

Ana Katia: Entrega ao santo e deixa pra lá. Como é que você entrega ao santo? Fala o que pra ele? 
João: Pra me dar paz!

Ana Katia: Sim... Pra te dar tranqüilidade, paz... Você acha que a escola deveria pensar mais sobre isso, sobre sua vida no terreiro? Conversar sobre essas coisas que são importantes na vida dos alunos?

João: Devia!!

Ana Katia: Por que você acha...

- Boa tarde! [Chega a mãe de João para levá-lo para casa. Estava na hora da saída].

Ana Katia: Oi, boa tarde! Quer falar com João?

Mãe: É. Eu sou mãe dele.

Ana Katia: Ah! Que bom! Eu estava conversando com ele. Estou fazendo uma pesquisa. Tudo bem? Pode entrar. Deixa eu aproveitar para falar um pouco com você. Está com muita pressa?

Mãe: Não. Eu só vim pegar ele.

Ana Katia: Eu sou da Universidade Federal e estou fazendo uma pesquisa... são cinco minutinhos. Não tomo muito o seu tempo.

Mãe: Ah... tá bom!

Ana Katia: Como é seu nome?

Mãe: Vera.

Ana Katia: Olha, Vera, a gente está conversando sobre as relacões entre o Candomblé e a escola. Como é que a escola trata as crianças que participam dessa religião. É que a gente tem identificado muito que a escola não respeita essa experiência e as crianças que cultuam valores africanos. E ai eu estava conversando com João sobre essas coisas e ele estava acabando de direr isso mesmo, que há preconceito, que a escola não trabalha com essas coisas. Eu perguntei se a escola conversa sobre o Candomblé e ele disse firmemente que não, que nunca conversa e parece 
que quando "conversa" épara lhe chamar de macumbeiro, filho do diabo. E ele estava me passando essas coisas. E a gente vem estudando também em outras escolas e é muito parecido. Falam do preconceito, da discriminação que ainda é muito grande. E você o que acha?

Vera: Dentro da escola e fora também. Por sinal eu não uso roupas decotadas por causa do preconceito comigo. As pessoas olham e dizem logo: macumbeira!

Ana Katia: Por que não entendem o sentido, a simbologia, a cultura, o que se passa de fato...

Vera: Isso!

Ana Katia: E aí João estava me contando que a escola não conversa sobre essas questões. Eu percebo isso também, porque trabalho há mais de treze anos na escola e vejo que ela nunca conversa, porque há muito preconceito, principalmente porque diz respeito a cultura negra.

Vera: É. Que é coisa do diabo!

Ana Katia: E por isso está sempre discriminando os praticantes da religião. E ai eu queria aproveitar que você está aqui e queria que você dissesse o que pensa sobre a escola neste sentido.

Vera: Então, eu acho assim, que a escola, como lugar de orientação e ensinamento, devia fazer trabalhos... entendeu? Peças, mostrando, explicando, porque não é essa nuvem negra que as pessoas pintam, que é coisa ruim, que faz mal aos outros. Além disso, ele tem coisas muito boas que todas as pessoas podem usufruir, entendeu?

Ana Katia: E vem de uma tradição africana que é nossa, mas que a maioria das pessoas prefere negar.

Vera: É isso! Por sinal, pessoas de nivel alto, né?

Ana Katia: Você acha que isso está relacionado a quê?

Vera: É porque é religião de africano. O Candomblé vem dos escravos. 
Ana Katia: Por isso discriminam, porque tem a ver com a escravidão?

Vera: Com certeza! Por isso tem discriminação.

Ana Katia: João diz que desde os sete anos ele é do terreiro...

Vera: É, mas ele vai ser Ogan de outra casa quando ele fiz̨er trez̨e anos.

Ana Katia: Vai assumir essa responsabilidade...

Vera: É. Já que ele foi escolbido... vai passar pelo ritual...

Ana Katia: Sei... Então, João, você acha que a escola devia mudar essa postura.

João: Acho. Conversar sobre isso.

Ana Katia: É isso, Vera, a pesquisa está neste caminho de repensar a relação da escola e da formação do professor frente a essas crianças. E no futuro tentar divulgar esses resultados, esse trabalho de compreensão acerca desse tema: dos valores e princípios de tradição africana e bem presentificados nos terreiros. Tentar desconstruir essa visão negativa e que passemos a considerar como parte importante da vida dessas crianças. Como a escola consegue negar algo que se vive lá fora, na vida?

Vera: É! É uma coisa da gente, né? Quer dizer, fazparte da cultura, da raça negra. E é uma coisa que tem que ser respeitada, mas infelizmente não é.

Ana Katia: Sim...

Vera: Olhe, eu mesma estou querendo sair por causa disso mesmo. Porque...

Ana Katia: Você está querendo abandonar a religião por causa do preconceito?!

Vera: Estou! Estou querendo sair, porque é muita discriminação.

Ana Katia: Mas você não acha que existe uma forma de resistir a esse preconceito, a essa discriminação? 
Vera: Sei lá! Só a pessoa passando por isso, entendeu, pra sentir.. Porque é terrivel! E aqui onde a gente mora tem muitas pessoas religiosas e criticam muito, falam muito mal, entendeu? Volta e meia meus filhos vêm e dizem que estão falando: Ah... sua mãe é macumbeira! Não sabem respeitar. Cada religião devia respeitar a outra. Um respeitar o outro. Então, por eles, eu prefiro até me afastar, pra evitar meus filhos de certos constrangimentos. Porque eu sou adulta, entendo, mas eles que são crianças...

Ana Katia: Você não acha que é por isso que cada vez mais a gente tem um número menor de pessoas praticando o Candomblé ou negando que praticam?

Vera: É!! Sem dúvida.

Ana Katia: Uma coisa que me perguntaram na faculdade foi como é que eu ia encontrar as crianças que cultuam o Candomblé, já que parece tão difícil. Me parece que, por causa da pressão social, as pessoas começam a se afastar ou praticar a religião ocultamente, têm vergonha, se protegem dos problemas... porque o preconceito é tão forte! Mas acho que, que... conversando com João eu fiquei felize em perceber que João enfrenta com tranqüilidade e consciência, até certo ponto critica essas relações vividas na escola, sabe dos problemas que enfrenta, e na sua inocência acha até que a escola não trabalh a muito essas questões porque, além do preconceito, ela não tem tempo. Agora...

Vera: Eh... não é isso não!

Ana Katia: A gente sabe que não é bem isso, mas na cabeça dele é isso, apesar de considerar o preconceito muito forte também: chamá-lo de filho do diabo, macumbeiro... Ele viu que na semana passada fizemos uma rodinha para uma conversa com todas as crianças da turma de João para falar um pouco dessas questões e perceber o que elas pensam sobre o assunto, e João viu que algumas delas levantaram da roda dizendo que não ia falar dessa coisa de macumba, usando o nome pejorativo mesmo. Então, eu acho que a escola precisa trabalhar essas questões, para que a 
gente aprenda a respeitar o outro, incorpore a diversidade em nossas práticas. Não que se queira que todos da escola se aprofundem na religião e estabeleçam relações efetivas, mas o que épreciso é respeitar a experiência daqueles e daquelas que a praticam.

Vera: Mas tem muitos pais aqui que são católicos, que não querem saber disso não. Não vai mesmo! Tem pais que botam crianças aqui... eu falo isso porque eu vejo meu filho sofrer. Cinco anos estudando aqui e tem pais aqui que tiram a criança da escola por que a escola é São Roque e todo ano oferece um caruru aqui. Tem pai que tira por causa disso.

Ana Katia: Eh! Ainda bá muito desrespeito. Muito preconceito.

Vera: Efalam que é coisa do diabo. Que não sei o quê.... Porque todo ano acontece uma tragédia, mas eles acham que é por conta da presença da religião, de crianças e pais do Candomblé na escola. Então eu acho que a escola não tem nada a ver com a realidade. Eu acho não, eu tenho certeza! Porque ela não comenta nada sobre isso. Não fala, não fala nada de Candomblé, nunca vi um trabalho aqui, nenhum realizado em relação ao Candomblé. Eu acho que é puro preconceito.

Ana Katia: Sim... Separa coisas importantes da vida de algumas pessoas que estão aqui na escola. Quer dizer, nem se discute aquilo que as pessoas vivem efetivamente fora da escola. Geralmente "se cria" o que vai ser conversado. Não considera o cotidiano. Então, a gente está pesquisando essas coisas. Eu também tenho irmãs praticantes, a familia é de religiosidade africana forte, e eu como educadora analiso essas questões. Acho que a escola deve ser repensada neste aspecto. Estou pesquisando aqui na escola e descobri que João é uma dessas crianças que praticam o Candomblé e estávamos conversando pra eu entender melhor o que se passa, o porquê desse preconceito todo... não é João?

Vera: [risos] Eh! Eu sou adulta não estou nem aí. Entra por aqui e sai por cá! Mas ele que é uma criança vai reagir de outra forma e termina tendo confusão. 
Ana Katia: Muito obrigada, Vera. Essa nossa conversa vai ser registrada em meu projeto... Ab!... se você quiser que eu coloque um nome fictício no lugar do seu nome real... se você preferir...

Vera: Não! Eu estou falando o que é verdade pra mim!

Ana Katia: Tudo bem! Muito obrigada pela disponibilidade, viu? E boa sorte. Eu espero que você consiga repensar isso, se é uma prática realmente importante pra você.

Notamos que no ensino fundamental de nosso contexto, de fato, o corte homem/mundo, experiência/razão se valida cotidianamente. Nesse sentido, é fortalecida a formação da criança enquanto produtora de habitus, já que ela acaba se distanciando e negando a sua experiência e, em paralelo, incorpora como sua a experiência de uma outra cultura viabilizada pelo discurso docente e pelos conteúdos formais. Neste caso, ainda se vê que o discurso hegemônico, apesar das tentativas dos adultos da escola de negar conscientemente esse fortalecimento, é da cultura branco-européia e também norte-americana.

A constatação desta barreira se deu também na observação das posturas de muitos educadores relativas a um "olhar distraído" ou "desinteressado", frente à realidade das crianças e de sua comunidade. Numa das conversas informais com as crianças e os educadores, pudemos perceber, enquanto passeávamos no pátio, a existência de um terreiro de Candomblé no pé da serra, bem próximo da escola.

Perguntamos se alguém sabia que casa era aquela e o que representava. Dentre os envolvidos na conversa, apenas dois alunos souberam identificar, já que eles participavam da casa (filhos-desanto). Foi um momento significativo, visto que o professor assumiu que nunca tinha parado para prestar atenção - apesar dos objetos identificadores da casa, tais como o Mariô (pequenas cortinas feitas de palhas de dendê postas na porta e janelas) - e muito menos tinha 
informação de que seus alunos participavam daquela casa. Deste modo, fica evidente que a escola e o educador precisam reavaliar os seus comportamentos e pensamentos, no sentido de valorizarem a experiência efetiva que as crianças já possuem para além dos muros da instituição escolar.

b) A interpretação realizada pelos educadores sobre a epistemologia genética (mais conhecida entre eles como construtivismo) impulsiona o olhar linear sobre os sujeitos. O biológico é mais importante que o cultural, o social, o político...

A visão de verdade na formação docente no Ensino Fundamental é fato marcante. $O$ discurso verdadeiro, universal, presente nos discursos e práticas percebidas nesse nível de ensino não comporta a diversidade. Ele busca o que é linear, progressivo. Nesse sentido, a ciência do educador assume como eixo de verdade, para a produção de conhecimento das crianças, a epistemologia genética ou construtivismo (termo mais corrente para fazer referência à teoria piagetiana no Ensino Fundamental).

Observamos que a interpretação da epistemologia genética favorece a "verdade absoluta", no que diz respeito ao conhecimento produzido, tendo como eixo fundamental o aspecto biológico do ser humano. Se o biológico é supervalorizado, torna-se evidente que os demais aspectos passam a se tornar secundários. Daí ocorre a desvalorização dos aspectos sociais, culturais, políticos, econômicos, tão importantes como o biológico, na produção de conhecimento das crianças. Neste sentido, as questões étnicas, raciais e relacionadas às condições sociais são raramente tratadas na escola. Se a produção de conhecimento é um dado biológico, dispensa a preocupação com outras questões, já que, no discurso corrente, somos todos biologicamente iguais e, por isso, produzimos conhecimento de maneira igual. 
Em conversa com professores do ensino fundamental, fizemos duas perguntas, com a intenção de perceber como eles vêm interpretando a epistemologia que assumem ao organizar o processo de ensino/aprendizagem. A primeira foi a seguinte: "O que vocês entendem por epistemologia genética?" Ouvimos como resposta:

Discute a gênese do conhecimento e dĩ que é uma construcão psicológica. É conhecimento armazenado possibilitado pela genética do indivíduo.

Estuda o comportamento a partir da hereditariedade, do biológico.

Caracteres genéticos que influenciam o desenvolvimento.

Estuda a origem, a natureza e os limites do conhecimento.

Carga genética de cada indivíduo que irá se desenvolver em capacidades cognitivas.

À segunda pergunta, "A partir de sua interpretação sobre epistemologia genética, que aspecto é mais trabalhado na criança, a fim de possibilitar o seu desenvolvimento?", os professores responderam:

A formação biológica, psicológica emocional do educando.

A cognição.

O emocional, o afetivo, o intelectual e o orgânico.

Raciocínio lógico e crítico.

Reflexos e estímulos.

As fases do desenvolvimento biológico, orgânico.

Essas falas revelam a extrema preocupação com o aspecto biológico. Dificilmente há preocupação, na produção de conhecimento, com os demais aspectos que participam dessa construção. Assim, essa interpretação não comporta a diversidade e, já que somos 
todos biologicamente iguais, é possível assumir a cultura branca como eixo de formação de todos, inclusive do sujeito culturalmente diferente dela. É evidente que a existência desse fato foi percebida nas entrelinhas, na face oculta do cotidiano escolar. Parece que somos "incapazes" de considerar a diversidade na formação humana e, conseqüentemente, na produção do conhecimento, em nossas interpretações docentes.

c) A intolerância religiosa, conseqüência do preconceito contra as crianças afrodescendentes na escola

Essa terceira barreira considera, principalmente, falas de educadores (e alguns pais de alunos) frente à postura das famílias com relação à intolerância religiosa. Apesar de ser um problema presente na sociedade como um todo, na escola se apresenta com mais força. As exigências que muitas famílias fazem, principalmente no que diz respeito à negação e perseguição que deve ser validada em relação ao Candomblé, instaura um clima de rivalidade e desrespeito pelas opções religiosas do outro (sejam crianças ou pais).

Essa intolerância é carregada de discriminação e preconceito, primeiro por ser uma prática da cultura negra/escrava, depois por ser uma religião que, segundo elas, se afasta do divino em prol das práticas demoníacas. Algumas escolas, no contexto baiano, se preocupam com essa questão, principalmente porque, na maioria das vezes, se torna impossível dialogar com esses pais (e algumas crianças que também discriminam), visto que os mesmos se negam a estabelecer qualquer relação com praticantes de religião diferente da sua. Às vezes, de forma violenta, os ofendem verbalmente e ameaçam tirar os filhos da escola se ela "der voz" à religiosidade da cultura afro-baiana.

A intolerância religiosa, segundo Oliveira (2003), está muito presente em nosso cotidiano, apesar de muita gente tentar negar 
que ela existe ou que esse é um problema do Oriente Médio, da Irlanda ou da Europa Oriental. Ao contrário, esse fato avança aberta e grosseiramente muito próximo a nós. Parece-nos que um retorno às antigas práticas religiosas medievais se faz presente em nosso cotidiano, no sentido da negação e "acusação" ("cremam na fogueira verbal") daqueles que praticam o Candomblé. Mais uma vez, o respeito à diversidade é inexistente no cotidiano escolar, tanto na postura das famílias como de muitos educadores, e ainda em alguns discursos das crianças, que reconhecem seu preconceito em relação a esta prática de origem africana:

Eu tenho que assumir que eu ainda sou muito preconceituosa, eu sou demais... principalmente com relação à religião, o Candomblé. Eu vejo o Candomblé como uma coisa negativa, sabe? Talvez pelo conhecimento negativo que eu tive durante todo esse tempo, porque eu não conbeço profundamente, não sei bem como é que acontece, então eu só sei que o que me faz ver o Candomblé como uma coisa negativa é a questão de fazer o mal. Então, fazer o mal pra mim não presta. (Educadora).

Com relação à postura intolerante presente no comportamento das próprias crianças, ressaltamos um momento vivido numa escola de bairro popular da cidade de Salvador. A fim de perceber como as crianças vêm lidando com a diversidade na escola, propusemos uma atividade que seria iniciada após o relato de um mito africano, sua origem, presença na cultura baiana e contexto religioso. Logo no início, algumas crianças se retiraram da roda, dizendo que não estavam na escola para falar de "macumba"14.

A fala de Jéssica Santos (09 anos, iniciada no Ilê Axé Oxumarê) reafirma esse fato:

Não se toca no assunto de Candomblé. Eu já tentei falar com minhas amigas da escola, mas elas dizem que é coisa do diabo. Ai eu não conto nada. Fico calada [...] Às vezes a professora fala da África, mas não toca no Candomblé, e fala de outras religiões também. 
A intolerância religiosa, articulada com a discriminação e o preconceito social frente à cultura africana, é dado significativo e que dificulta a constituição de uma epistemologia crítica. Por isso mesmo, pôr em debate freqüente essa questão é a uma das tarefas do educador que deseja repensar os fundamentos de sua ciência.

No que diz respeito à intolerância religiosa frente à criança afrodescendente, percebemos a necessidade de assegurar um direito legalmente reconhecido e sujeito a punições pelo infrator (art. 16, da Lei 8.069, de 1990, já citado neste trabalho e insistentemente relembrado): "[...] a criança tem direito de liberdade nos aspectos de opinião e expressão, crença e culto religioso, participar da vida familiar e comunitária sem discriminação.” (DARLAN, 1998, p.21). É importante considerar, no entanto, que um artigo de lei por si só não garante esse direito na prática. É preciso que os sujeitos envolvidos (crianças, pais, educadores...) alcancem uma qualidade de formação humanitária que prime por considerar o outro na sua diferença. A escola, nesse sentido, assume uma responsabilidade fundamental frente a esse processo de formação. A diferença é um fato de vida e precisa ser compreendida e considerada nas práticas escolares.

d) A atual configuração da escola é perversa e dificulta a formação de uma Epistemologia Crítica, principalmente quando se considera o método, a Didática, a partir das condições de formação possibilitadas aos educadores

Essa barreira foi apontada como sendo também de fundamental importância no sentido de buscar saídas, visto que a escola, da forma como está organizada hoje e como pensa o sujeito, só colabora com o fortalecimento de uma ciência da educação excludente, que nivela os sujeitos por níveis de conhecimento e fortalece o distanciamento da criança afrodescendente da sua experiência concreta. 
Nas falas dos educadores, a questão referente às dificuldades com o método, com a didática é bem marcada:

Educador X: Inclusive, quando a gente tava fazendo, no ano passado, aquele projeto Escola Plural, eu, Glória... que era a escola plural, "A Diversidade está na Sala de Aula" [...] a gente discutia que essa diversidade está na sala e discutimos muito nesse sentido, que a visão é sempre eurocêntrica, ou a todo o momento, nós educadores, estamos sempre procurando "fechar" as questões, nunca pode deixar em aberto. Vai discutir sobre universo, ai a gente acha, então como o livro traz, ou como eu acho, sempre chega na resposta "verdadeira" que conclui. Nunca a gente ousa deixar em aberto aquela questão que pode ter sido assim, on assim... então, se pega nessa questão de como a gente é preconceituoso nesses aspectos e também em outros minimos, que passam batido, às vezes em dividir a sala desta ou daquela maneira, por gênero, ou por conbecimento, tudo isso a gente vai...

Educador Y: nivelando, separando...

Educador X: É! E a forma que a gente, eh... passa, a visão que a gente passa, porque às vezes passa só por uma questão didática, mas pra criança pode ter outra conotação: lá estão só os que sabem matemática, ou só os que não sabem. Lá estão só as meninas [...] Então a gente tem que "se policiar" e saber o quanto isso é difícil e que está tão arraigado na nossa construção escolar e no profissional também, que quer fazer também dessa forma... então é uma questão muito interessante.

Outra educadora também considera que as dificuldades com o método são pontuais. Afirma que já fez diversos cursos, inclusive com grupos conhecidos que defendem a cultura africana na Bahia, mas a questão de fundo, segundo ela, nunca foi tocada. A metodologia do educador precisa de atenção, já que o que se discute fica num plano muito teórico. Em sua fala, deixa claro que esses cursos "ditam" apenas que a escola tem que fazer certas coisas e culpa o educador, por não saber fazer. Entretanto os educadores dificilmente enunciam os fundamentos e concepções do método. 
Sendo assim, a Pedagogia enquanto ciência precisa mesmo ser re-pensada. Esse "descuido" quanto ao método também se apresenta na postura dos formadores desses educadores. Nos cursos de graduação em Pedagogia, principalmente nas disciplinas Didática, História e Filosofia da Educação, poucos fundamentos são de fato apresentados e discutidos com rigor. Se tomarmos, por exemplo, a disciplina História da Educação, nos livros didáticos e na discussão proposta nas ementas dos cursos, percebemos a ausência da cultura do afrodescendente, do mesmo modo que nas disciplinas Filosofia da Educação e Didática. É opaco o discurso e o aprofundamento acerca dos fundamentos da Ciência e, conseqüentemente, da Ciência da Educação. Essa formação acaba afetando de várias maneiras a visão dos educadores frente ao ensino, bem como colabora com o fortalecimento de uma escola organizada para a exclusão e para a negação da diversidade. Ao priorizar determinados conteúdos, essa escola vem assumindo uma prática desfavorável à experiência da criança afrodescendente, visto que está muito mais concentrada em ensinar "Língua Portuguesa e Matemática", em detrimento de estudos culturais, políticos etc.

Numa reunião de educadores, em que se discutiu o PDE (Plano de Desenvolvimento da Escola), esse problema foi levantado:

Educador W: Mas, voltando viu? O PDE privilegia a Lingua Portuguesa e a Matemática. Mas, o que a gente vê na sala de aula é a mesma coisa. E o que a Escola em Desenvolvimento detectou foi a mesma coisa. A gente vai pra sala e o professor está lá trabalhando exclusivamente Lingua Portuguesa e Matemática. 80\% Lingua Portuguesa e 20\% matemática. E eu acho que vou sentar e fazer uma estatística mesmo, por hora, pra poder dar esse dado assim... Então não é um problema do PDE. Em compensação, a gente ainda vê os meninos sem conseguir ler, a gente não tá faz̧endo diferente [...]

Educador Z: Mas a carga horária de Lingua Portuguesa também é maior. 
Educador W: A carga horária é maior, mas na sala de aula é? Não é nem maior, nem menor! Só é! É uma coisa pra gente pensar. Quando a gente fezo PDE, foi um problema que a gente também detectou. E aí, alguns professores disseram que não sabiam trabalhar de uma forma, interdisciplinarmente, de uma outra maneira. E nós tentamos colocar aqui, no PDE, uma capacitação, mas não pudemos colocar... tinha que ser dentro disso ai: Lingua Portuguesa e Matemática. Apesar de a gente ter tomado isso aí como uma crítica ao PDE, nós estamos realmente fazendo a mesma coisa. E quando a gente vai em alguma sala dos professores, fazer um acompanhamento, eu vi a aula e não tinha as outras áreas. Então não é... eu na verdade não estou dizendo nada, eu só quero que a gente reflita, veja realmente em que nivel. Se a gente está pensando nisso, porque é que a gente não está fazendo? Então, vê se pelo menos Lingua Portuguesa, que é 80\% mais, surte algum efeito.

Ana Katia: Eu queria falar algo.

Educador W: Claro!

Ana Katia: No processo de pesquisa em Camaçari e Candeias, a gente chegou à mesma conclusão. Aqui também, em Salvador. Na verdade, é uma construção, infelizmente, ainda muito forte no Ensino Fundamental, não é? Ensino Fundamental e Médio também. A gente tem uma compreensão de que o trabalho tem que ser mais conceitual no sentido da matemática, da Lingua Portuguesa, das coisas mais abstratas. Claro que a Lingua Portuguesa é instrumento fundamental para a construção do sujeito enquanto falante da língua. Então, quando você conhece a sua lingua, você se conhece enquanto sujeito. Mas a gente sempre teorizou mais esses aspectos em detrimento de outros que são tão importantes quanto. Então eu acho que o que você está falando é algo sério, muito pontual, significativo mesmo. E o interessante é quando você fala que é para a gente refletir, porque é algo que não acontece apenas aqui nesta escola. É algo que está hoje na prática pedagógica de maneira geral e tem a ver com a formação de professores, nesta visão política de educação, na carga horária instituida. 
Também a forma como a escola vem considerando a participação dos pais parece-nos muito equivocada. Trazer os pais para a escola não significa ficar "refém" deles, principalmente no sentido que já discutimos no tópico "barreira sobre a intolerância". A escola não está conseguindo estabelecer um diálogo saudável com as famílias e isso acarreta problemas que afetam diretamente a formação dos sujeitos que vivenciam este espaço. Construir novas bases para o diálogo entre família e escola parece ser imprescindível no contexto atual.

Tem-se ainda, nesta reflexão sobre a organização escolar, a necessidade de atentar para o discurso veiculado a partir dos conteúdos selecionados no currículo. Verificar a natureza e o teor político de cada um deles também é uma tarefa que cabe aos educadores, enquanto coletividade, já que precisam analisar o que de fato deve servir como fundamento do ensino no sentido teórico. A sistematização desses conteúdos, na sala de aula, participa diretamente da produção de conhecimento das crianças. Se esse discurso ou conteúdo vem carregado de poder ideológico, discriminatório, as conseqüências já são conhecidas: manutenção do status quo, império de uma cultura sobre outras, negação de identidades.

Essas barreiras aqui descritas, percebidas no cotidiano escolar do Ensino Fundamental, devem se configurar enquanto caminho de profunda reflexão para um repensar da epistemologia do educador que vem organizando a produção de conhecimento da criança afrodescendente. 



\section{$\operatorname{cosithth}\left(\frac{3}{3}\right.$}

\section{HISTÓRLA E CIENTIFICIDADE DO ENSINO FUNDAMENTAL BAIANO: HA LUGAR PARA A DIFERENCSA NA ESCOLA QUE FAZEMOS?}

Obra da Modernidade, avessa à "singularidade carnal do sujeito", a escola que conhecemos é um sistema racional idealizado pelo pastor tcheco Comênio no século XV II [...] em sua Didática Magna-obra que é considerada fundadora da Pedagogia (ou 'Ciência da Educaşão') - só há lugar para as ações educativas conscientes e metódicas [...]

Bacha (2004, p.2)

\section{$\Gamma$}

or que a escola sente calafrio e repulsa pelas singularidades carnais, pela experiência mundana dos sujeitos? Esta inquietação possibilita uma incursão na história do Ensino Fundamental na Bahia, visto que, em seu processo de construção e validação pela sociedade, revelou-se como espaço de negação, de representação e silenciamento das experiências culturais produzidas pelos educandos no mundo "extra muros" escolar, principalmente das crianças afrodescendentes na sua diferença. $\mathrm{Na}$ Bahia, de população predominantemente afrodescendente, negra, é difícil compreender que, na escola, ela produz conhecimento distanciado de sua experiência, principalmente a experiência cultural produzida no interior das comunidades de tradição africana.

Para que essa compreensão crítica seja possível, a escola baiana de Ensino Fundamental será aqui analisada a partir de sua origem. Teve como fundamentos pedagógicos, inicialmente (séc. XVI e 
XVII), os princípios organizadores da Igreja Católica - a escola de ler e escrever - como espaço institucionalizado. Fundada na cidade de Salvador, teve os jesuítas como pedagogos, apoiados pelo primeiro governador-geral Tomé de Souza. Segundo Aranha (1996), este é o início do processo de fundação de escolas elementares, missões, seminários e também escolas secundárias. A primeira escola do Estado da Bahia, fundada em 1555, teve como principal pedagogo o padre José de Anchieta.

Como colônia, o Brasil estava organizado por uma economia que girava em torno da produção no engenho de açúcar (modelo agrário/exportador dependente e servil da Europa). Os proprietários de engenho usavam o trabalho escravo dos índios e negros africanos para a geração de altos lucros na produção. Dessa forma, a base da sociedade brasileira fundou-se na escravatura, no latifúndio e na monocultura. Nessa organização de sociedade, a Educação não era prioridade. Não era preciso formação especial para o trabalho na agricultura. Mesmo com essa compreensão, foram enviados padres jesuítas com a função de realizarem trabalho pedagógico e missionário, a fim de converter principalmente os índios, como também cuidar para que os colonos portugueses não se desviassem da fé católica. Os jesuítas também deveriam se preocupar com a formação da elite intelectual.

Nestes dois primeiros séculos (XVI e XVII), o processo educativo se fundou nos princípios católicos sistematizados no Ratio Studiorum, primeiro currículo escolar no Brasil, no qual se revelam a moral e a religião cristã, que se alia também a algumas idéias modernas ${ }^{15}$, no que diz respeito ao processo de reorganização disciplinar da escola e de racionalização e controle do ensino. Nesse currículo, é evidente que a incorporação dos saberes dos grupos locais estava fora de qualquer possibilidade. A escola baiana (brasileira em sentido geral) já se fundava a partir de um processo perverso e excludente, visto que educava violentando a cultura do outro. Aos índios e colonos (incluindo mais tarde os negros africanos) são 
impostos os valores europeus, portanto brancos, de visão adultocêntrica e machista, via religião cristã, conseguindo desintegrar ou enfraquecer culturalmente os grupos nativos e, posteriormente, a cultura africana trazida pelos negros escravizados.

O ensino viabilizado pelos padres jesuítas era completamente "desinteressado" pela realidade vivida na colônia. A escola elementar era voltada, então, para a população indígena e para os filhos dos colonos, enquanto a educação média, para os homens da classe dominante. Gradativamente, a ação dos jesuítas passou a se voltar mais para a educação da elite. Segundo Romanelli (1978), a catequese, principal obra da Companhia de Jesus, acabou cedendo lugar à educação elitizada e, com essa característica, conseguiu se firmar no Brasil, mesmo depois da expulsão dos padres, ocorrida no século XVIII. A educação jesuítica excluía o povo e por causa dela o Brasil se tornou um "país da Europa" por muito tempo, já que seus olhos estavam sempre voltados para fora, valorizando a cultura intelectual européia, fazendo da educação brasileira espaço alienado e alienante. Esse modelo de educação, transformada em educação de classe, sobreviveu por todo o período colonial, imperial e afetou o período republicano.

O Esquema 8 expõe graficamente o tipo de visão que influenciou o ensino no Brasil colônia.

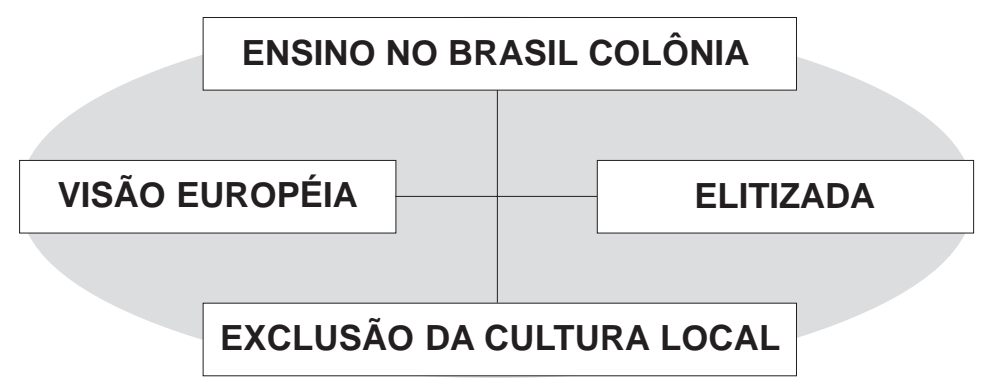

ESQUEMA 8

ENSINO NO BRASIL COLÔNIA 
Fica evidente que o Brasil, nesses primeiros séculos, caminhou alheio, em sua formação, especialmente no sentido educativo, às transformações que já se operavam na Europa, principalmente no século XVII. Nessa época, o pensamento europeu já começava a pôr em dúvida os princípios da fé e da revelação divina frente ao papel do homem (tendência antropocêntrica - o ser humano é responsável por todos os seus processos) como portador de capacidade racional que discerne, distingue e compara. Essa dúvida impulsionou a compreensão do sujeito do conhecimento, debate dominante na Modernidade.

O pensamento moderno científico, elaborado principalmente pela reflexão de René Descartes (1596-1650), põe em discussão a teoria do conhecimento e focaliza o método, ou seja, os procedimentos a serem utilizados pela razão em busca da verdade universal, certa e absoluta. Em seu estudo sobre o método, ele duvida de muitos processos; só não duvida de seu próprio ser racional: "penso, logo existo". Neste sentido, o homem racional se torna verdadeiro e superior a todas as coisas, inclusive ao seu próprio corpo, já que o pensamento é o que constitui o sujeito na sua compreensão.

Nessa perspectiva, Descartes (2002) sente-se “autorizado" a sistematizar a defesa de que o ser humano é puro pensamento. Ser que faz a "experiência mental". Em sua Antropologia Filosófica, ele apresenta um eu pensante que permanece, mesmo que se the extraia o próprio corpo. Este eu permanece, ainda que sejam eliminados o mundo e o espaço. O que dá a identidade do sujeito moderno/cartesiano é o pensamento. Em sua compreensão, mesmo que faltasse tudo (mundo, espaço, corpo) o pensamento permaneceria. O pensamento, com um método rigorosamente organizado e sistematizado alcança a verdade. $\mathrm{Na}$ modernidade, esse interesse pelo conhecimento e pelo método usado para atingi-lo, vai também influenciar a Pedagogia. A busca de métodos certos, seguros, rápidos, 
agradáveis e eficazes na vida prática da escola passa a ser discussão central na educação.

Segundo Cambi (1999, p. 302):

[...] a mente é cogito, pensamento autoconsciente, autoevidente e organizado analiticamente segundo a mecânica das idéias claras e distintas que se agregam de modo lógico, seguindo as regras da não-contradição e da implicação [...] O cogito é independente das paixões, desprovido de emoções, livre de perturbações. Estamos diante de uma mente entendida no sentido espiritualista (contra a matéria-natureza, conotada de interioridade e autotransparência), mas também no sentido matemático (organizada segundo um modelo analítico-geométrico). Essa mente é depois colocada como base da própria ciência da natureza, a qual - na extensão deve fixar os seus caracteres analíticos coordenados entre si segundo procedimentos mecanicistas. Essa idéia de mente [...] terá uma essencial importância pedagógica e influenciará sobre a concepção dos estudos, sobre os processos de aprendizagem escolar, sobre o modelo de homem que muita cultura pedagógica ligada ao racionalismo - irá elaborar.

É nesse contexto, referido por Cambi (1999), que João Amós Comênio (1592-1670), denominado de o maior educador e pedagogo do século XVII, começa a desenvolver uma Ciência da Educação. Em sua obra Didática Magna, preocupa-se em atingir os métodos modernos em educação e a partir de seu pensamento tem início a sistematização da Pedagogia e da didática no Ocidente. Sua proposta centra-se em um modelo de Pedagogia explicitamente epistemológico, científico, super-racional. Comênio propõe um corte radical com o modelo de escola até então praticado pela Igreja Católica. O que ele desejava era ensinar tudo a todos, seguindo os critérios do método moderno instaurado por Descartes. "[...] a universalidade da educação contra as restrições devidas a tradições e a interesses de grupos e de classes, e sua centralidade na vida do homem e da sociedade." (CAMBI, 1999, p.281), seria a principal meta de sua proposta. Porém, apesar de centrar sua análise na vida do 
homem e da sociedade, esta centralidade do homem só é possível, em sua compreensão, quando da consideração de um ser supremo que concebe este homem racional. A racionalização de todas as ações educativas era foco de sua atenção.

Essa didática proposta por Comênio objetiva fazer da aprendizagem um processo de grande eficácia e apresenta como preocupação tarefas cuidadosamente organizadas: ensinar e aprender com segurança para obter bons resultados. Em busca do verdadeiro estudo, põe os sujeitos que ensinam e aprendem em uma relação de superioridade frente à experiência. Apesar de tomar a experiência como fonte do conhecimento, é a razão que, metodicamente organizada, possibilitará a chegada ao conhecimento seguro.

Ensinar tudo a todos fortalece um dos maiores princípios modernos: a universalização. As palavras de Comênio são significativas:

Importa-se agora demonstrar que, nas escolas, se deve ensinar tudo a todos. Isto não quer dizer, todavia, que exijamos de todos o conhecimento de todas as ciências e de todas as artes (sobretudo se se trata de um conhecimento exato e profundo) [...] Desejamos que o método de ensinar atinja tal perfeição que, entre a forma de instruir habitualmente, apareça claramente que vai a diferença que vemos entre a arte de multiplicar os livros, copiando-os à pena, como era uso antigamente, e a arte da imprensa, que depois foi descoberta e agora é usada. Efetivamente, assim como a arte tipográfica, embora mais difícil, mais custosa e mais trabalhosa, todavia é mais acomodada para escrever livros com maior rapides, precisão e elegância, assim também este novo método, embora a princípio meta medo com as suas dificuldades, todavia, se for o aceito nas escolas, servirá para instruir um número muito maior de alunos, com um aproveitamento muito mais certo e com maior prazer, que com a vulgar ausência de método. (ARANHA, 1996, p.113, grifos nossos).

A universalização dos sujeitos, mediatizada pelo método perfeito, rigoroso, rápido e certo organiza, portanto, a didática do educador moderno. O pensamento científico ocidental de Comênio 
exerce grande influência na Pedagogia. O Esquema 9 representa os fundamentos da pedagogia científica na época moderna:

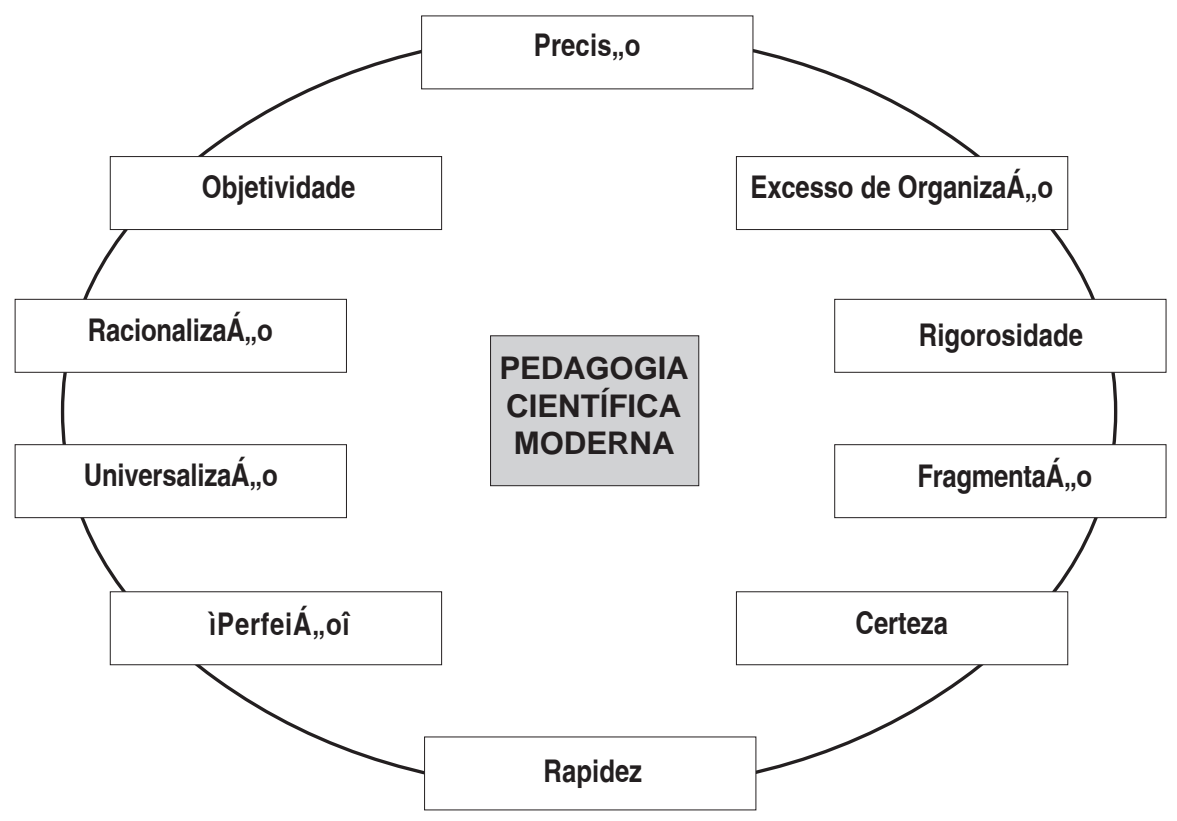

ESQUEMA 9

Fundamentos da Pedagogia Científica Moderna

No Brasil, essas idéias tardaram a chegar em relação à sua discussão e vigência na Europa, que desde o século XVII já se validava, sendo fortalecida no século XVIII, conhecido como "O século das Luzes". O poder da razão humana de interpretar e organizar verdadeiramente o mundo culminou com o ideário positivista do século XIX, disseminado por seu fundador Augusto Comte (1798-1857). O positivismo fortaleceu o avanço da Ciência Moderna quando instituiu a ciência como único conhecimento válido e, portanto, reducionista e excludente. O século XIX foi marcado pelo 
cientificismo pautado no método (concepção determinística de causa e efeito também para o comportamento humano) das ciências da natureza, que priorizava a observação, a matematização e a experimentação. Em educação, coube a Émile Durkheim (1858-1917), a partir de uma visão sociológica, validar esses pressupostos.

Nesse contexto, o pensamento científico ganha a guerra contra o discurso da igreja pela prerrogativa de "falar a verdade" de maneira comprovada. A Ciência Moderna se alia à técnica, ao ensino, à cultura e à indústria e produz discursos abstratos potentes, validados e veiculados, principalmente, no interior das instituições (SILVEIRA, 1999). A escola será uma delas. Por já ser construída em bases excludentes, a escola elementar baiana fortalece essa base, agora apoiada pelo discurso científico.

Apesar de a educação brasileira ainda estar vivendo sob a égide da educação de fundamento cristão (da escolástica da Idade Média), começa a assumir, mesmo que tardiamente se comparado à Europa, os fundamentos da Ciência Moderno-Ocidental, principalmente com a defesa de Comênio e Durkheim, enquanto pensamento pedagógico.

Edificada sobre os fundamentos organizadores da Ciência Moderna, a escola do ensino fundamental, já no século XIX, colabora com uma visão na qual está evidenciado um modelo explicativo unitário de mundo (o mundo ocidental/europeu), interpretado a partir de princípios mecanicistas, a fim de elaborar um projeto laico e científico para o ser humano moderno. A escola elementar, de pensamento cristão, já excluía grupos e discursos diferentes daqueles hegemonicamente eleitos, e com a Ciência Moderna valida essa exclusão com toda força. Nesse caso, após o período abolicionista, os negros já iniciavam o processo de integração à escola institucionalizada, ainda que a cultura africana tivesse sido excluída desses espaços.

O Ensino Fundamental (ou elementar) na Bahia de hoje, apesar dos esforços de tantos pensadores, críticos desse modelo de 
ciência e de prática pedagógica, na consideração da realidade histórica brasileira, ainda perpetua como fundamentos os mesmos princípios da Ciência Moderna.

Cabe então retomar a pergunta formulada no início deste capítulo: "Por que a escola sente calafrio e repulsa pelas singularidades carnais, pela experiência mundana dos sujeitos?" A resposta diz respeito diretamente à visão de universalidade de ser humano, conceituado como pura racionalidade, e à produção dos discursos científicos tomados como verdadeiros. A Ciência Moderna se compreendeu como saneadora das maželas do mundo, sejam elas relativas à situação econômica, política, cultural, racial e de gênero. Como organizadora da humanidade, ela precisava colocar ordem no caos planetário, na diversidade, na diferença e impor a autoridade dos seus superiores naturais, pela força e pela razão (SILVEIRA, 1999). A escola não estava alheia a essa defesa. Destacamos aqui um dos discursos que afetam diretamente a infância afrodescendente e à sua cultura. Validando o desejo da metrópole portuguesa, em embranquecer o Brasil, o discurso científico pautado no racismo chega às escolas para negar a diversidade humana, sempre validado pelos métodos já descritos.

A Ciência Moderno-Ocidental se utilizou do conceito de raça, pondo sob o holofote a raça branca como superior (discurso bem favorável para a metrópole portuguesa frente à sua atuação no Brasil). Em seu discurso, o mundo deveria ser comandado pelo homem branco. Em contrapartida, apresentava as demais como refratárias do progresso, supersticiosas, ignorantes, rotineiras, irresponsáveis, infantis, preguiçosas, despóticas, animalescas, imorais e sanguinárias (SILVEIRA, 1999). Ao homem branco coube a missão civilizadora. O Racismo científico veio acompanhado de uma visão etnocêntrica de mundo, construtora de um discurso discriminatório, no qual a superioridade do sangue "claro e puro" era fato evidente. O desprezo pelo outro impulsionou a política colonial de assimilação social e cultural com imposição do modo europeu de sociedade (no caso do Brasil). 
Fundadas na objetividade e na quantificação (análise de base na biologia: tipo de crânio, quadril, nariz, cor de olhos, altura...) eram produzidas as chamadas "aberrações epistemológicas", que mostravam o lado violento e doentio da Ciência (SILVEIRA, 1999). Separando a humanidade em quatro raças (branco-européia, asiática, americana e africana), a ciência apresentava características de fundo discriminatório e preconceituoso: o branco é um sangüíneo ardente, possui cabelos louros e abundantes, olhos azuis, de traços leves e finos, é de personalidade engenhosa, usa roupas estritas e é regido pelas leis; o asiático é melancólico, severo, avaro, regido pela opinião; o americano é vermelho, colérico, possui cabelos negros lisos e abundantes, narinas amplas, quase sem barba, é teimoso e alegre, erra em liberdade, pinta-se de linhas curvas vermelhas, é regido pelos costumes; e o africano (o mais perseguido) de costumes dissolutos, indolente, vagabundo, preguiçoso, negligente, de cabelos crespos, lábios grossos, pele oleosa, nariz simiesco e é regido pelo arbítrio. O Esquema 10, a seguir, visibiliza as características raciais de base biológica, construídas pela ciência moderna.

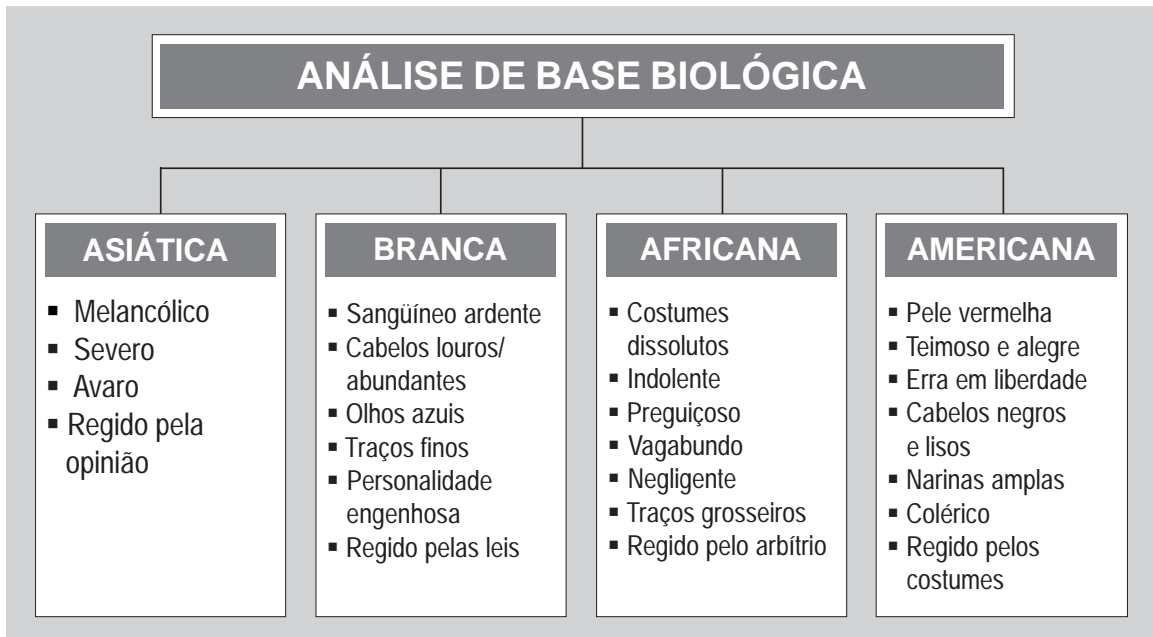


Essas características raciais serviram como critério de verdade na classificação e como determinante das realizações humanas, sociais, políticas e culturais. Daí a colonização intelectual que ocorreu também na escola. A mais bela raça encontra-se na Europa. No Brasil, um dos países formados por "selvagens da América", o povo é conceituado como decadência da natureza americana, chamado de passivo e vítima de um meio ambiente em estado bruto. Alguns cientistas pintavam um retrato divertido e massacrante: africanos sem imaginação, que rejeitavam o progresso e a mudança e sem capacidade de cultivar as próprias terras. Apenas em um ponto esses cientistas afirmaram a superioridade do negro sobre o americano, com ironia picante: o negro é superior em relação à capacidade de cercar as mulheres, aí sim supera a preguiça e a indolência (SILVEIRA, 1999). Esses e outros discursos desqualificadores das culturas diferentes da branco-ocidental, validados pela ciência moderna, afetavam também o pensamento pedagógico, que excluiu de suas elaborações a história e as construções culturais desses outros povos diferentes.

Somado a isto a forma didaticamente pensada de estruturar o ensino, em sua dimensão prática (seriando, separando por idade, por gênero, nivelando formas de conhecer, reduzindo o conhecimento a conteúdos abstratos objetivamente estruturados segundo interesses de pequenos grupos), fez com que a escola adotasse uma atitude de aversão (ou silêncio intencionalmente colocado) frente às condições carnais dos sujeitos, fazendo-os separar-se de sua experiência produzida no mundo da vida.

Ainda hoje, em pleno século XXI, essa forma científica de pensar os sujeitos ainda se faz muito presente na escola de ensino fundamental no contexto baiano, visto que a cultura africana, valorizada pelos seus descendentes na Bahia, ainda se encontra na zona da exclusão. O pensamento científico e a ação pedagógica ainda não conseguiram contemplar o sujeito afrodescendente em suas 
elaborações. Na Bahia, segundo dados do IBGE (2003), de uma população que totaliza 13.085.769 de habitantes, 9.574.018 são negros e pardos (os que assim se nomearam), maioria, portanto. Dessa maioria de habitantes, uma grande parcela valoriza efetivamente a cultura africana. No ensino fundamental baiano freqüentam 3.217.108 crianças (de maioria negra), que ainda não se vêem contempladas nesta ciência da educação (IBGE, 2003).

Nesse sentido, é preciso repensar os modos de produção de ciência da educação e sua compreensão de verdade, falsidade, de racional e irracional. A educação baiana ainda mantém e perpetua formas "duras", "positivas" de conhecimentos importados das formas de produção da ciência. Pensar, então, como a criança afrodescendente produz o conhecimento, de modo que não fortaleça o modelo de Ciência Moderna, é validar a linguagem da possibilidade de construções, reconstruções e re-significações e do reconhecimento de uma epistemologia crítica nos cenários educacionais; é reconhecer, assim como nos alerta Macedo (2000, p.31), que a "[...] construção do saber carrega tudo que lhe é próprio: contradições, paradoxos, ambigüidades, ambivalências, assincronias, insuficiências, transgressões, traições, etc."

A transformação epistemológica na Educação, partindo do Ensino Fundamental, deve compreender o ser humano e a sua produção de conhecimento a partir de uma cosmovisão que valorize os aspectos culturais, sociais, emocionais, políticos e históricos dos sujeitos. Ampliar as possibilidades de uma educação cada vez mais humanizante nesse nosso tempo, desconstruindo a visão etnocêntrica construída pela Ciência Moderna, bem como repensar o seu método, a sua didática, é uma das principais tarefas da Pedagogia contemporânea. Na Bahia, marcada pelos valores e princípios africanos, faz-se ainda mais urgente, para que não seja vivido mais um século de exclusões e silenciamentos no interior da escola. 


\subsection{ESCOLA DA PRESENÇA E DA SOLIDARIEDADE}

Para que a escola se transforme de cenário de representações, de negações e exclusões étnicas (e raciais) em espaço de presença e solidariedade, há um difícil e longo caminho a percorrer, visto que, em sua base estrutural, o discurso que organiza a sua prática, ainda que no plano oculto, é o monológico. A escola ainda não sabe ou não está disposta a lidar com a diferença. A consideração da diferença e da diversidade não é fato no cotidiano do ensino fundamental baiano.

A negação da afrodescendência (bem como da cultura cigana, indígena...), nesse contexto, chega a “escandalizar”, já que está situada numa região em que predominam esses sujeitos. Isto significa dizer que a escola baiana de ensino fundamental vem desenvolvendo um ensino pautado na abstração e no apagamento étnico da maioria daqueles que vivem essa experiência. Esse ensino, como no século XIX, ainda perpetua o discurso implícito, favorecedor da cultura ocidental branco-européia, e apresenta dificuldade de dialogar com o diferente. Neste sentido, torna-se necessário pôr essa escola em discussão na tentativa de re-significá-la, de maneira não convencional, enquanto espaço de solidariedade, para que a diferença seja, de fato, contemplada. Saber incluir a diversidade, a diferença, é a tarefa da escola contemporânea ${ }^{16}$.

O termo solidariedade é aqui entendido como ato de se remeter ao desenvolvimento grupal e pessoal de valores que possibilitem uma aproximação intelectual e prática de situações, em que se percebe o outro em posição desfavorável, com a intenção de ajudar a superá-las. Esta superação garante o desenvolvimento da consciência/vivência de que direitos sociais existem e devem ser garantidos a todos num contexto democrático. A solidariedade, por não ser uma predisposição "natural" do ser humano, precisa ser desenvolvida, construída cotidianamente, já que o contexto cultural (prin- 
cipalmente o de base ocidental) afastou-nos da prática solidária. Neste sentido, é preciso que os limites éticos e educacionais impostos a partir dessa formação não-solidária sejam superados.

Para nos tornarmos solidários com o outro, o "diferente", é preciso "[...] ascender a um estágio de consciência e opção, que implica numa conversão a valores, que não são óbvios em nossa experiência cotidiana." (ASSMAN; SUNG, 2000, p.31). Pôr os valores para dialogar é imprescindível numa prática solidária. E, nesse diálogo, espera-se que o solidário tome para si questões que nem sempre são suas e responsabilize-se por elas. Afinal, em uma prática solidária, a base da "luta" são os ideais sociais coletivos. Nessa perspectiva, a escola solidária compreenderá que a causa das crianças afrodescendentes (ou das ciganas, indígenas, entre outras...) também é sua e buscará aprender cuidados específicos para elas, sem dar a esta ação uma configuração puramente sócio-afetiva. Ao contrário, é preciso compreendê-la como um ato sócio-político e não omisso frente à história dessas crianças. A exclusão e a negação desse grupo cultural devem ser superadas.

Segundo Assman e Sung (2000, p.79):

[...] a cultura na qual nós vivemos nos abre e fecha as "janelas" pelas quais vemos o mundo. Ela nos leva a vermos certos aspectos da realidade e não vermos outros; mais ainda, leva-nos a não perceber que não vemos esses outros aspectos. Como não temos consciência de que não vemos um determinado aspecto da realidade, cremos que o que vemos é toda a realidade ou toda a verdade [...] Assim, os problemas dos indivíduos e dos grupos sociais são compreendidos como problemas isolados que dizem respeito somente aos interessados e que devem ser solucionados por estes, sem nenhuma responsabilidade por parte do resto da sociedade.

É nesse sentido que a Escola Fundamental ainda pensa os sujeitos. Que cada um resolva as suas questões de natureza sóciocultural e política fora de seus domínios, porque acredita ser res- 
ponsável apenas por desenvolver habilidades formais como, por exemplo, ler, escrever, raciocinar, contar etc.

Entendemos que assumir uma prática solidária frente a esses outros diferentes representa também um abalo, uma perturbação na estrutura desejada pela escola, visto que promove incômodo, embaraço e, ao mesmo tempo, obriga-a a transformar a sua visão de mundo e agir sobre ele. Integrar experiências tão diversas, saber cuidar delas não é nada confortável, já que exige mudanças fundamentais no interior e na organização das práticas escolares.

Solidariedade tem relação com a forma de ver o mundo. A lente deve ser a consideração da alteridade. Reconhecer o outro em sua diferença e singularidade. No entanto, para isso, como dizem Assman e Sung (2000), é preciso se "despir" das certezas culturais incorporadas. É preciso duvidar dessas certezas. Duvidar das certezas culturais constitui-se em uma condição epistemológica necessária à pratica da solidariedade. Isto implica em considerar a incerteza da realidade dada, em si, duvidar dos rótulos sociais, das classificações de humanidades e de culturas como melhores ou piores; duvidar se existe um melhor conhecimento, raça ou etnia, enfim, pôr em dúvida certos conceitos e explicações construídos ao longo da história e que se validam ideologicamente em nosso cotidiano escolar.

É preciso que a Escola compreenda a criança afrodescendente enquanto sujeito que tem direito de possuir uma identidade, de manifestar as suas crenças, seus valores e hábitos, sua história. A Escola precisa realizar um trabalho sensível e amoroso, a fim de "instituir" essa ação solidária como fundamento de sua prática pedagógica. Solidariedade como ato amoroso e sócio-político deve ser um dos fundamentos do processo de conhecer e da ação que ajuda a marcar a humanidade na tarefa docente.

A prática pedagógica solidária deve colaborar com essa criança para que ela possa ser um "ser de presença". Este, segundo Heidegger 
(1996, 2002), significa Ser que vive a experiência autêntica, sem cortes e hierarquias frente à produção de conhecimento racional. Isto significa dizer que à Pedagogia e à escola não cabe transformar essa criança num ser de representações, forçada a produzir conhecimentos completamente abstratos, sujeito sem corpo, sem história, afastado da experiência, negado em sua condição de vida, "fantasmas ou aparições sociais" (LÉVI-STRAUS, 1976). Compreender a criança afrodescendente como presença, é entendê-la como corporeidade viva no mundo. É entendê-la como um ser em busca de esclarecimento sobre si, em sentido ontológico, a partir das relações tensivas e conflitivas com o outro. O ser-no-mundo, o Dasein heideggeriano, ou o ser aí com os outros lançados no mundo, que vive a experiência antes que ela se transforme em abstração, em puro conceito.

Uma escola e uma Pedagogia solidárias devem assumir, diante dos educandos, neste caso os afrodescendentes, no mínimo, uma atitude de não-indiferença. Segundo Costa (1999), quando deixamos de ser indiferentes diante de algo ou alguém, aquilo ou aquele assume para nós um valor que pode ser positivo ou negativo, a depender não só da forma como compreendemos o mundo e os sujeitos que constroem esse mundo, como também da forma como dialogamos com ele. Uma escola solidária é aquela que abraça seus educandos em sua condição de vida e ajuda-os a transcender a condição de exclusão e violência; é aquela que não nega nem discrimina a diferença, ao contrário, toma essa diferença como riqueza e possibilidade de dialogias não lineares, não homogêneas. Não ser indiferente rompe com a idéia do só faço o que épuramente escolar que na escola "[...] nada seja experimentado como estranho à sua vida própria [...]" (JAPIASSU, 1999, p. 33).

É preciso acreditar que os problemas que podem parecer estranhos ou afastados do educador são também de sua responsabilidade e, por isso, cabe-lhe buscar as ações individuais/coletivas para a sua resolução. É preciso buscar perceber as "zonas de sombra", 
os problemas que dificultam o viver cotidiano na escola. O alerta de Japiassu (1999, p.34) é útil: “[...] se não percebermos as zonas de sombra que ofuscam o nosso sistema educacional atual, ele continuará provocando, na expressão de Castoriadis, 'uma desorientação informe das novas gerações'." Essas zonas de sombra ofuscam, no processo escolar, as dimensões mais profundas presentes na vida dos sujeitos que participam dele: étnicas, culturais, políticas, sociais, religiosas. É preciso que a Escola, através também de uma prática solidária, possibilite às crianças afrodescendentes o desenvolvimento máximo da sua singularidade, expressa em seus mitos, suas vestes, sua música, sua dança...

A consciência da necessidade da solidariedade, que pode ser intelectual e moral, a fim de viabilizar uma prática escolar mais humana une os seres humanos. $\mathrm{O}$ encontro solidário entre educandos e educadores possibilita, conseqüentemente, o encontro de culturas, pessoas e grupos de diferentes origens. Esse encontro pede abertura, simpatia e generosidade.

Considera-se, ainda, que uma escola solidária necessita da prática dialógica e crítica. Paulo Freire (1996) considerou o diálogo como um dos maiores fundamentos da prática pedagógica. Não aquele diálogo compreendido como mera troca de palavras entre partes, esvaziadas de sentido e de implicação político/crítica. Ao contrário, na perspectiva desse educador, dialogar é a capacidade humana de incluir o outro, mediatizada pela linguagem. Só a ignorância dos ritos, valores, costumes do outro e a arrogância preconceituosa dificultam o diálogo favorável à solidariedade. Todo diálogo implica na abertura do "falante" para o "ouvinte" e vice-versa. Freire (1996, p.136) enuncia:

Testemunhar a abertura aos outros, a disponibilidade curiosa à vida, a seus desafios, são saberes necessários à prática pedagógica. Viver a abertura respeitosa aos outros e, de quando em vez, de acordo com o momento, tomar a própria prática de abertura ao outro como objeto de reflexão crítica deveria fazer parte da 
aventura docente. A razão ética da abertura, seu fundamento político, sua referência pedagógica; a boniteza que há nela como viabilidade do diálogo [...] O sujeito que se abre ao mundo e aos outros inaugura com seu gesto a relação dialógica em que se confirma como inquietação e curiosidade, como inconclusão em permanente movimento na História.

A escola solidária, nesta perspectiva, toma o diálogo em sua natureza interativa e aberta à possibilidade do acordo livre e capacita-se a incluir o outro na diferença. Neste sentido, dialogar com a afrodescendência, garantindo a sua presença na escola, é estar disponível para assumir a diversidade e se refazer permanentemente, principalmente no sentido de negar o discurso ideológico que edifica, ainda hoje, a prática escolar. Assman e Sung (2000), consideram que toda comunicação deve ser tecida no diálogo, na elaboração de uma linguagem e de "esperanças comuns". Devese abrir um horizonte que possibilite a incorporação de uma prática solidária a partir do desejo de dialogar com os sujeitos que estão dentro-e-fora da sociedade, do mundo. O mundo de cada um, o mundo de cada grupo social, de cada cultura. Dialogar deve pressupor o reconhecimento mútuo.

Ser solidário com o outro exige convicção, escolha ética e aceitação dos valores e expressões contrárias, diferentes (MORIN, 2000). As pessoas e culturas devem aprender umas com as outras e alcançar a humanidade que há em cada Ser, através dos atos solidários.

Uma escola solidária é também aquela que não está "desinteressada" frente à realidade do seu educando, mas desenvolve cotidianamente a sua capacidade de escuta. Ouve aqueles que sempre têm muito a dizer e a ensinar. Uma escola solidária não é ditadora, autoritária.

Se, na verdade, o sonho que nos anima é democrático e solidário, não é falando aos outros, de cima para baixo, sobretudo, como se fôssemos os portadores da verdade a ser transmitida aos demais, 
que aprendemos a escutar, mas é escutando que aprendemos a falar com eles. Somente quem escuta paciente e criticamente o outro, fala com ele, mesmo que, em certas condições, precise de falar a ele. O que jamais faz quem aprende a escutar para poder falar com é falar impositivamente. Até quando, necessariamente, fala contra posições ou concepções do outro, fala com ele como sujeito da escuta de sua fala crítica e não como objeto de seu discurso. $\mathrm{O}$ educador que escuta aprende a difícil lição de transformar o seu discurso, às vezes necessário, ao aluno, em uma fala com ele. (FREIRE, 1996, p.113, grifos do autor).

O Esquema 11 representa visualmente os fundamentos de uma escola solidária.

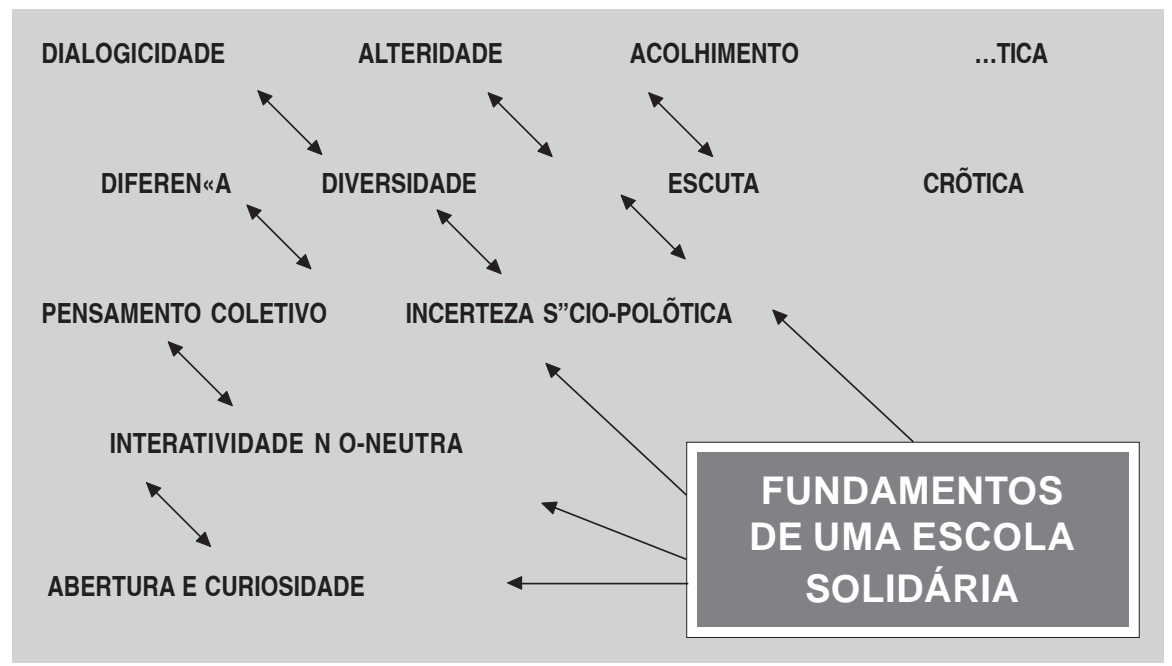

ESQUEMA 11

FUNDAMENTOS DE UMA ESCOLA SOLIDÁRIA

Essa escola solidária, então, é dialógica, aberta à diferença e desenvolve a escuta crítica. Nela é possível considerar o educando não como um favor a ser feito, mas como presença, como 
compromisso ético e ação político/pedagógica implicada no seu contexto de atuação.

Saber da fundamental necessidade de se abrir para a diferença e para a diversidade, viabilizadas pela prática solidária, dialógica, é o desafio posto para a escola baiana contemporânea, visto que o seu contexto, por si só, indica essa necessidade. 


\title{
UMA PROPOSTA COMO CONCLUSÃO:
}

\author{
ENTRE EPISTEMOLOGLA E TRADICCAOO
}

AFRODESCENDENTE

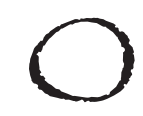

final deste texto não é uma conclusão definitiva e inalterável, visto que se apresenta muito mais como um horizonte que se abre para uma "virada epistemológica" no contexto da Educação do Estado da Bahia e do Brasil. Mas este horizonte é impregnado de sentidos e significados e carrega a esperança, mais que a certeza, de ver as transformações se efetivando no Ensino Fundamental. Este horizonte se abre em algumas direções como conseqüência das reflexões desenvolvidas nesta obra.

A primeira direção é delineada pela constatação de que a Ciência da Educação, no contexto baiano, amparada pela epistemologia produzida pelo educador, não contempla a produção do conhecimento da infância afrodescendente. As concepções do próprio conceito de infância, desde a visão antiga-ocidental até o processo moderno-colonialista brasileiro, evidenciam os segmentos da infância valorizados ou excluídos pelo discurso político/ideológico de cada época. Este discurso afeta diretamente a compreensão atual acerca dos grupos infantis considerados "melhores" e portadores de "nobreza e direitos". Historicamente, a cultura branca brasileira, marcada pelo etnocentrismo, sempre esteve em posição de vantagem social, política e econômica em detrimento dos grupos negrosafrodescendentes, mestiços e indígenas. A exclusão social e cultural 
desses grupos se dá também na escola, já que esta não vive numa "redoma" e é diretamente afetada pelo discurso ideológico, discriminatório e excludente que funda a sociedade brasileira em relação à cultura desses grupos infantis.

A partir dessa constatação, fez-se necessário trilhar um caminho discursivo, no qual a "descrição densa" de fatos históricos possibilitou uma conceituação da infância afrodescendente e colaborou para uma valorização efetiva dessa cultura, na tentativa de garantir-lhe os direitos outorgados em alguns artigos do Estatuto da Criança e do Adolescente (ECA).

O que é isto - A infância de origem afrodescendente? Este debate aparece no primeiro capítulo e apresenta elementos que definem e caracterizam esse grupo infantil. As relações entre território (Continente Africano e Bahia) e cultura de grupos que se entrelaçam e se reelaboram. Dessas novas relações se constrói a identidade plural e complexa do afrodescendente na Bahia, por ser fruto da pluralidade cultural e territorial desde a África. De forma criativa, a matriz negra africana se mantém e se reelabora significativamente no novo espaço (Bahia), principalmente nos espaços sócio-religiosos, conhecidos como terreiros de Candomblé.

A infância de origem afrodescendente, assim como seus "parentes", realiza uma fundamental tarefa - a reconciliação -, que busca possibilitar a permanência de vínculos com a experiência desde a África. Trata-se da reconciliação com os parentes deixados em África ou separados pelo tráfico negreiro, através dos novos laços de solidariedade e convívio e não mais pelos laços de sangue que os unia anteriormente, bem como reconciliação com os seus ancentrais (nos terreiros, representados pelos Orixás) e seu território. Os afrodescendentes, na Bahia, reconstroem as relações de parentesco, de ancestralidade e de espaço, visto que, no novo mundo, passam a considerar as novas formas de convívio social, político e cultural em que se encontram. A reconciliação une corpo e território enquanto 
cultura, mediados pela memória (canto, língua, dança, culto aos orixás).

Participa ainda da conceituação desse grupo infantil, princípios presentes na figura dos Orixás. Estes, compreendidos como "modelos de identidade" ancestrais, auxiliam a vida cotidiana das pessoas, através de suas posturas e ensinamentos. Alguns são destacados, juntamente com o princípio da Reconciliação, principalmente porque apresentam os princípios considerados fundamentais para um re-significar da epistemologia do educador na escola de ensino fundamental. A Integração e os Novos Padrões de Convivência (Iansã ou Oyá); o Compartilhar (Oxum); o princípio da Criação e da Co-Responsabilidade (Nana e Oxalá); a Multiplicidade, a Diversidade da vida, o Rigor com simplicidade e delicadeza (Oxumaré e Nana); a Força, A Inteligência, a Justiça e o Rigor (Xangô e Oxossi); o Acolhimento (Ibeji); e o Respeito à natureza (Ossanyin). Estes são princípios universais vividos e trabalhados cotidianamente nos espaços religiosos de tradição africana e, por isso mesmo, abertos à incorporação na prática de qualquer sujeito, independentemente de ser ou não membro dos terreiros de Candomblé. Os orixás ${ }^{17}$, com suas posturas, nos ensinam a ser melhores seres humanos.

A segunda direção aponta a Epistemologia do Educador na contemporaneidade, considerando a realidade do ensino fundamental baiano. Mais uma vez, a "Descrição Densa" amplia a compreensão sobre a atual organização da Epistemologia do Educador e o seu principal fundamento. Constatamos que o projeto epistemológico da modernidade supervaloriza o cogito, instituindo a separação sujeito/objeto, fundamento do que se chama de ciência positiva e funcionalista. Ainda é esse fundamento que ampara a epistemologia da maioria dos educadores do ensino fundamental no contexto baiano.

Nas falas das crianças, dos educadores e dos pais, percebemos que é preciso, de fato, que se efetive no cotidiano escolar uma 
Epistemologia Crítica, re-significada em seus fundamentos, que transcenda os limites desse projeto epistemológico moderno, produtor também da razão instrumental. No entanto, algumas barreiras foram identificadas.

A primeira diz respeito à separação sujeito/objeto, como fundamento da Ciência da Educação. A epistemologia do educador, no contexto baiano, não contempla a experiência da criança afrodescendente porque o seu fundamento de base é o cartesianismo. Essa forma de pensar os sujeitos, separado-os de sua experiência vital, acaba gerando o fortalecimento do silenciamento, do preconceito e da negação a que estas crianças estão submetidas. Nesse sentido, elas são apenas produtoras de habitus, visto que lhes cabe apenas produzir representações e idéias abstratas. $\mathrm{O}$ acesso à sua experiência é negado. Colabora para esta situação, o olhar distraído dos educadores sobre a realidade.

A segunda barreira abre espaço para uma reflexão que merece consideração especial. Trata-se da interpretação realizada pela maioria dos educadores sobre epistemologia genética. Essa interpretação impulsiona o olhar linear sobre os sujeitos. Afinal, o peso atribuído à cognição e ao fator biológico desloca para um segundo plano a discussão cultural, étnica, neste caso específico. O biológico é mais importante que o cultural, o social, o político. As "habilidades" cognitivas são, assim, o foco de atenção; ensinar português e matemática, ler, contar e raciocinar é a fundamental preocupação de fundo da Ciência do Educador. Dessa forma, questões que dizem respeito à subjetividade dos sujeitos ficam apagadas no contexto escolar. Com esse discurso, no entanto, não queremos afirmar que desenvolver habilidades cognitivas não é tarefa importante. O desenvolvimento do equilíbrio entre razão e corpo, ser humano e mundo, sujeito e experiência, sem dúvida, deve estar presente na epistemologia do educador.

A terceira barreira revela a intolerância religiosa advinda de preconceito contra as crianças afrodescendentes na escola. Ora, essa bar- 
reira, que não está presente apenas na escola, mas também na realidade brasileira, possibilitou-nos perceber que esta sociedade parece se fundar em antigas práticas medievais, "acusações e cremação verbal" da diferença religiosa, principalmente relativa à religiosidade de tradição africana. Os praticantes do Candomblé são "perseguidos" e discriminados, segundo fala dos próprios sujeitos que vivem essa realidade (tanto crianças como pais). Mais uma vez, o etnocentrismo aparece, agora revelado em relação às práticas religiosas. Também se vê que o ECA, em seu artigo 16, é completamente descumprido, quando afirma que deve ser garantido o "[...] direito de liberdade da criança e do adolescente, nos aspectos de opinião e expressão, crença e culto religioso, participar da vida familiar e comunitária, sem discriminação." (DARLAN, 1998, p.21). Essa intolerância, aliada à discriminação e ao preconceito, dificulta a constituição de uma epistemologia crítica e incita a permanente discussão.

A quarta barreira constatada está relacionada a atual configuração da escola. Esta é perversa, por ter sido fundada a partir de um discurso científico que a afetou e produziu historicamente. A Escola e a Pedagogia que conhecemos precisam ser re-significadas e edificadas em bases que reconheçam a presença e a solidariedade e superem o pensamento etnocêntrico presente desde as suas raízes. Também o método, a didática, possibilitados pelas condições de formação dos educadores, dificulta o trabalho solidário que inclua a diferença.

Nas falas de alguns educadores, fica clara a preocupação com o método e a dificuldade de trabalhar com a diferença e a diversidade. Este fato é preocupante porque atesta a forma como o educador do Estado da Bahia vem sendo formado (desde os cursos de formação no magistério, graduação nos cursos de Pedagogia até os momentos de formação continuada). Durante esse processo, não aprofundam o conhecimento sobre Ciência da Educação, principalmente na consideração do próprio contexto cultural (na Bahia, a maioria é negra-afrodescendente). 
Se a epistemologia valorizada pelos educadores do ensino fundamental e, conseqüentemente, pela escola baiana, não contempla a produção de conhecimento da criança afrodescendente, importante seria re-significá-la. Deste modo, esta obra sugere a abertura de um horizonte para uma "virada epistemológica" no ensino fundamental do Estado da Bahia. A proposta se organiza tomando como fundamento inicial a Reconciliação, articulada com princípios valorizados nos espaços de tradição religiosa africana, a fim de propor reflexão radical sobre o principal fundamento do projeto epistemológico moderno, que influenciou diretamente a Ciência da Educação.

Essa "virada epistemológica", no entanto, não garante uma mudança radical na prática e na estrutura escolar - afinal depende também de vontade política, da reestruturação de paradigmas sociais - mas possibilita reflexão profunda para aqueles que vivem cotidianamente a educação. Essa abertura de horizonte, embora não suficiente, é necessária para uma educação que assuma como base a diferença e a diversidade em seus amplos e múltiplos aspectos. 


\section{REFERENCLAS}

ABBAGNANO, Nicola. Dicionário de Filosofia. São Paulo: Martins Fontes, 2003.

AGEA, Luiz Roberto. Epistemologia básica e suas aplicações em Ciências da Saúde. 2002. 70 f. Dissertação (Mestrado em Ciências da Saúde) - Universidade do Vale do Itajaí. Itajaí, 2002.

AGIER, Michel. Anthropologie du Carnaval. La ville, la féte et l'Áfrique à Bahia. Paris: Éditions Parenthèses, 2000.

ARANHA, Maria Lúcia de Arruda. História da Educaşão. 2. ed. São Paulo: Moderna, 1996.

ARAÜJO, Ubiratan Castro de et al. II Centenário da Sedição de 1798 na Babia. Salvador: Academia de Letras da Bahia; Secretaria de Cultura e Turismo; Brasília: MINC, 1999.

ARIÉS, Philippe. História social da criança e da família. Tradução de Dora Flaksman. Rio de Janeiro: LTC, 1981.

ASSMAN, Hugo; SUNG, Jung Mo. Competência e sensibilidade solidária: educar para a esperança. Petrópolis, RJ: Vozes, 2000. BACHA, Márcia Neder. Escola moderna, purgatório das paixões. Mato Grosso do Sul, 2004. Disponível em: <http:www2.uol.com.Br/ percurso/main/pcs/BachaEscola.htm $>$ Acesso em: 20 maio 2004. 
BOMBASSARO, Luiz Carlos. As fronteiras da Epistemologia: como se produz o conhecimento. Petrópolis, RJ: Vozes, 1992.

BOURDIEU, Pierre. A economia das trocas simbólicas. Tradução de Sérgio Miceli et al. São Paulo: Perspectiva, 2001.

BRASIL. Presidência da República. Casa Civil. Subchefia para Assuntos Jurídicos. Lei $N^{0}$ 8.069, de 13 de julho de 1990. Dispõe sobre o Estatuto da Criança e do Adolescente e dá outras providências. Disponível em: <http://www.planalto.gov.br/ ccivil_03/Leis/L8069.htm> Acesso em: 18 nov. 2003.

BRASIL. Presidência da República. Lei n 10.639, de 9 de janeiro de 2003. Altera a Lei no 9.394, de 20 de dezembro de 1996, que estabelece as diretrizes e bases da educação nacional, para incluir no currículo oficial da Rede de Ensino a obrigatoriedade da temática "História e Cultura Afro-Brasileira", e dá outras providências. Disponível em: <http://

www.educacaopublica.rj.gov.br/biblioteca/documentos/ doc13c.htm> Acesso em: 17 jul. 2004.

CAMBI, Franco. História da Pedagogia. São Paulo: UNESP, 1999.

CASHMORE, Ellis. Dicionário de relações étnicas e raciais. Tradução de Dinah Kleve. São Paulo: Summus, 2000.

CASTELLS, Manuel. O poder da identidade. O poder da informação: economia, sociedade e cultura. 3. ed. São Paulo: Paz e Terra, 2002. Vol. 2.

CHAUÍ, Marilena. Convite à Filosofia. 8.ed. São Paulo: Ática, 1997. CORTES, Maria Inês. Tradição e oralidade: a Bahia como espaço de recriação da memória. Texto apostilado de Palestra realizada no Centro de Estudos Afro-Orientais. Salvador, out. 2002.

COSTA, Antonio Carlos Gomes da. A presença da Pedagogia. Teoria e prática da ação socioeducativa. 2. ed. São Paulo: Global; Instituto Ayrton Senna, 1999. 
DARLAN, Siro. Estatuto da Criança e do Adolescente. Lei $n^{\circ}$ 8.069/ 90. Rio de Janeiro: DP\&A, 1998.

DELEUZE, Gilles; GUATTARI, Félis. O que é a Filosofia? São Paulo: Editora 34, 1992.

DESCARTES, René. Discurso do Método: para bem conduzir a própria razão e procurar a verdade nas ciências. Tradução de Thereza Christina Stummer. São Paulo: Paulus, 2002.

FREIRE, Paulo. Educação como prática de liberdade. Rio de Janeiro: Paz e Terra, 1967.

- Pedagogia da autonomia: saberes necessários à prática educativa. São Paulo: Paz e Terra, 1996.

FREITAS, Joseania Miranda. A bistória da biblioteca infantil Monteiro Lobato: entrelaçamento de personagens e instituição. 2001. 288 f. Tese (Doutorado em Educação) - Faculdade de Educação, Universidade Federal da Bahia. Salvador, 2001.

FUNARI, Pedro Paulo de Abreu. A arqueologia de Palmares: Sua contribuição para o conhecimento da história da cultura afroamericana. In: REIS, João José; GOMES, Flávio dos Santos (Orgs.). Liberdade por um fio. História dos quilombos no Brasil. São Paulo: Companhia das Letras, 1996. p.26-51.

GALEFFI, Dante Augusto. Delineamentos de uma filosofia do educar polilógica: no caminho de uma ontologia radical. Salvador, 2002. . Filosofar e educar. Salvador: Quarteto, 2003.

GHIRALDELLI JR. Paulo. As concepções de infância e as teorias educacionais modernas e contemporâneas. Revista do Centro de Educação, Santa Maria, RS, UFSM, v. 25, n. 1, dez./jan./ jul. 2000. Disponível em: <http://www.ufsm.br/ce/revista/ revce/2001/02/a2.htm> Acesso em: 18 jul. 2003.

HEIDEGGER, Martin. Ser e Tempo. 12. ed. Parte I. Tradução de Márcia Sá Cavalcante Schuback. Petrópolis, RJ: Vozes, 2002. 
- Conferências e escritos filosóficos. Tradução e Notas de Ernildo Stein. São Paulo: Abril Cultural, 1996. (Coleção Os Pensadores).

IBGE - Instituto Brasileiro de Geografia e Estatística. Censo Demográfico - 2000 - Resultados da Amostra - População residente, por religião, segundo as Grandes Regiões e as Unidades da Federação. Disponível em: <http://www.ibge.gov.br/home/ estatistica/populacao/censo2000/primeiros_resultados_amostra/ grandes_regioes/pdf/tabela_2_1_2.pdf> Acesso em: 18 maio 2003.

JAPIASSÚ, Hilton Ferreira. Um desafio à educação: repensando a Pedagogia Científica. São Paulo: Letras \& Letras, 1999.

JESUS, Luciana Maria de; BRANDÃO, Helena Nagamine. Mito e tradição indígena. Gêneros do discurso na escola: mito, conto, cordel, discurso político, divulgação científica. São Paulo: Cortez, 2000. v.5.

LÉVI-STRAUS, Claude. Raça e História. In: - Antropologia estrutural dois. São Paulo: Tempo Brasileiro, 1976. p.41-51.

LIMA, Vivaldo da Costa. A família de santo nos Candomblés Jêje-Nago da Bahia: um estudo de relações intragrupais. Salvador: Corrupio, 2003.

LUZ, Marco Aurélio. Agadá. Dinâmica da civilização africanobrasileira. 2.ed. Salvador: EDUFBA, 2000.

MACEDO, Roberto Sidnei. A etnopesquisa crítica e multirreferencial nas ciências humanas e na educação. Salvador: EDUFBA, 2000.

MACHADO, Vanda. Ilê Axé. Vivências e invenção pedagógica. As crianças do Opô Afonjá. Salvador: EDUFBA, 1999.

MARCÍLIO, Maria Luiza. História social da criança abandonada. São Paulo: Hucitec, 1998. - A lenta construção dos direitos da criança brasileira. - século XX. Biblioteca virtual de Direitos Humanos da Universidade de 
São Paulo. Comissão de Direitos Humanos Disponível em:

<direitoshumanos@usp.br> Acesso em: 23 out. 2004.

MORIN, Edgar. Os sete saberes necessários à educação do futuro. 2 .ed. São Paulo: Cortez, 2000.

; CIURANA, Emílio-Roger; MOTTA, Raúl Domingo.

Educar na era planetária: o pensamento complexo como método de aprendizagem pelo erro e incerteza humana. São Paulo: Cortez, 2003.

MOSCOVICI, Serge. A representação social da Psicanálise. Rio de Janeiro: Zahar, 1970.

MOTA, Carlos Guilherme. Viagem incompleta. (1500-2000).

Formação: histórias. A experiência brasileira. 2. ed. São Paulo: Editora SENAC, 2000.

NABOKOV, Vladimir. Lolita. São Paulo: Companhia das Letras, 1994.

OLIVEIRA, Eduardo. Cosmovisão africana no Brasil: elementos para uma filosofia afrodescendente. Fortaleza: LCR, 2003.

PAI ARI de Ajagunã e o Candomblé da Bahia. Disponível em: $<$ http:/ / ajagunacultura.sites.uol.com.br/ > Acesso em: 30 abr. 2004.

PILOT'TI, Francisco. Crise e perspectivas da assistência à infância na América Latina. In: PILOTTI, Francisco; RIZZINI, Irene (Orgs.). A arte de governar crianças. A história das políticas sociais, da legislação e da assistência à infância no Brasil. Rio de Janeiro: Editora Universitária Santa Úrsula, 1995. p.10-45.

PONCZEK, Roberto Leon. Reflexões sobre a descentralização ontológica do mundo em Spinoza e Heidegger: uma proposta cosmopedagógica. Texto apresentado por meio de divulgação digital como proposta de avaliação da disciplina Filosofia e Educação, na FACED -UFBA. Salvador, 2003. 
PRANDI, Reginaldo. Os príncipes do destino. Histórias da mitologia afro-brasileira. São Paulo: Cosac \& Naity, 2001.

REIS, João José; GOMES, Flávio dos Santos. Introdução. In: REIS, João José; GOMES, Flávio dos Santos (Orgs.). Liberdade por um fio. História dos quilombos no Brasil. São Paulo: Companhia das Letras, 1996. p.9-25.

RODRIGUÉ, Maria das Graças de Santana. Orí Àpéré Ó. O ritual das águas de Oxalá. São Paulo: Summus, 2001.

ROMANELLI, Otaíza de Oliveira. História da educação no Brasil. Petrópolis, RJ: Vozes, 1978.

ROUSSEAU, Jean-Jacques. Emílio ou da educação. Tradução de Roberto Leal Ferreira. 2.ed. São Paulo: Martins Fontes, 1999. SANTOMÉ, Jurjo Torres. As culturas negadas e silenciadas no currículo. In: SILVA, Tomáz Tadeu da (Org.) Alienígenas na sala de aula. Petrópolis, RJ: Vozes, 1995. p.159-179.

SANTOS, Boaventura de Souza. Pela mão de Alice: O social e o político na pós-modernidade. São Paulo: Cortez, 1996.

SCHWARCZ, Lilia Moritz. Raça como negociação. Sobre teorias raciais em finais do século XIX no Brasil. In: FONSECA, Maria Nazaré Soares (Org.). Brasil afro-brasileiro. Belo Horizonte: Autêntica, 2000. p.11-40.

SCHWARTZ, Stuart B. Cantos e quilombos numa conspiração de escravos Haussás. Bahia, 1814. In: REIS, João José; GOMES, Flávio dos Santos (Orgs.). Liberdade por um fio: História dos quilombos no Brasil. São Paulo: Companhia das Letras, 1996. p.373-406.

SILVA, Aracy Lopes da. Mito, razão, história e sociedade: interrelações nos universos socioculturais indígenas. In: SILVA, Aracy Lopes da; GRUPIONI, Luís Donisete Benzi. A temática 
indígena na escola. Novos subsídios para professores de $1^{\circ}$ e $2^{\circ}$ graus. São Paulo: UNESCO/MEC, 1995. p.317-335.

SILVEIRA, Renato da. Os selvagens e a massa: papel do racismo científico na montagem da hegemonia ocidental. Revista Afro-Asia do Centro de Estudos Afro-Orientais - CEAO/UFBA, Salvador, n. 23, p. 84-145, 1999.

SIQUEIRA, Maria de Lourdes. Ago Ago Lonan. Belo Horizonte: Mazza, 1998.

UNICEF - Fundo das Nações Unidas para a Infância. Site institucional. Disponível em: http://www.Unicef.org/brazil/sessão_extratosefinal.htm> Acesso em: 13 nov. 2004.

VASCONCELLOS, Maria José Esteves de. Pensamento Sistêmico. O novo paradigma da ciência. Campinas, SP: Papirus, 2002. VERGER, Pierre. Orixás. São Paulo: Corrupio, 1981. 



\section{BIBLIOGRAFIA RECOMENDADA}

AB'SÁBER, Aziz Nacib. Incursões à pré-história da América tropical. In: MOTA, Carlos Guilherme (Org.). Viagem incompleta. (1500-2000). Formação: histórias. A experiência brasileira. 2. ed. São Paulo: SENAC, 2000.

ALMEIDA, Antônio Milton Oliveira. O borižonte da recep̧ão: os laços entre o espectador e a imagem midiática. 1998. Dissertação (Mestrado em Comunicação e Cultura Contemporâneas) - Universidade Federal da Bahia, Salvador, 1998.

ALVES, Rubem. Filosofia da Ciência. São Paulo: Ars Poética, 1996. ANDRÉ, Marli Eliza D. A. Etnografia da prática escolar. Campinas, SP: Papirus, 1995.

- O papel da pesquisa na formação e na prática dos professores. Campinas, SP: Papirus, 2001.

ARAÚJO, Ubiratan Castro de. A guerra da Babia. Série Capítulos. Salvador: Centro de Estudos Afro-Orientais (CEAO), 2001. . Reparação moral, responsabilidade pública e direito à igualdade do cidadão negro no Brasil. Texto síntese de Seminário Racismo, Xenofobia e Intolerância. Salvador, 20 nov. 2000.

ARDOINO, Jacques. Prefácio e apresentação da edição francesa. In: BARBOSA, Gonçalves Joaquim. Multirreferencialidade nas ciências e na educaşão. São Carlos: EdUFSCar, 1998. 
AYOH'OMIDIRE, Félix. ÀKÒGB ÁDÙN. ABC da língua e civilização Iorubanas. Salvador: EDUFBA, 2003.

ARANHA, Maria Lúcia de Arruda; MARTINS, Maria Helena Pires. Filosofando: Introdução à Filosofia. 3. ed. São Paulo: Moderna, 2003.

ASSMAN, Hugo. Reencantar a educação: rumo à sociedade aprendente. 5.ed. Petrópolis, RJ: Vozes, 1998.

BARBIER, René. A escuta sensível na abordagem transversal. In: BARBOSA, Gonçalves Joaquim. Multirreferencialidade nas ciências e na educação. São Carlos: EdUFSCar, 1998.

BARBOSA, Elyana. Espaço-tempo e poder-saber: uma nova epistéme? (Foucault e Bachelard). Disponível em: < http:/ / www.fflch.usp.br/sociologia/revistas/tempo-social/v71e21yana7.html> Acesso em: 07 jun. 2004.

BARBOSA, Gonçalves Joaquim. Multirreferencialidade nas ciências e na educação. São Carlos: EdUFSCar, 1998.

BECKER, Fernando. A epistemologia do professor: o cotidiano da escola. 3.ed. Petrópolis, RJ: Vozes, 1993.

BELLO, Ângela Ales. Fenomenologia e Ciências Humanas. Trad. Miguel Mahfoud e Marina Massini. Bauru, SP: EDUSC, 2004. BLOCH, R. Howard. Misoginia Medieval e a invenção do amor romântico ocidental. Tradução de Claudia Moraes. Rio de Janeiro: Ed. 34, 1995.

BURKE, Peter. A escrita da História: novas perspectivas. São Paulo: Editora Universitária Estadual Paulista, 1992.

CANDOMBLÉ na Bahia. Disponível em: <http://ajagunacultura.sites.uol.com.br> Acesso em: 30 abr. 2004.

CAVALLEIRO, Eliane. Racismo e anti-racismo na educação: repensando nossa escola. São Paulo: Summus, 2001. 
CHALMERS, Alan F. O que é ciência, afinal? Tradução Raul Fiker. São Paulo: Brasiliense, 1993.

CHAUÍ, Marilena. O discurso competente. In: . Cultura e democracia: o discurso competente e outras falas. 8.ed. São Paulo: Cortez, 2000. p. 3-13.

CHAVES, Eduardo O.C. Um esboģo de Filosofia analítica da Educação. Disponível em: <www.chaves.com.br/TEXTSELF/PHILOS/ esboço.htm> Acesso em: 23 maio 2003.

CRUZ, Eduardo Rodrigues da. A persistência dos deuses. Religião, cultura e natureza. São Paulo: UNESP, 2004.

DaMATTA, Roberto. Relativizando: uma introdução à antropologia social. 6. ed. Rio de Janeiro: Rocco, 2000.

DARTIGUES, André. O que é a Fenomenologia? 8. ed. São Paulo: Centauro, 2002.

DEL PRIORE, Mary (Org.). História da criança no Brasil. 4.ed. São Paulo: Contexto, 1996. (Coleção Caminhos da História).

FREIRE, Paulo et al. Na escola que fazemos: uma reflexão interdisciplinar em educação popular. São Paulo: Vozes, 1988. FURET, François. A oficina da História. Lisboa: Gradiva, 1967.

GADOTTI, Moacir. Dialética do amor paterno. 6. ed. São Paulo: Cortez, 2003.

GALEFFI, Dante Augusto. O ser-sendo da Filosofia. Salvador: EDUFBA, 2001.

. Tensões filosóficas contemporâneas: uma descrição em perspectiva. Ágere - Revista de Educação e Cultura, Salvador, v.6. n.6, 2002.

GIROUX, Henry. Os professores como intelectuais: rumo a uma Pedagogia crítica da aprendizagem. Porto Alegre: Artmed, 1988. 
GOERGEN, Pedro. Pós-Modernidade, Ética e Educação. Polêmicas do nosso tempo. Campinas, SP: Autores Associados, 2001. GONZÁLEZ, Torres; ANTONIO, José. Educação e diversidade. Bases didáticas e organizativas. Porto Alegre: Artmed, 2002. HALL, Stuart. Identidades culturais na pós-modernidade. Tradução de Tomaz Tadeu e Guacira Louro. Rio de Janeiro: D\&A, 1997.

HELlER, Agnes. O cotidiano e a História. 2.ed. Rio de Janeiro: Paz e Terra, 1970.

HUIZINGA, Johan. Homo Ludens. O jogo como elemento da cultura. 5. ed. São Paulo: Perspectiva, 2004.

JAPIASSÚ, Hilton Ferreira. Introdução ao pensamento epistemológico. Rio de Janeiro: Imago, 1992. - As paixões da Ciência: estudo de História das Ciências. São Paulo: Letras \& Letras, 1991.

KI-ZERBO, Joseph. História da África negra - I. 3.ed. [s.1.]: Publicações Europa-América, 1966.

KNELLER, George. A ciência como atividade humana. Rio de Janeiro: Zahar, 1980.

KUTSCHERAUER, Hugo O. A ética do amante. Amar é a inteligência do viver. Salvador, BA: Arcádia, 2003.

LACERDA, Inês. Introdução à filosofia da ciência. Curitiba: URFP, 1993.

LARROSA, Jorge. Nietzssche e a educação. Belo Horizonte: Autênctica, 2004.

LIBÂNEO, João Batista. Fé. Rio de Janeiro: Jorge Zahar, 2004. (Coleção Filosofia - Passo-a-Passo. V.34).

LÜDKE, Menga et al. Pesquisa em Educação: abordagens qualitativas. São Paulo: EPD, 1986. 
LUNA, Sergio. O falso conflito entre tendências metodológicas. Cad. Pesq., São Paulo n.66, p.70-74, ago. 1988.

MACHADO, Vanda. Ilê Axé. Vivências e invenção pedagógica. As crianças do Opô Afonjá. Salvador: EDUFBA, 1999.

MARCÍLIO, Maria Luiza. A lenta construção dos direitos da criança brasileira. - século XX. Biblioteca virtual de Direitos Humanos da Universidade de São Paulo. Comissão de Direitos Humanos. Disponível em: < direitoshumanos@usp.br> Atualizado em 28.09.1998. Acesso em: 13 jul. 2004.

MATUI, Jiron. Construtivismo: teoria construtivista sócio-histórica aplicada ao ensino. São Paulo: Moderna, 1995.

MERLEAU-PONTY, Maurice. Fenomenologia da percepção. Tradução de Carlos Alberto Ribeiro de Moura. 2. ed. São Paulo: Martins Fontes, 1999.

MINAYO, Maria Cecília de Souza et al. Pesquisa social: teoria, método e criatividade. 7.ed. Petrópolis, RJ: Vozes, 1997.

MONDIM, Batista. O homem, quem é ele? Elementos de Antropologia Filosófica. Tradução de Leal Ferreira. São Paulo: Paulus, 1980.

MONTEIRO, Silas Borges; SPELLER, Paulo. Formação docente e as questões da pós-modernidade. Maio 2004. Disponível em: $<$ http:www.ufmt.Br/revista/arquivo/ rev13form_docente_e_as_quest.html> Acesso em: 20 maio 2004.

MORIN, Edgar. Ciência com consciência. Rio de Janeiro: Bertrand Brasil, 1996.

- O método: O conhecimento do conhecimento. Porto Alegre: Sulina, 1999. - A cabeça bem feita: repensar a reforma, reformar o pensamento. Rio de Janeiro: Bertrand Brasil, 2000. 
Brasil, 2002.

- Amor, Poesia, Sabedoria. 4. ed. Rio de Janeiro: Bertrand

; KERN, Anne Brigitt. Terra pátria. Porto Alegre: Sulina, 2000 .

NIETZSCHE, Friedrich Willelm. Ecce Homo. De como a gente se torna o que a gente é. Tradução de Marcelo Backes. Porto Alegre: L\&PM, 2003.

OLIVA, Albert. Epistemologia: a ciência em questão. 4. ed. Campinas: Papirus, 1990.

OLIVEIRA, Eduardo. Cosmovisão africana no Brasil: elementos para uma filosofia afrodescendente. Fortaleza: LCR, 2003.

OLIVEIRA, Rafael Soares de (Org.). Candomblé: diálogos fraternos contra a intolerância religiosa. Rio de Janeiro: DP\&A, 2003.

PARENTE, Sandra. Camaçari. Sua história, sua gente. Camaçari: Artset, 2002.

PEREIRA, Amauri Mendes. História e cultura afro-brasileira:

parâmetros e desafios. Disponível em < http:/ /

www.espacoacademico.com.br/o36epereira.htm $>$ Acesso em: 12 maio 2004.

PIAGET, Jean. Ensaio da lógica operatória. Porto Alegre: Globo, 1971.

- Gênese das estruturas lógicas e elementares. Rio de Janeiro:

Forense, 1972.

- A equilibração das estruturas cognitivas. Rio de Janeiro:

Zahar, 1976.

- Da lógica da criança à lógica do adolescente. São Paulo:

Pioneira, 1976.

- Epistemologia genética. Tradução de Álvaro Cabral. São

Paulo: Martins Fontes, 1990. 
. A psicologia da criança. 6. ed. São Paulo: Martins Fontes, 1990.

. Seis estudos de psicologia. Tradução de Maria Alice

Magalhães D'Amorim e Paulo Sérgio Lima Silva. 24. ed. Rio de Janeiro: Forense Universitária, 1999.

PINTO, Louis. Pierre Bourdien e a teoria do mundo social. Rio de Janeiro: FGV, 2000.

REVISTA Palmares em ação. Ano I, n. 1, ago./set. 2002. Publicação da Fundação Cultural Palmares.

REVISTA Palmares em Ação. Ano I, n. 2, out./dez. 2002.

Publicação da Fundação Cultural Palmares.

REVISTA o Correio da UNESCO.

História da África. Ano 12, n. 7, jul. 1984.

RIBEIRO, Darcy. O povo brasileiro. A formação e o sentido do Brasil. São Paulo: Companhia das Letras, 1995.

RODRIGUES, Maria Lúcia et al. Edgar Morin: em busca dos fundamentos perdidos. Textos sobre o Marxismo. Porto Alegre: Sulina, 2002.

SANTOS, Ana Katia Alves dos. Cidadania, prática da exclusão social e solidariedade. A-con-te/ cer jornal do programa de pós-graduação da FACED/UFBA. Ano I, n. 0, jan. 2004.

. (Re)significando a produção construtiva do conhecimento: da epistemologia genética à epistemologia da complexidade. Educaşão e formaşão do educador-REVISTA da FAEEBA, Salvador, v.12, n. 20, jul/dez 2003.

. Ciência da Educação na Babia: Infância Afrodescendente e Epistemologia Crítica no Ensino Fundamental. 2005. Dissertação (Mestrado em Educação) - Faculdade de Educação, Universidade Federal da Bahia, Salvador, 2005. 
SAVIANE, Dermeval et al. História e História da Educação: $\mathrm{O}$ debate teórico-metodológico atual. Campinas, SP: Autores Associados; HISTEDBR, 1998.

SEQUEIROS, Leandro. Educar para a solidariedade. Projeto didático para uma nova cultura de relações entre os povos. Tradução de Daisy Vaz de Moraes. Porto Alegre: Artmed, 2000.

SILVA, Ana Célia da. A discriminação do negro no livro didático. Salvador: EDUFBA, 2001.

- Por uma representação do social do negro mais próxima e familiar. Texto apostilado. Salvador, 2003.

SILVA, Jônatas Conceição da. Vozes quilombolas - uma poética brasileira. Salvador: EDUFBA e Ilê Aiyê, 2004.

SILVA, Tomáz Tadeu. Documentos de identidade: uma introdução às teorias críticas do currículo. Belo Horizonte: Autêntica, 1999. SODRÉ, Muniz. A identidade como valor. Claros e escuros: identidade, povo e mídia no Brasil. Petrópolis, RJ: Vozes, 1999. SOUZA, Neuza dos Santos. Tornar-se negro. Rio de Janeiro: Graal, 1983.

TAVARES, Luís Henrique Dias. História da Babia. 7. ed. São Paulo: Ática, 1981.

TREVISAN, Amarildo Luiz. Filosofia da educação. Mímesis e razão comunicativa. Ijuí, RJ: UNIJUÍ, 2000.

VIEIRA, Maria do Pilar de Araújo et al. A pesquisa em História. 2. ed. São Paulo: Ática, 1991.

VYGOTSKY, Lev Semyonovith. A formação social da mente. São Paulo: Martins Fontes, 1994.

- Pensamento e linguagem. Tradução de Jéferson Luiz

Camargo. São Paulo: Martins Fontes, 1987. 
YOUNG, Michael. O currículo do futuro. Da "nova sociologia da educação". Uma teoria crítica do aprendizado. São Paulo: Papirus, 2000.

XAVIER, Juarez Tadeu de Paula. Cultura Ioruba. Disponível em: $<$ http://www.humanizar.com.br/paginas/ioruba.htm> Acesso em: 01 jul. 2004. 



\section{GLOSSARIO}

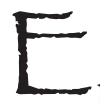

laborado com base nas obras consultadas durante a pesquisa de mestrado, principalmente no Dicionário de Relações Étnicas e Raciais, de Ellis Cashmore (2000).

Abiã - Aspirante à iniciação ao culto aos Orixás, mas já pertencente ao terreiro.

Afrodescendente - Definição atribuída, neste trabalho, ao sujeito que se identifica e preserva valores e princípios de tradição africana, seja na fase infantil, seja na idade adulta. A relação de parentesco, ancestralidade e etnia funda este conceito. Também chamado de afro-baiano ou afro-brasileiro. $\mathrm{Na}$ diáspora brasileira, especialmente na Bahia, encontram-se a maioria desses sujeitos, seja nos terreiros de Candomblé, seja no interior das muitas famílias negras que organizam este território.

Ancestrais - na Bahia são conhecidos como Orixás. Seres simbolicamente divinizados. Antepassados dos afrodescendentes, reconhecidos por sua função de intermediários entre o indivíduo, a família ou grupo que o representa e o Deus supremo no qual esses sujeitos acreditam. São parentes divinizados dos afrodescendentes.

Axé - Poder místico que rege o universo; força cósmica. Força vital que dá unidade às comunidades de tradição africana. Força que 
também pode estar presente em alguns objetos presentificados nos terreiros. Por isso, essa palavra relaciona-se também com as preparações rituais postas nos fundamentos de um espaço sagrado de tradição africana.

Candomblé - Espaço sagrado para os afrodescendentes. Importante instituição que se preocupa em assegurar a continuidade do processo civilizatório africano: sua cultura e religiosidade. Espaço que, para além da religião, significa opção sócio-política de identificação com uma cultura historicamente negada e discriminada pelo sistema colonial-escravista e reatualizada ainda hoje, no século XXI. Também conhecido como 'terreiro', este local apresenta, incorporado em sua vida cotidiana, valores e princípios, tais como: a reconciliação com a experiência africana, a solidariedade, o compartilhamento, o respeito à natureza, a diversidade, dentre outros.

Colonialismo - Do latim colônia. Significa cultivo (para terra nova). Pode-se afirmar que diz respeito a práticas de natureza imperialista, no qual um Estado busca manter soberania política sobre um território distante. Imperialismo (do latim imperium) significa comando, domínio, desejo de adquirir colônias e dependência de ordem políticas e também cultural. Sistema de poder e de relações de autoridade impostos e novos padrões de desigualdade envolvendo povos de diferentes línguas, nacionalidades, credos, cor, etc. (CASHMORE, 2000).

Diáspora - Palavra polissêmica, mas de usos relacionados. Foi extraída dos gregos antigos e etimologicamente deriva de dia (através, por meio de) e de speirõ (dispersão, disseminar ou dispersar). Dos vários enfoques, é utilizada neste trabalho como comunidade transnacional, ou seja, comunidade cujas redes políticas, sociais e econômicas atravessam as fronteiras das nações-estado, reconstruindo suas identidades culturais (povos que vêm de algum lugar, têm uma história e sofrem transformações). É o caso do afrodescendente na Bahia. 
Direito - Em sentido geral, diz respeito à técnica da coexistência humana. Dar a cada um o que lhe cabe na sociedade em relação aos bens, sejam eles materiais, espirituais, morais, físicos, econômicos. Como técnica, pode ser entendida como conjunto de regras (leis e normas) que visa o comportamento inter-subjetivo. As sociedades ocidentais se fundam também a partir dessa idéia (vide história de Roma Antiga e sua fundação). Faculdade legal de praticar ou não praticar um ato; o que é justo conforme a lei; conjunto de normas vigentes num país.

Discriminação - Expressão que indica comportamento racista e que objetiva negar aos membros de um determinado grupo acesso igualitário aos bens humanos produzidos. Favorece a exclusão desses grupos (ou indivíduos) da sociedade, fortalecedora da marginalização sócio-político-econômico e cultural. Além da racial, existem outros tipos de discriminação: a social, a sexual, a lingüística etc.

Ebômin - Filha-de-santo com sete anos ou mais de iniciação no culto aos Orixás.

Ekédi - Mães que acompanham as suas filhas-de-santo quando estão incorporadas pelos Orixás. Zeladora de Orixás. Orientadora dos bons caminhos.

Etnia - Conceito fundante de grupos culturais. Deriva do grego ethnikos, adjetivo de ethos, e significa grupo, povo, nação. Contemporaneamente, refere-se a um grupo que se solidariza, se reconhece e se identifica a partir dos mesmos valores, princípios e interesses comuns. Cada grupo étnico é uma agregação de pessoas unidas por experiências compartilhadas, sem que isso signifique isolamento entre si. Geralmente, os grupos étnicos compreendem a importância de dialogar com outros grupos étnicos.

Ilê - Casa construída não só de paredes, mas de pessoas que apresentam objetivos e princípios comuns. Espaço sagrado para 
os afrodescendentes; espaço de convívio, de trocas de experiências, de vida.

Intolerância - Postura que não admite manifestações de vida contrárias ou diferentes das suas. O intolerante, geralmente, é violento, física ou simbolicamente, e tenta negar a condição de humanidade do outro, suas preferências, suas crenças, seus costumes, seu posicionamento político etc. O intolerante parte, quase sempre, de posições de negação frente ao outro na sua diferença.

Minoria - Diz respeito a grupos culturais, socialmente ou economicamente negados, discriminados, excluídos historicamente e perseguidos por ideologias massacrantes. Minoria não no sentido populacional, nesse sentido são, em muitos casos, maioria ou de considerável número populacional. Notem-se os negros na Bahia, os índios na época da colonização e, hoje, os portadores de necessidades especiais, as mulheres etc.

Parentesco - Palavra definida por afinidade ou identificação e por descendência. Pode ser o modo como um ser humano se torna parente de um grupo. A descendência pode ser definida a partir de um ancestral masculino, feminino ou por ambos, com propósitos diferentes ou similares. Dois seres humanos são parentes por um ser descendente do outro ou quando são descendentes comuns de um mesmo ancestral. São parentes também quando crescem na mesma família que apresenta princípios organizacionais do mundo sócio-político.

Preconceito - Palavra originária do latim prae, e conceptu, conceito, que se define por um conjunto de valores e crenças aprendidos durante os processos educativos e sociais, de maneira ampla, e na maioria das vezes ocultamente, que fazem com que certos indivíduos ou grupos emitam opiniões ou se posicionem a favor ou contra outros indivíduos ou grupos, antes mesmos de se permitirem trocar experiências. O preconceito pode resultar em 
opiniões e posturas positivas ou negativas, no entanto sabe-se que o preconceito é sempre negativo em relação a raça, etnia, religião e a indivíduos em condição de pobreza. Criam-se posturas hostis e generalistas frente às condições citadas. A xenofobia está também relacionada ao preconceito: do grego xenos, para estranho, e phobia, para medo ou aversão, que significa medo do diferente, do estrangeiro. O que nos parece certo afirmar é que o ser humano não é naturalmente preconceituoso e xenofóbico. Essas são condições aprendidas via processos educativos na família, na escola, entre amigos, através da mídia, no trabalho etc.

Raça - Grupos de indivíduos cujas características se assemelham e são transmitidas via hereditariedade. $\mathrm{O}$ aspecto biológico torna-se importante nessa compreensão; origem comum. Indica uma mesma ascendência. Mas o termo, atualmente, é também usado de maneira diversa. Em alguns casos, articula-se à origem biológica às condições sociais, políticas e culturais a que estão submetidos esses grupos. Hoje é mais compreendido a partir de sua construção política e não mais pela dimensão biológica pura e simplesmente, já que o racismo continua fundando muitas sociedades mundo afora (particularmente o Brasil).

Religião - Do latim religio. Diz respeito à crença em forças que vão além dos limites impostos fisicamente ao ser humano. $\mathrm{O}$ ser humano reconhece-se, muitas vezes, limitado nas ações e decisões e a partir daí estabelece um vínculo com um ser supremo que o ajuda a caminhar nos espaços terrenos. Como existem várias religiões, cada uma acaba atribuindo uma explicação particular para si própria, o que lhe confere identidade.

Segregação - Pôr à margem, marginalizar. Existem dois tipos de segregação: a de fato e a de direito. A de direito é quando indivíduos ou grupos são separados pela lei, com base nas diferenças raciais ou étnicas. Ex: na Bahia, apenas na década de 70 do século 
passado, o Candomblé teve sua prática liberada; até então estava marginalizado, segregado dessa sociedade. A segregação de fato é aquela que não apresenta aparato legal para existir, mas que ainda assim se faz presente no cotidiano dos indivíduos.

Xirê - roda realizada pelos "filhos de santo", na qual há uma seqüência de cânticos cantados para os orixás. 
ANEXO A

\section{Mitologla AFro-BraSILEIRA $A^{18}$ A ORIGEM DO MUNDO}

Contam os ancestrais que Olorum (Deus) deu origem ao mundo. Durante quatro dias criou um Odu (destino) e um gigantesco planeta, formado apenas de água.

Mas Olorum notou que esse mundo criado ainda precisava de novos detalhes e, assumindo sua limitação, por não ser absoluto, convidou Oxalá e Obatalá (orixás antigos e poderosos) e os informou que apenas um deles seria indicado para a realização de uma importante missão.

Oxalá foi o escolhido, era o mais velho. Olorum, então, entregou-lhe, numa sacola de tecido branco, um pó preto, um caramujo, um camaleão e uma galinha de três patas. O orixá que não foi escolhido (Obatalá) ficou muito zangado e começou a arquitetar um plano para roubar de Oxalá o poder de ajudar Olorum na criação.

Elegbara (mais conhecido como Exu, confundido com o diabo cristão) foi chamado por Obatalá para armarem um plano contra Oxalá. Elegbara, que também tem poderes sobre o espaço e o tempo, 
resolveu plantar entre o Orum (céu) e a Terra uma grande palmeira, que num instante transformou-se numa árvore adulta. Exu pediu ao sol que brilhasse sobre essa árvore com toda a sua força.

O calor insuportável fez com que Oxalá sentisse sede. Ao avistar a árvore no meio do caminho, pensou em retirar seu líquido para saciar a sua sede. E assim o fez, com o seu cajado perfurou a palmeira e dela bebeu o seu líquido. Instantes depois, Oxalá dormiu embriagado.

Foi assim que Obatalá tomou de Oxalá tudo o que Olorum havia lhe dado para terminar a criação. Obatalá então derramou o pó preto sobre a água do planeta. Mas, o curioso é que a quantidade do pozinho preto não afundou. Foi aí que, ao ver o montinho de terra, a galinha de três patas tratou de ciscar a terra, ação que desencadeou o surgimento dos continentes e o camaleão, ao andar sobre a terra, tornou-a sólida e imperfeita (surgindo montes, vales...). O caramujo, rastejando, criou o leito dos rios, lagoas, lagos...

Foi tudo tão maravilhoso que Obatalá voltou ao Orum para contar a Olorum que o responsável por tudo aquilo era ele. Segundo ele, a criação do mundo dependeu de suas façanhas. De fato, Olorum ficou maravilhado com o mundo criado. Afinal sua criação tinha sido terminada. Mas Olorum gostava muito de Oxalá e não queria vê-lo triste. Por isso, resolveu lhe dar outra responsabilidade: a criação dos seres humanos que iram habitar aquele mundo.

Oxalá tomou então os seres humanos como uma de suas maiores responsabilidades. Mas, como criaria esses seres? Foi aí que ele pensou em pedir ajuda a Nana Buruku (orixá velho e, segundo contam, esposa de Oxalá). Por ser senhora dos pântanos (água e terra são seus elementos, ou seja a lama), Nana deu a idéia a Oxalá de criar o ser humano com o barro que ela possuía. E assim se fez. E o ser humano foi criado... 
1 Dado extraído de minha Dissertação de Mestrado intitulada "Ciência da Educação na Bahia: Infância Afrodescendente e Epistemologia Crítica no Ensino Fundamental" (Biblioteca da Universidade Federal da Bahia).

2 Segundo Vasconcelos (2002), o conceito de Epistemologia passou por transformações, dentre as quais destacam-se três momentos. 1. Inicialmente, a palavra Epistemologia era considerada sinônimo de Teoria do Conhecimento. Ela se ocupava da natureza e do alcance do conhecimento científico, em oposição ao conhecimento vulgar. Suas questões eram: Como se pode conhecer o mundo cientificamente? Em que se distingue o conhecimento obtido por um cientista do conhecimento de um leigo? Considerava que a maneira de conhecer cientificamente o objeto é condicionada pela concepção que se tem do mesmo objeto. Então, nesse sentido, admitia-se que subjacente à Epistemologia estava a ontologia, que se ocupava dos estudos sobre a natureza ou a "essência do ser" a ser conhecido. 2. No segundo momento de transformação do conceito, associa-se ao Círculo de Viena, reunião de importante filósofos e estudiosos do início do século XX. Eles consideravam que as proposições científicas refletem de maneira especular o mundo. Conhecida como "Filosofia Analítica”, deveria indicar como alcançar as proposições verdadeiras sobre o mundo natural. Então, nesse período (início do século $\mathrm{XX}$ ), a Epistemologia ficou reduzida à análise da linguagem da ciência. 3. Finalmente, com a evolução do conceito, há um renascimento da Epistemologia como Filosofia da Ciência, deixando de ser Filosofia da Linguagem da Ciência. Ela passa a propor vários problemas ou aspectos da ciência e passa a ter diversos ramos: teoria do conhecimento, metodologia da ciência, semântica da ciência, lógica da ciência, ontologia da ciência, axiologia (estudo dos valores) da ciência, ética da ciência. Neste nosso texto, destacam-se, principalmente, os ramos: teoria do conhecimento, axiologia, ética e ontologia na ciência da educação (Pedagogia).

3 Conceito apresentado por Pierre Bourdieu (2001). 
4 Sobre religiosidade africana e afro-brasileira (e seus mitos), muito já se tem produzido. Por isso, é desnecessária a repetição dessa discussão nesta obra. Minha intenção é discutir a tradição africana a partir de uma compreensão epistemológica e ontológica o que, nesse sentido, a torna autêntica.

5 Apesar de advertir os leitores no sentido de não acreditarem em coisas por ele não ditas-escritas, é impossível essa tarefa quando se realiza leitura de natureza crítica. Perceber a dimensão oculta, não explícita em sua teorização, nem por isso menos presente, é ação, em nosso caso específico, impossível de evitar.

6 Assumimos aqui a discussão inicial da história brasileira a partir da descoberta do Novo Mundo, por ser o processo de colonização o nosso foco. Não desconsideramos, no entanto, a pré-história brasileira no sentido de considerar os povos que aqui já habitavam, de procedência asiática (paleoíndios do leste asiático). Sobre a análise, cf. Mota (2000).

7 Assumimos o termo minorias numa referência à exclusão social historicamente construída para os índios, negros e mestiços.

8 Para maior aprofundamento sobre mitologia e religiosidade na diáspora baianabrasileira, consultar obras citadas e mais: Prandi (2001).

9 Para conhecer as histórias míticas de cada orixá, cf. Siqueira (1998) e Luz (2000).

10 A linearidade e a ordenação como organizadoras da razão moderna são alvos de críticas contundentes feitas por Heidegger à metafísica ocidental. Em Ser e Tempo (HEIDEGGER, 2002) é possível compreender a sua preocupação com o lugar do ser pensante, partindo da crítica à metafísica moderna e abrindo veredas antes não pensadas no campo da fenomenologia e da hermenêutica.

11 As diferentes categorias de artistas e escritores de uma determinada época e sociedade.

12 Orixá que durante seis meses é homem e nos outros seis meses é mulher, chamandose Bessém. É conhecido como orixá da Terra, representa as riquezas escondidas no subsolo, mas também desempenha a função de levar a água de volta ao palácio de Xangô, no céu, e para que essa água chegue com a mesma pureza e quantidade iniciais, ele desenvolve a tarefa de modo organizado, cuidadoso, paciente, metódico. Neste sentido, é rigoroso porque deseja, quer alcançar, tem uma meta que deseja cumprir da melhor forma. No entanto, Oxumaré, apesar da preocupação em ser rigoroso e metódico na entrega das águas, não perde a delicadeza, cuidando para que os elementos naturais que encontra no caminho até o céu não sejam prejudicados com a sua trajetória, tais como os ventos, as nuvens, os pássaros. Mais informações sobre esse orixá, ver obras indicadas nas referências, a exemplo do livro de Marco Aurélio Luz.

13 Quem tem a força da tradição afrodescendente (e dos Orixás) e pratica a religião. 
14 Nome preconceituosamente dado à religiosidade de tradição africana.

15 Segundo grande parte dos estudiosos, a modernidade compreende os séculos XV a XVIII, tendo início com o renascimento cultural e a expansão comercial e marítima européia, "terminando" com a revolução francesa. A modernidade realiza grandes transformações no interior da cultura, da filosofia e da ciência, principalmente.

16 Não estamos, com este discurso, deixando de lado o papel da escola como espaço viabilizador de desenvolvimento de competências e habilidades formais (ler, escrever, raciocinar...), mas ela não pode ser só isso, já que é também espaço de convivência humana.

17 Para conhecer todas as histórias da mitologia afro-brasileira, consultar obra de Reginaldo Prandi (2001). 
Este livro foi publicado no formato $155 \times 215 \mathrm{~mm}$, Tipologia: Garamond, Papyrus, Arial, Myriade Roman, Viner Hand ITC Impresso no Setor de Reprografia da EDUFBA Acabamento e impressão Gráfica Bureau 